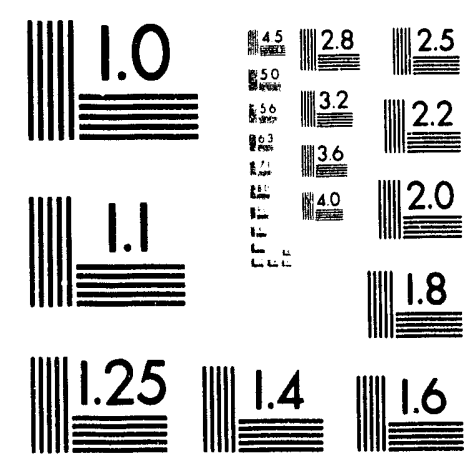



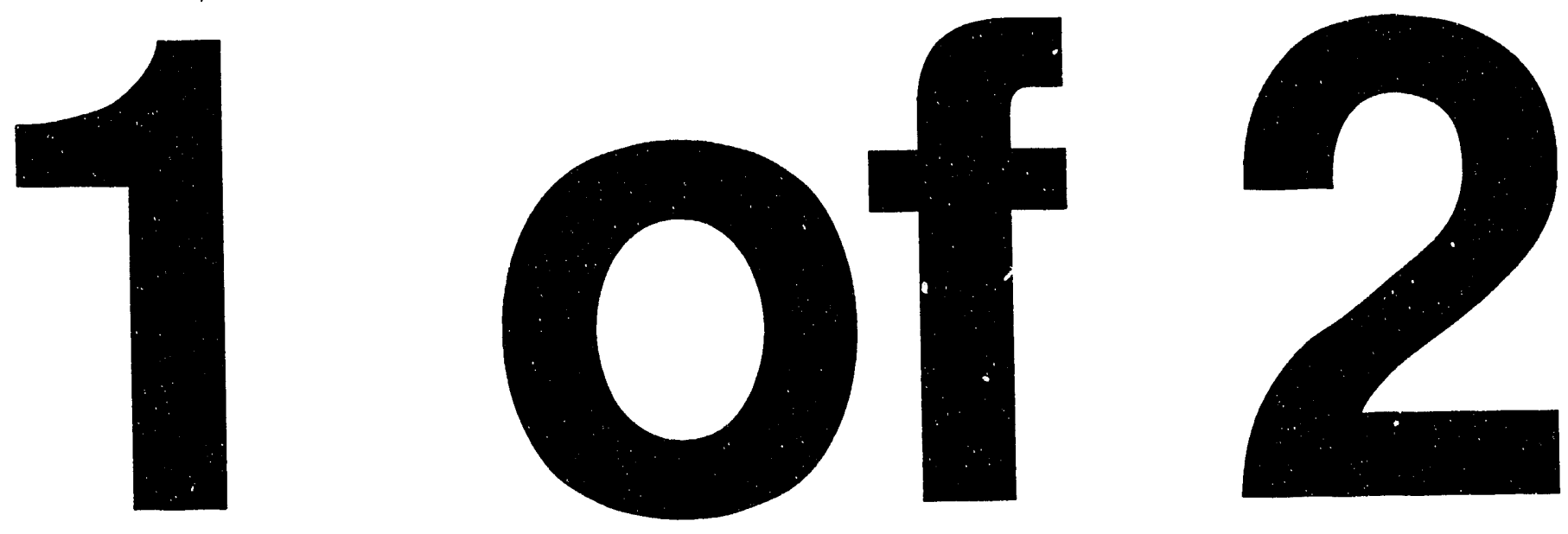
DOE/EIA-0293(93)

Distribution Category UC-950

\title{
Directory of Energy Information Administration Models 1993
}

July 1993

\author{
Energy Information Administration \\ Office of Statistical Standards \\ U.S. Department of Energy \\ Washington, DC 20585
}

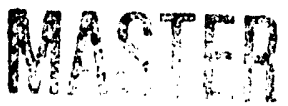

DISTRIBUTION OF THIS DOCUMENT IS UNLIMITED

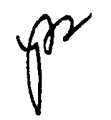

This report was prepared by the Energy Information Administration, the independent statistical and analytical agency within the Department of Energy. The information contained herein should not be construed as advocating or reflecting any policy position of the Department of Energy or any other organization. 


\section{Preface}

This directory revises and updates the Directory of Energy Infonnation Administration Models 1992, DOE/EIA-0293(92), Energy Information Administration (EIA), U.S. Department of Energy, June 1992. The following models which were in the last Directoryare no longer being used by EIA and have been inactivated: C.APSTOCK. Capital Stock Model; DCEM, Drilling Cost Estimates Model; DEMS, Demand Evaluation Modeling System Integrating Module; INM, International Nuclear Model; STIM, Short-Term Integrating Model; and UDAPAS, Unified Demand and Price Analysis Subsystem. New models in use by EIA include the DRI, Data Resources, Inc. Model of the U.S. Economy, a proprietary model; GASCAP, Wellhead Gas Productive Capacity Model; LIIIEAP, Low Income Household Energy Assistance Program; and the PCINM, International Nuclear Model - Personal Computer. The model descriptions for the PCINM, International Nuclear Model - Personal Computer, and the STIFS, Short-Term Integrating Forecasting System were updated according to revised documentation approved during the past year.

Publication of this directory is supported by Public Law 93-275, Federal Energy Administration Act of 1974, Section 57(B)(1) (as amended by Public Law 94-385), Energy Conservation and Production Act, which states in part,

...that adequate documentation for all statistical and forecast reports prepared...is made available to the public at the time of publication of such reports.

With respect to its modeling efforts, EIA issued the following standards in 1991: Standard 91-01-01, Model Acceptance; Standard 91-01-02, Active Model Inventory Requirements; Standard 91-01-03, Model Documentation; and Standard 9101-04, Model Archival. In 1992, Standard 92-01-05, Proprietary Models, which describes the necessary actions governing the use of proprietary modeis (i.e., models available to EIA through license, purchase, or subscription) in EIA reports and modeling systems was issued.

This directory contains descriptions about each model, including the (itle, acronym, purpose, followed by more detailed information on characteristics, uses, and requirements. Sources for additional information are identified. Included in this directory are 35 EIA models active as of May 1, 1993. Models that run on personal computers are identified by "PC" as part of the acronym.

Appendix A identifies major EIA modeling systems and the models within these systems. Appendix B is a summary of the Annual Energy Outlook Forecasting System.

EIA is developing new models, a National Energy Modeling System (NEMS), and is making changes to existing models to include new technologies, environmental issues, conservation, and renewables, as well as to extend forecast horizon. Other parts of the Department are involved in this modeling effort. A fully operational model is planned which will integrate completed segments of NEMS for its first official application--preparation of EIA's Annual Energy Outlook 1994. Abstracts for the new models will be included in next year's version of this directory. 


\section{Contents}

Models of the Energy Information Administration

Page

Building Energy End-Use Model (BEEM) . . . . . . . . . . . . . . . . . . . 1

Coal Supply and Transportation Model (CSTM) . . . . . . . . . . . . . . . . . . . . 3

Data Resources Inc. Model of the U.S. Economy (DRI) . . . . . . . . . . . . . . . . . 5

Electricity Market Model (EMM) . . . . . . . . . . . . . . . . . 6

Gas Analysis Modeling Systetn (GAMS) . . . . . . . . . . . . . . . . . . . . . . . . 9

Industrial Model (IM) . . . . . . . . . . . . . . . . . . . . . . . . . . 13

Intermediate Future Forecasting System (IFFS) . . . . . . . . . . . . . . . . . . . . 14

International Coal Trade Model (ICTM) . . . . . . . . . . . . . . . . . . . . . . 17

International Nuclear Model - Personal Computer (PCINM) . . . . . . . . . . . . . . . . 20

Levelized Nuclear Fuel Cycle Cost Model (LNFCC.PC) . . . . . . . . . . . . . . . . . . 22

Low Income Household Energy Assistance Program (LlliEAP) . . . . . . . . . . . . . . 23

Market Penetration Model for Active and Passive Solar Technologies (MPSOLAR-PC) . . . . 24

Market Pene'ration Model for Ground Water Heat Pump Systems (MPGWHP-PC) . . . . . . . 26

Market Penetration Model for Residential Rooftop Photovoltaic Systems (MPRESPV-PC) . . . 28

Mini-Macroeconomic Personal Computer Model (PCMAC) . . . . . . . . . . . . . . . . 29

National Coal Model $(\mathrm{NCM})$. . . . . . . . . . . . . . . . . . . . . . . . . . . 31

National Utility Financial Statement Model (NUTS) . . . . . . . . . . . . . . . . . . . 34

Nonutility Generation Supply Model (NUGS) . . . . . . . . . . . . . . . . . . . . . . 37

Oil Market Module $(\mathrm{OMM})$. . . . . . . . . . . . . . . . . . . . . . . . . . . . . . 39

Oil Market Simulation Model (OMS-PC) . . . . . . . . . . . . . . . . . 40

Petroleum Financial Analysis System (PETFAS-PC) . . . . . . . . . . . . . . . 42

Production of Onshore Lower 48 Oil and Gas Modell (PROLOG) . . . . . . . . . . . . . . . 44

Refinery Evaluation Modeling System (REMS) . . . . . . . . . . . . . . . . . . . . 48

Refinery Yield Model Spreadsheet Systern (RYMSS-PC) . . . . . . . . . . . . . . . . 56

Residential Energy End-Use Demand Model (REEM) . . . . . . . . . . . . . . . . . . 59

Resource Allocation and Mine Costing Model (RAMC) . . . . . . . . . . . . . . . . . . 61

Revenue Requirements Modeling System (RRMS) . . . . . . . . . . . . . . . . . . . 66

Short-Term Coal Analysis System (SCOAL) . . . . . . . . . . . . . . . . . . . . 68

Short-Tern Integrated Forecasting System (STIFS) . . . . . . . . . . . . . . . . . 71

Short-Term Nuclear Annual Power Production Simulation (SNAPPS) . . . . . . . . . . . . 76

Transportation Energy Demand Model (TED) . . . . . . . . . . . . . . . . . 78

Uranium Market Model (UMM-PC) . . . . . . . . . . . . . . . . . . . . . . 79

Wellhead Gas Productive Capacity Model (GASCAP) . . . . . . . . . . . . . . . . . . . 81

World Energy Projection System (WEPS-PC) . . . . . . . . . . . . . . . . . . . 83

World Integrated Nuclear Evaluation System (WINES-PC) . . . . . . . . . . . . . . . . 85

Appendix A - Major Modeling Systems and Contributing Models . . . . . . . . . . . . . 91

Appendix B - AEO 93 Forecasting System _ . . . . . . . . . . . . . . . . . . . . 95 


\section{Models of the Energy Information Administration}

\section{Building Energy End-Use Model (BEEM)}

Description: BEEM is designed to forecast energy consumption in commercial buildings in the United States on an annual basis through the year 2010 . The level of detail in BEEM includes three major fuels (electricity, natural gas, and distillate fuel oil) and five minor fuels (residual fuel oil, liquefied petroleum gas, coal, motor gasoline, and kerosene). These fuels are modeled at the four Census region levels.

Last Model Update: September 1991.

Part of Another Model? Intermediate Future Forecasting System.

Model Interfaces: Input data are fed in from IFFS integrating model; Output data are subınitted to IFFS.

\section{Sponsor:}

- Office: Office of Integrated Analysis and Forecasting

- Division: Energy Demand and Integration Division

- Branch: Energy Demand Analysis Branch, ĖI-813

- Model Contact: Moháıninad Adra

- Telephone: $202-586-6580$

Documentation: Energy Information Administration, $P C$ AEO Forecasting Model for the Annual Energy Outlook 1990, Model Documentation (Section 3, Commercial Energy Demand), DOE/EIA-M036(90) (Washington, DC, March 1990) and technical notes.

Archive Media and Installation Manual(s): Archived as part of IFFS93.

Purpose: BEEM provides long-term projections of commercial energy consumption for the Annual Energy Outlook.

Energy System Described by Model: Commercial sector energy use.

Coverage:

- Geographic: Four Census regions: Northeast, Midwest, South, West
- Time Unit/Frequency: Annual, 1987 through 2010

- Product(s): Electricity, natural gas, distillate, residual oil, liquefied petroleum gas, coal, motor gasoline, and kerosene

- Economic Sector(s): Seven Building Categories: Warehouse, Retail/Wholesale, Office, Food Sales/Service, Education, Continuous Use, Miscellaneous. Six End-Use Categories: Heating, Cooling, Water Heating, Cooking, Lighting, and Other.

Modeling Features:

- Model Structure: Recursive by fuel and Censusregion

- Modeling Technique: End-use simulation model, some parameters estimated econometrically. Nonresidential Buildings Energy Consumption Survey data are used for initial conditions and engineering analysis for efficiency estimates.

- Special Features: None.

Non-DOE Input Sources:

- Data Resources, Inc., Control Simulation of the Commercial Model, July 1989.

- Civilian employment forecasts for two macroeconomic cases.

- Lawrence Berkeley Laboratories, Economics of Efficiency Improvement in Residential Appliances and Space Conditioning Equipment, September 1985.

- Life of equipment (heating, cooling, and water heating)

- New technology efficiencies (initial 1986: water heating)

- GRI, Topical Report \# 1: Data Enhancements for Commencial Sector Analysis of GRI Baseline Modeling Systems, July 1987.

- New technology efficiencies (initial 1986), capital costs for new equipment (regional adjustments', and operating and maintenance costs for new equipment: heating and cooling 
- Electric Power Research Institute, the COMMLND Computer Program 3.0 Input Datasets.

- Capital costs for new equipment (heating, cooling and water heating

- Air Conditioning and Refrigeration Institute, Unitary Directory, August 1989 - January 1990.

- Capital costs for new equipment (heating and cooling).

\section{DOE Data Input Sources:}

Forms and Publications:

- Energy Information Administration, Nonresidential Buildings Energy Consumption Survey (NBECS): Commercial Buildings Consumption and Expenditures 1986, DOE/EIA-0318(89), (Washington, DC, May 1989)

- New additions to floorspace (initial 1986)

- Energy intensity in new buildings

- Energy use in existing buildings

- Existing and new equipment consumption fuel shares (initial 1986)

- Energy Information Administration, "Inputs to Commercial Models Calibrated to 1986 NBECS," Memorandum (August 16, 1989) to John Pearson from Miriam Goldberg.

- Energy use intensity in new and existing buildings

- Existing and new equipment consumption fuel shares (initial 1986)

- Energy Information Administration, State Energy Data Report, Consumption Estimates, 1960 - 1990, DOE/EIA-0214(90), (Washington, DC, May, 1992)

- Benchmark consumption (1989 - 1990)

- Energy Information Administration, Shon-Term Energy Outlook, DOE/EIA-0202, (Washington, DC, Published Quarterly).

- Benchmark consumption (1991 - 1993)

- Energy Information Administration, Ronald J. Sutherland and Henry Clarius, "The Demand for Energy in Commercial Buildings: An Analysis Using NBECS Data," September 1989
- Piice and employment elasticities

- Conservation and Renewable Energy, Technical Support Document: In Support of Interim Energy Conservation Standards, Vol. 2, DOE/CE-0223, (Washington, DC, June 1988)

- New technology efficiencies (initial 1986: water heating).

Models and Other:

- Energy Information Administration, Intermediate Future Forecasting System.

- Energy prices

- Civilian employment

- Energy Information Administration, Office of Integrated Analysis and Forecasting, Energy Demand and Integration Division.

- Prices and macroeconomic assumptions for adjusting civilian employment forecasts

- Estimates of market shares for new technologies.

General Output Descriptions: Consumption forecasts are generated for electricity, natural gas, and distillate. In addition, residual fuel, liquefied petroleum gas, coal, motor gasoline, and kerosene are projected.

Computing Environment:

- Hardware Used: IBM 3084QX

- Operating System: MVS/XA

- Language/Software Used: IBM FORTRAN, Version 1.0

- Memory Requirement: 300 Kilobytes (Kb)

- Storage Requirement: 150 tracks of an IBM 3380 disk pack

- Estimated Run Time: 17 minutes in an integrated mode on an IBM $3084 Q X$

- Special Features: None.

Independent Reviews Conducted: Independent Expert Review by Eric Hurst and Russell Lee of Oak Ridge National Laboratory, June 1991.

Status of Evaluation Efforts by Sponsor: None. 


\section{Coal Supply and Transportation Model (CSTM)}

Description: CSTM is a freight network equilibrium model adapted to forecast U.S. coal supply and distribution patterns at a moderately disaggregated level of detail. The problem solved by the CSTM is to meet a set of fixed demands for different coal types in different economic sectors and regions by producing from supplies of different coal types in different supply regions and by shipping these supplies across a transportation network.

Last Model Update: October 1991.

Part of Another Model? Intermediate Future Forecasting System (IFFS)

\section{Model Interfaces:}

- National Coal Model (NCM)

- CSTM supplies coal transportation costs and receives lists of coal types from which each demand job may be satisfied.

- Reserve Allocation and Mine Costing Model(RAMC)

- CSTM receives supply curves and mine retirement data which deternine minemouth prices in the model.

- International Coal Trade Model (ICTM)

- CSTM receives export demand data in trillion Btu/year.

- Intermediate Future Forecasting System (IFFS)

- CSTM supplies minemouth, transportation and delivered coal prices by sector and region.

Sponsor:

- Office: Office of Integrated Analysis and Forecasting

- Division: Energy Supply and Conversion Division

- Branch: Coal, Uranium and Renewable Fuels Analysis Branch, EI-822

- Model Contact: Richard Newcombe

- Telephone: 202-586-2415

\section{Documentation:}

- Energy Information Administration, Coal Supply and Transportation Model (CSTM) Model Documentation, DOE/EIA-M048, (Washington, DC, November 1991)
- Energy Information Administration, Coal Supply and Transponation Model, Model Description, DOE/EIAM022, (Washington, DC, June 1987)

- Energy Information Administration, Coal Supply and Transportation Model, User Model, DOE/EIA-M010, (Washington, DC, July 1985)

- Energy Information Administration, Coal Supply and Transponation Model, Executive Summaiy, DOE/EIA0401 (EXEC), (Washington, DC, August 1983)

- Energy Information Administration, Coal Supply and Transponation Model, Model Description and Data Documentation, DOE/EIA-0401, (Washington, DC, August 1983).

Archive Media and Installation Manual(s):

- CSTMSA91 - Archived (stand-alone version) as used in the International Future Forecasting System, 1991.

Purpose: CSTM is used to forecast annual coal supply and distribution to domestic and foreign markets.

Energy System Described by Model: U.S. coal production, national and international coal transportation industries.

\section{Coverage:}

- Geographic: United States, excluding Hawaii, Puerto Rico and Island Territories.

- Time Unit/Frequency: Annual forecasts through 2010.

- Product(s): Bituminous steam and coking coals, subbituminous and lignitic steam coals.

- Economic Sector(s): Forecasts coal supply to Residential/Commercial, 3 Industrial, 2 Metallurgical, 3 Export and 31 Electric Utility demand sectors in 44 domestic, 4 foreign demand regions.

\section{Modeling Features:}

- Model Structure: The model uses 409 coal supply curves representing 54 types of coal produced in 32 supply regions. Shipments are made over a network of 755 rail and water arcs or links to simulate coal transportation from the mine to consumers representing demand from 31 electric utility and 9 nonutility subsectors in $\mathbf{4 4}$ domestic and 4 overseas demand regions. A single model run represents a single year, but up to 26 consecutive years may be run in an iterative fashion.

- Modeling Technique: The model develops a disaggregated demand list from IFFS, National Coal Model and International Coal Model input, for a total of about $\mathbf{4 0 0}$ distinct sectoral-regional demands, or $d e$ mand jobs. Least-cost coal transport routes from 
every supply region to each demand center for each demand job are identified by a shortest path algorithm. Minemouth costs are then added to each least cost coal transport route, and a heuristic equilibrium assignment algorithm is used to shift fracticiss of demand toward lower cost supply source/transport route combinations, called participants. The second algorithm is required since both mining cost and transport cost vary directly as a function of volume mined/shipped. The model iterates the shortest path algorithm after recosting the transportation routes and repeats the heuristic participation shifting algorithm until convergence criteria for the equality of delivered costs from all sources for each demand job are met.

\section{- Special Features:}

- All demands are exogenous to CSTM.

- Supply curves depicting coal reserve base are exogenous to CSTM.

- CSTM provides moderately detailed depiction of coal shipments over hundreds of uni- and multimodal routes from mining regions to coal demand regions in the United States, Europe, and the Orient.

- CSTM may be run to produce aggregated output for IFFS national energy modeling system, or in stand-alone mode for more detailed studies.

- CSTM reports minemouth, transport and delivered coal prices, coal shipment origins, destinations, shipment routes, Btu and sulfur levels, and detailed sectoral distribution.

\section{Non-DOE Input Sources:}

- Association of American Railroads, AAR Railroad Cost Indices, (Washington, DC, quarterly)

- Historical railroad cost indices used to forecast rail network rate multipliers

- DRI/McGraw-Hill, Inc., EPS Model (Econometric Programming System, continuing subscription)

- Historical barge cost indices used to forecast barge network rate multipliers

- Rand-McNally \& Co., Handy Railroad Atlas of the United States, (Chicago, IL, 1988)

- Rail transportation nodes and links.

\section{DOE Data Input Sources:}

Forms and Publications:

- Energy Information Administration, Form EIA-3, 'Quarterly Coal Consumption Report--Manufacturing Plants"

- Annual tonnage consumption data used to subdivide Intermediate Future Forecasting System (IFFS) region demands for the residential/commercial, industrial, metallurgical and utility sectors into the 44 domestic CSTM regions

- Delivered coal prices to the nonutility sectors, used to derive base transportation rates

- Energy Information Administration, Form EIA-5, "Coke Plant Report - Quarterly"

- Data used to derive total metallurgical demand

- Annual tonnage consumption data used to subdivide Intermediate Future Forecasting System (IFFS) region demands for the residential/commercial, industrial, metallurgical and utility sectors into the $\mathbf{4 4}$ domestic CSTM regions

- Delivered coal prices to the nonutility sectors, used to derive base transportation rates

- Encrgy Information Administration, Form EIA-6, "Coal Distribution Report"

- Annual tonnage consumption data used to subdivide Intermediate Future Forecasting System (IFFS) region demands for the residential/commercial, industrial, metallurgical and utility sectors into the 44 domestic CSTM regions

- Energy Information Administration, Form EIA-7A, "Coal Production Report"

- Minemouth prices used to derive base transportation rates

- Federal Energy Regulatory Commission, FERC Form 423, "Monthly Report of Cost and Quality of Fuels for Electric Plants"

- Annual tonnage consumption data used to subdivide Intermediate Future Forecasting System (IFFS) region demands for the residential/commercial, industrial, metallurgical and utility sectors into the 44 domestic CSTM regions

- Federal Energy Regulatory Cominission, FERC Form 580, "Interrogatory on Fuel and Energy Purchase Practices"

- Updated rail base rates Models and Other 
- Energy Information Administration, Intermediate Future Forecasting System (IFFS)

- Coal demand

- Energy Information Administration, International Coal Trade Model (ICTM)

- Export demand

- Ocean collier base rates (based on calculations of the SEATRAN subroutine of the ICTM)

- Energy Information Administration, Resource Allocation and Mine Costing (RAMC) Model

- Coal supply curves

- Energy Information Administration, Tow Boat/Barge Operation Cost Model

- Barge base rates

- Energy Information Administration, 'Method of Generating Coal Barge Transportation Rates for the Coal Supply and Transportation Model," Memorandum (September 28, 1984) from Jim Watkins.

- Barge base rates.

\section{General Output Descriptions:}

- Physical:

- Forecasts of annual coal supply tonnages (and trillion Btu) by economic sector, coal supply region and coal type, and demand region

- Forecasts of coal transportation routes and modes between supply and demand points

- Economic:

- Forecasts of annual minemouth, transportation and delivered coal prices by coal type.

Computing Environment:

- Hardware Used: IBM 3084QX

- Operating System: MVS/XA

- Language/Software Used: VS FORTRAN

- Memory Requirement: $1800 \mathrm{~Kb}$

- Storage Requirement: 900 tracks, 3350 disk
- Estimated Run Time: 90 CPU seconds for a single year

- Special Features: None.

Independent Reviews Conducted:

- None.

Status of Evaluation Efforts by Sponsor: An audit of the CSTM was completed in December 1988 by the Energy Information Administration's Office of Statistical Standards, Quality Assurance Division. This audit included a comparison report of the archive tape and the documentation, an independent expert review by Roberto S. Mariano of the University of Pennsylvania, and a quality audit and sensitivity analysis by the Washington Consulting Group. Several recommendations are being operationalized: a price expectations module has been incorporated in the CSTM, and the model is in transition to a new method of estimating transportation rates based on the Federal Energy Regulatory Commission's Form 580.

\section{Data Resources Inc. Model of the U.S. Economy (DRI)}

Description: The DRI Model of the U.S. Economy represents national economic production and income corresponding to the National Income and Product Accounts published by the Department of Commerce. These forecasts of national activity extend 25 years and serve as the basis for EIA macroeconomic forecasts. EIA alters the DRI forecasts so that the energy variables included in the macroeconomic model correspond to EIA energy price forecasts.

Last Model Update: December 1992.

Part of Another Model? No.

Model Interfaces: None.

Sponsor:

- Office: Office of Integrated Analysis and Forecasting

- Division: Energy Demand and Integrating Division

- Branch: International Economics and Integrated Forecasting Branch, EI-812

- Model Contact: Kay A. Smith

- Telephone: 202-586-1455

Documentation: Available Fall 1993

Archive Media and Installation Manual(s): Not archived. 
Purpose: EIA uses the DRI Model of the U.S. Economy to generate macroeconomic growth cases. These growth cases are then used by the macroeconomic model (PCMAC) and used by IFFS in order to calculate macroeconomic feedback of changing energy prices.

Energy System Described by Model: None.

\section{Coverage:}

- Gecgraphic: Quarterly forecasts for 25 years at a national level.

- Time Unit/Frequency: Quarterly

- Product(s): Personal consumption expenditures, producers durable equipment investment, non-residential construction, residential construction and non-defense Government expenditures, Federal defense expenditures, exports, imports, inventory change in final goods, and inventory change in materials and work-inprocess.

- Economic Sector(s): Domestic spending, domestic income, tax policy, international, financial, inflation, simulated supply potential, expectations.

\section{Modeling Features:}

- Model Structure: The DRI Model forecasts roughly 1200 concepts encompassing final demands, aggregate supply, prices, incomes, interest rates, industrial detail, and international trade. There are eight blocks to the model: domestic spending, domestic income, tax sector, prices, financial, international trade, expectations, and aggregate supply. The domestic spending, income and tax blocks correspond to the National Income and Product Accounts. The rest of the blocks interact with the blocks describing domestic activity.

- Modeling Technique: Econometric simulation modeling techniques.

\section{Non-DOE Input Sources:}

- U.S. Department of Commerce (Washington, DC)

- Consumption

- Investment

- Residential construction

- Exports

- Imports

- Inventory change

- Defense spending.
DOE Data Input Sources:

None.

General Output Descriptions: The variables needed by PCMAC for the macroeconomic growth cases.

Computing Environment:

- Hardware Used: IBM-compatible PC with math coprocessor

- Operating System: DOS Version 5.0

- Language/Software Used: Proprietary DRI model software

- Memory Requirement: $64 \cap \mathrm{Kb}$

- Storage Requirement: 5 iviegabytes (Mb)

- Estimated Run Time: 20 minutes on $\mathbf{4 8 6}$ chip for 25-year simulation

- Special Features: None.

Independent Reviews Conducted: None.

Status of Evaluation Efforts by Sponsor: None.

\section{Electricity Market Model (EMM)}

Description: EMM is used by EIA as an analytical system for projecting the future state of the electricity market. This model is a major component of the Intermediate Future Forecasting System (IFFS). This representation of the electricity market accounts for the economic factors of supply and demand, the economic competition of fuels, and Government policies and regulations that deviate from purely economic behavior.

Last Model Update: September 1991.

Part of Another Model? Intermediate Future Forecasting System (IFFS)

Model Interfaces: EMM is one of the primary components of IFFS from which it derives estimates of projected fuel prices, electricity demands, inflation rates, and interest rates. In addition, capital costs for new plants are estimated by the Oak Ridge National Laboratory's CONCEPT Model.

Sponsor:

- Office: Office of Integrated Analysis and Forecasting

- Division: Energy Supply and Conversion Division 
- Branch: Nuclear and Electricity Analysis Branch, EI821

- Model Contact: Jeff Jones

- Telephone: 202-586-2038

Documentation:

- Energy Information Administration, Model Documentation: Electricity Market Module, DOE/EIA-MOOI (Washington, DC, December 1984)

- Energy Information Administration, Model Documentation: Electricity Market Module, DOE/EIA-0474 (Washington, DC, April 1989)

- Energy Information Administration, Software Documentation of the Capacity Expansion Component of the Electricity Market Model, DOE/EI/19801-H2 (Washington, DC, February 1989)

- Energy Information Administration, Model Methodology and Data Description of the Electricity Markei Module, Volume I: Overview, DOE/EIA-M038 (Washington, DC, August 1989)

- Energy Information Administration, Model Methodology and Data Description of the Electricity Market Module, Volume 2: Planning Component, DOE/EIA-M039 (Washington, DC, August 1989).

\section{Archive Media and Installation Manual(s):}

- The use of EMM as a module of IFFS for the Oil and Gas Annual Fuels Outlook 1990, the Annual Outlook for U.S. Electric Power 1990, and Annual Outlook for U.S. Coal 1990 is archived on an archive tape, IFFS 90.

- The use of EMM as a module of IFFS for the Annual Energy Outlook 1991, the Annual Outlook for Nil and Gas 1991, the Annual Outlook for U.S. Electric Fower 1991, and the Annual U.S. Electric Power 1991, and the Annual Outlook for U.S. Coal 1991 is archived on tape, IFFS91.

Purpose: EMM's objective is to simulate electric utility behavior in order to produce a forecast of electricity prices, fuel consumption patterns and expansion plans consistent with electricity demand forecasts.

Energy System Described by Model: EMM is a process model representing the domestic electricity market. EMiM represents the conversion of fossil fuels, nuclear power, hydropower, and other renewable energy sources into electricity. EMM translates the fixed and variable costs of production into electricity prices by simulating electric utility regulatory practices for both privately and publicly owned utilities. In addition, EMM formulates capacity expansion ? nlans to provide adequate capacity throughout the forecast horizon.

Coverage:

- Geographic: 10 Federal regions

- Time Unit/Frequency: Annually through 2010

- Product(s): Electricity prices, generation and demands, fuel consumption for coal, natural gas, distillate oil, low sulfur residual oil, high sulfur residual oil, nuclear power fossil fuel equivalent, and hydropower/other fossil fuel equivalent

- Economic Sector(s): Private and public electric utili‘ies.

Modeling Features:

- Model Structur : EMM is a process model simulating the decisionmaking behavior of electric utilities in choosing the appropriate mix of capacity to construct for future years, in allocating current plants to satisfy generation requirements, and in determining electricity prices consistent with demand estimates.

- Modeling Technique: EMM is modular in its relation to the Intermediate Future Forecasting System and in the relationship among the components which define the model. In addition, EMM is largely data-driven in that the core software (those routines which implement the methodology) do not depend on region and forecast year.

- Special Features: The primary design feature of the EMM is its modularity. The model is composed of four loosely linked components: planning, dispatch, pricing, and demand. Any of these components may be replaced by a new representation with only minimal direct interface required. The modularity allows EMM and the National Utility Financial Statement Model to use the same software. The common subroutines are datid driven and serve both functions equally well and allow for maintenance and development of only one set of software.

\section{Non-DOE Input Sources:}

- Oak Ridge National Laboratory, Concept-5 User's Manual, 1979

- Initial unit cost of capacity

- Capital cost associated with each type of new unit

- Construction profile

- Construction lead time 
- J.A. Reyes Associates, Regionalized Capital and Operating and Maintenance (O\&M) Cost Estimates for Emission Control Equipment Required for New Fossil Steam Power Plants, January 1984

- Operations and maintenance costs (coal)

- Heat rate (coal)

- Initial unit cost of capacity (coal)

- Data Resources Inc., U.S. Long-tenn Review, Fall 1984

- Historical GNP deflators

- Electric Power Research Institute, Technical Assessment Guide, Volume 1: Electricity Supply--1986

- Operations and maintenance costs (oil and gas)

- Down time

- Heat rate (oil and gas)

- Initial unit cost of capacity (oil and gas)

- Capital cost associated with each type of new unit

- Reliability

- ICF, Inc., "Forecasts of Electric Utility Transmission and Distribution Capital Expenditures," Memorandum (January 21, 1987) to Robert Eynon, EIA, from Mark Inglis and Judah Rose.

- Transmission and distribution capital expenditures

- J.A. Reyes Associates, Regionalized Capital, Operating and Maintenance Cost Estimates for Emission Control Equipment Required for New Fossil Steam Power Plants, January 1984

- Operations and maintenance costs (coal)

- Heat rate (coal)

- Initial unit cost of capacity (coal).

DOE Data Input Sources:

Forms and Publications:

- Energy Information Administration, Form EIA-254, "Semi-annual Report on Status of Reactor Construction"

- Book value of canceled nuclear plants
- Length of the construction period for each new unit

- Energy Information Administration, Form EIA-759, "Monthly Power Plant Report"

- Maximum fuel shares for existing capacity

- Federal Energy Regulatory Commission, FERC Form 423, "Monthly Report of Cost and Quality of Fuels for Electric Plants"

- Fuel shares

- International Affairs and Energy Emergencies, Form IE-411, "Coordinated Regional Bulk Power Supply Prograin Report"

- Base load adjustment for interregional transfers

- Fuel cost adjustment for purchased power

- Adjustment to revenues for bulk power sales

- Federal Energy Regulatory Commission, FERC Form 1, "Annual Report of Major Electric Utilities, Licensees and Others"

- Unit capital cost of capacity

- Tax rates

- Accumulated book depreciation

- Accumulated deferred taxes

- Total utility plant in service

- Total capitalization

- Invesument tax credit rate

- Construction work in progress

- Embedded cost of capital

- Energy Information Administration, Form EIA-412, "Annual Report of Publicly Owned Electric Utilities"

- Tax rates

- Accumulated book depreciation

- Accumulated deferred taxes

- Total utility plant in service

- Total capitalization

- Invesunent tax credit rate 
- Construction work in progress

- Embedded cost of capital

- Energy Information Administration, Form EIA-860, "Annual Electric Generator Report"

- Capacity levels

- Energy Information Administration, Trends in Electric Utility Load Duration Curves, DOE/EI-19635-1, (Washington, DC, December 1984)

- Coefficients of unitized load duration curves

- Shares of annual demand for electricity

Models and Other:

- Energy Information Administration, Office of Integrated Analysis and Forecasting

- Canadian and Mexican imports

- Energy Information Administration, Office of Coal, Nuclear, Electric and Alternate Fuels

- Transmission/distribution loss fractions

- Energy Information Administration, Office of Coal, Nuclear, Electric and Alternate Duels

- Fuel price growth rates--coal

- Energy Information Administration, Office of Energy Markets and End Use

- Fuel price growth rates--oil

- Energy Information Administration, Office of Oil and Gas, Reserves and Natural Gas Division

- Fuel price growth rates--gas.

General Output Descriptions: EMM provides information on electricity demand, supply, and financial information for the 10 Federal regions as well as for the entire United States. The data are used for analysis by the Department of Energy and other analysts and are published in the Annual Energy Outlook 1993 and the Supplement to the Annual Energy Outlook 1993.

Computing Environment:

- Hardware Used: IBM 3084QX

- Operating System: MVS/XA

- Language/Software Used: FORTRAN 77
- Memory Requirement: $2048 \mathrm{~Kb}$

- Storage Requirement: $2048 \mathrm{~Kb}$

- Estimated Run Time: 5 CPU minutes for years 19852010

- Special Features: EMM may be run as part of IFFS or as a stand-alone module. In addition, SAS is used in data processing.

Independent Reviews Conducted: Ed Hillsman of Oak Ridge National Laboratory (ORiNL) conducted a review of EMM in 1984-85. Timothy Mount of Cornell University and James Plivismer of QED Research conducted reviews of EMM in 1990.

Status of Evaluation Efforts by Sponsor: EMM is currently being evaluated by the Oak Ridge National Laboratory.

\section{Gas Analysis Modeling System (GAMS)}

Description: GAMS covers all aspects of the natural gas market from producers, through pipeline companies and distributors, to the consumer. GAMS encompasses the production of natural gas, imports of gas, natural gas contract pricing and take-or-pay provisions for production purchases; pricing by pipeline companies and distributors; projected demand for each sector; and transmission and distribution of natural gas. Forecasts are generated through the year 2010. The model is used to forecast a supply and demand balance of gas markets and to analyze the natural gas industry.

Last Model Update: December 1990.

Part of Another Model? No, but may be run with Intermediate Future Forecasting System (IFFS) and Demand Evaluation Modeling System Integrating Module (DEMS).

Model Interfaces: IFFS and PROLOG.

Sponsor:

- Office: Office of Integrated Analysis and Forecasting

- Division: Energy Supply and Conversion Division

- Branch: Oil and Gas Analysis Branch, EI-823

- Model Contact: Phyllis Martin

- Telephone: 202-586-9592

Documentation: Energy Information Administration, Modcl Documentation of the Gas Analysis Modeling System, DOEFEA-1MO44'S1) (Wastington, DC, May 1001).

Archive Media and Installation Manual(s): 
- GAMS82(AO) - Archived for the Annual Energy Outlook 1982.

- GAMS82(P4) - Archived for the Part IV Study.

- GAMS83 - Archived for the Annual Energy Outlook 1983.

- GAMS84 - Archived for the Annual Energy Outlook 1984.

- GAMS85 - Archived for the Annual Energy Outlook 1985.

- GAMS86 - Archived for the Annual Energy Outlook 1986.

- GAMS88 - Archived for the Annual Outlook for Oil and Gas 1988, the Annual Outlook for U.S. Electric Power 1988, and the Annual Outlook forU.S. Coal 1988.

- GAMS89 - Archived for the Annual Outlook for Oil and Gas 1989, the Annual Outlook for U.S. Electric Power 1989, the Annual Outlook forU.S. Coal 1989, and Electricity Generation from Natural Gas: Prospects and Implications for the United States.

- GAMS90 - Archived for the Annual Outlook for Oil and Gas 1990, the Annual Outlook for U.S. Electric Power 1990, and the Annual Outlook forU.S. Coal 1990.

- GAMS91 - Archived for the Annual Energy Outlook 1991 and for the Annual Outlook for Oil and Gas 1991.

- GAMS91EX - Additional Computer Runs of the Gas Analysis Modeling System, archived for the Intemational Energy Outlook 1991 and the Annual Outlook for Oil and Gas 1991.

Purpose: GAMS is used by the Oil and Gas Analysis Branch in the Office of Integrated Analysis and Forecasting as an analytic aid to support preparation of regional projections of reserves, production and consumption of natural gas, and the potential effects of alternative policies, regulations, and economic environments on domestic gas market balances. The annual projections and associated analyses appear in the Annual Energy Outlook (DOE/EIA0383) of the Energy Information Administration, and other special analyses.

Energy System Described by Model: GAMS is a modular, multiregional, time-stepped (annual), partial equilibrium model of domestic natural gas markets. Production from existing gas reserves are categorized as defined by the Natural Gas Policy Act (NGPA). Production from reserves are solved at the level of groups of major pipelines. Annual demand is solved at the regional level for end-use sectors. Key determinants of market balance are prices of gas and alternate fuels, exploratory/developmental drilling activity, macro-economic growth, regulations and market conditions.

Coverage:

- Geographic: Production regions are defined in PROLOG, plus the offshore region and Alaska. Demand regions are the 10 Federal regions

- Time Unit/Frequency: Annually through 2010

- Product(s): Natural gas

- Economic Sector(s): Residential, commercial, industrial, transportation, and electric utility.

Modeling Features:

- Model Structure: Modular; containing four major components

- Supply: provides estimates of natural gas supply

- Demand: provides detailed sectoral end-use demand requirements

- Transactions Network: represents the transmission and distribution of natural gas

- Market Equilibration: solves the entire system for natural gas wellhead prices at which supply and demand balance.

- Modeling Technique: GAMS simulates the U.S. production/delivery/ demand system for natural gas. GAMS contains a modular system of equations linking gas discovery, production, production rates, and consumption to geological, engineering, economic, and institutional determinants.

- Special Features: GAMS can run stand-alone or in conjunction with IFFS/DEMS. GAMS incorporates the primary economic, geological, engineering, and institutional factors that are assumed to determine feasible levels of annual gas production and domestic market balances. Unique among annual gas market models, it incorporates:

- Calibration of historical market distribution data in the simulation, enabling refinement and benchmarking of projections with updated data

- State/sector detail by articulated tracing of transmission/distribution to State market sectors to accumulate user demands

- Explicit representation of characteristic provisions of wellhead contracts. 
- The variables included in the GAMS' information base that may be affected by future policy, regulatory, or economic conditions and that in turn affect annual domestic gas market balances are:

- Domestic gas wellhead prices and contract terms

- World crude oil prices

- Import deliverability

- Availability of Alaskan gas

- Domestic tax, interest, and inflation rates

- The effects of various alternative gas policies and regulations can be analyzed in terms of their effects on marlet balances.

\section{Non-DOE Input Sources:}

- Dwight's Energydata Tape Files

- Gas reserves supply data

- American Petroleum Institute Well Completion Data

- Gas reserves supply data

- Bureau of the Census

- 1984 estimated population projections for 1984 through 1995

- Industry Data

- Data used to estimate transmission loss per mile, wellhead to pipegate loss and multiplication factor for conversion from monthly to daily load factors

- 1980 data used to estimate base year charges (demand and commodity charges) and transmission distance

- National Bureau of Standards

- Data used to estimate transmission loss per mile, wellhead to pipegate loss and multiplication factor for conversion from monthly to daily load factors

- 1980 data used to estimate base year charges (demand and commodity charges) and transmission distance

- Gas Research Institute, Baseline Projection Data Book, 1989

- Average historical (1988) utility tariffs
- 1981 Purchased Gas Adjustment Filings

- Gas contract information (pipeline system, market, NGPA section, type of contract and type of well)

- Average price of contracts with definite only clauses

- Proportions of gas with each type of contract clause

- Weighted average contract (wellhead) price of controlled natural gas

- Price adjustment factors

- American Gas Association, Gas Industry Action by Field Purchasers to Reduce Gas Cost, February 1984

- $\quad$ Market out prices for 1984 and 1985

- Percent of reserves to receive market out price

- Adjusted weighted average contract (wellhead) price of natural gas.

DOE Data Input Sources:

Forms and Publications:

- Energy Information Administration, Form EIA-23, "Annual Survey of Domestic Oil and Gas Reserves"

- Annual estimate of gas reserves by type and State

- Energy Information Administration, Form EIA-176, "Annual Report of Natural and Supplemental Gas Supply and Disposition"

- Annual natural gas sources of supply and consumption average day flow for node)

- Energy Information Administration, Form EIA-758, "Natural Gas Producer/Pipeline Contract Report"

- Distribution of contract clauses for existing contracts

- Energy Information Administration, Form EIA-857, "DOE Monthly Report of Natural Gas Purchases and Deliveries to Consumers"

- City-gate prices

- Federal Energy Regulatory Commission, FERC Form 2, "Annual Report for Major Natural Gas Companies"

- Annual purchases/sales by pipeline (volume and price) 
- Federal Energy Regulatory Commission, FERC Form 15, 'Interstate Pipeline's Annual Report of Gas Supply"

- Annual status of reserves

- Commitments to pipeline companies

- Annual gas production, storage, interstate movements, and consumption

- Federal Energy Regulatory Commission, FERC Form. 50, "Alternative Fuel Demand Due to Natural Gas Deficiencies Report"

- 1980 data used to estimate base year charges (demand and commodity charges) and transmission distance

- Number of network rodes

- Number of network arcs

- Network node data (State; type; ID's of first, last and primary arcs; number of arcs; storage capacity; and fraction of gas lost)

- Network arc data (origin and destination nodes, ID of next arc, current year gas quantity and price, 1980 tariff rate specification and fraction of gas used)

- Network data by pipeline system

- Federal Energy Regulatory Commission, FERC Form 121, "Application for Determination of the Maximum Lawful Price Under the Natural Gas Policy Act of 1978"

- Gas reserves supply data

- Federal Energy Regulatory Commission, FERC Form 123, "Initial Report of First Sale of Natural Gas Under Section 105, Natural Gas Policy Act, Existing Interstate Contract."

- Contract data

Models and Other:

- Energy Information Administration, Oil Market Simulation Model (OMS-PC)

- World oil price

- Energy Information Administration, Intermediate Future Forecasting System (IFFS)

- End-use demands for utility sector and prices for other fuels
- Energy Information Administration, Demand Evaluation Modeling System Integrating Module (DEMS)

- End-use demands for residential, commercial, industrial, and transportation sectors

- Energy Information Administration, Petroleum Marketing Division

- Motor fuels tax by region.

General Output Descriptions:

" GAMS reports three broad aspects of the natural gas market on a historical and forecast basis:

- annual status of reserves and production by NGPA category

- annual pipeline system wellhead volumes and prices

- annual consumption and prices by sector and region

The annual reports include the following:

- total gas production and consumption

- net imports and prices

- average price and consumption by region, by region/end-use sector, and by end-use sector ("region" denotes Census region and DOE region).

\section{Computing Environment:}

- Hardware Used: IBM $3090-400 E$, IBM $3084 Q X$ or $360 / 370$ (or equivalent)

- Operating System: MVS/XA or OS or OS/VS

- Language/Software Used: FORTRAN (VS compiler, Version 2, Level 2.4.0) and XMP (a specially designed proprietary linear programming package, callable from FORTRAN, developed by Roy E. Marsten)

- Memory Requirement: $6000 \mathrm{~Kb}$

- Storage Requirement: 3350 permanent disk -- 700 tracks for the source and load modules

- Estimated Run Time: On an IBM 3090-400E operating under MVS/XA, 4 minutes

- Special Features: GAMS uses a proprietary software package XMP. This is a specially designed linear programming package that is callable from FORTRAN. 
Independent Reviews Conducted: Assessment of Natural Gas Market Models, Charles River Associates, (Boston, Massachusetts, April 1984).

Status of Evaluation Efforts by Sponsor: Model Quality Audit: Gas Analysis Modeling System (GAMS) completed December 1991.

\section{Industrial Model (IM)}

Description: IM is used to forecast annual industrial sector energy consumption through the year 2010. Most of the equations are econometrically based and are logically organized into sectors consisting of manufacturing heat and power, nonmanufacturing heat and power, and feedstocks (raw materials), and "other" fuels.

Last Model Update: September 1992.

Part of Another Model? Part of IFFS.

Model Interfaces: Exogenous input forecasts (prices, etc.) are received from IFFS, and consumption outputs are sent to IFFS.

\section{Sponsor:}

- Office: Office of Integrated Analysis and Forecasting

- Division: Energy Demand and Integration Division

- Branch: Energy Demand Analysis Branch, EI-813

- Model Contact: Amelia Elson

- Telephone: 202-586-1504

Documentation: Energy Information Administration, $P C$ $A E O$ Forecasting Model for the Annual Energy Outlook 1990: Model Documentation (Section 5, Industrial Energy Demand), DOE/EIA-M036(90) (Washington, DC, March 1990) and Technical Notes.

Archive Media and Installation Manual(s): Archived as part of IFFS.

Purpose: The purpose of the industrial model is to forecast industrial sector energy demand by fuel types and industries in the long term.

Energy System Described by Model: Forecasts of consumption for heat and power are generated for purchased electricity, self-generated electricity, natural gas, residual oil, distillate oil, steam coal, metallurgical coal, liquid petroleum gas, lubricants, motor gasoline, petroleum coke, still gas, special naphthas, asphalt, and hydropower. Forecasts of consumption for raw materials are generated for liquid petroleum gas, natural gas, and petrochemical feedstocks.

\section{Coverage:}

- Geographic: Four Census regions

- Time Unit/Frequency: Annual to the year 2010

- Product(s): Fuels and electricity consumed for heat and power and for raw materials

- Economic Sector(s): Eight manufacturing sectors, agriculture, construction, mining, raw materials and miscellaneous.

\section{Modeling Features:}

- Model Structure: Eight manufacturing sectors, agriculture, construction, mining, raw materials and miscellaneous.

- Modeling Technique: Ordinary least squares with log transformations and corrections for autocorrelation.

- Special Features: None.

\section{Non-DOE Input Sources:}

- Data Resources, Inc. (DRI) U.S. Central (USCEN) data base

- Macroeconomic inputs (real U.S. GNP; prices of capital, labor and materials; industrial output; refinery production; coal production; oil/gas production; world oil price; dry gas production; and lease and plant natural gas consumption)

- Historical macroeconomic variables (GNP price deflator; rental price of capital and net capital stock; and index for unit labor cost, nonfarm)

- Bureau of Labor Statistics

- Industrial output

- Department of Commerce, National Energy Accounts

- Manufacturing sector: consumption and expenditures

- Bureau of the Census, Annual Suney of Manufactures (ASM)

- Manufacturing sector: consumption and expenditures

- Jack Faucett \& Associates 
- Manufacturing sector: consumption and expenditures.

\section{DOE Data Input Sources:}

Forms and Publications:

- Energy Information Administration, Short-Tern Energy Outlook, DOE/EIA-0202 (Published Quarterly)

- Benchmark/calibration levels (1986-1990)

- Energy Information Administration, Monthly Energy Review, DOE/EIA-0035

- Benchmark/calibration levels (1985-1988)

- Energy Information Administration, Forms EIA846A/D, "Manufacturing Energy Consumption Survey"

- Manufacturing sector: consumption and expenditures

Models and Other:

- Energy Information Administration, IFFS

- Macroeconomic inputs (real U.S. GNP; prices of capital, labor and material; industrial output; refinery production; coal production; oil/gas production; world oil price; dry gas production; and lease and plant natural gas consumption)

- Fuel prices

- Benchmark/calibration parameters (benchmark switch, benchmark/calibration levels (1986-1990 and benchmark factors)

- Energy Information Administration, Coal Price and Supply Model (COAL-PC)

- Coal production

- State Energy Data System (SEDS)

- Benchmark/calibration levels (1986-1990)

- Feedstocks (raw materials)

- State Energy Price and Expenditures Data System (SEPEDS)

- Manufacturing sector: consumption and expenditures

- Office of Coal, Nuclear, Electric and Alternate Fuels

- Self-generated electricity
- Fuels used for self-generated electricity

General Output Descriptions: Annual consumption of fuels and electricity to 2010 .

Computing Environment:

- Hardware Used: IBM 3084QX (or equivalent)

- Operating System: MVS/XA

- Language/Software Used: VS FORTRAN

- Memory Requirement: $500 \mathrm{~Kb}$

- Storage Requirement: 300 tracks of an IBM 3380 disk pack

- Estimated Run Time: 5 minutes in an irtegrated mode on an IBM $3084 Q \mathrm{X}$

- Special Features: None.

Independent Reviews Conducted: Outside review of previous version by G.S. Maddala in June 1988, and ongoing.

Status of Evaluation Efforts by Sponsor: None.

\section{Intermediate Future Forecasting System (IFFS)}

Description: IFFS represents U .S. energy supply, distribution, and consumption by fuel supply and consumption sector, given an assumption of the world crude oil price and a macroeconomic projection of economic growth. A detailed representation of utility and nonutility electricity generation and capacity expansion (EMM) provides the demand for oil, coal, natural gas, renewable, and nuclear generation, and the prices of electricity. An econometric representation of refinery pricing (OMM) provides oil product prices. A coal supply and transportation model (CSTM) provides the delivered price of coal. The Gas Analysis Modeling System/Production of Onshore Lower 48 Oil and Gas Model (GAMS/PROLOG) computes the production of domestic oil and gas and the wellhead and end-use prices of natural gas. IFFS solves for the market equilibrium for each fuel by balancing supply and demand to produce an energy balance in each forecast year. The model currently forecasts to the year 2010 .

Last Model Update: September 1992.

Part of Another Model? No.

Model Interfaces:

- Gas Analysis Modeling System (GAMS)

- Production of Onshore Lower 48 Oil and Gas (PROLOG) Model 
- Oil Market Module (OMM)

- Electricity Market Model (EMM)

- International Coal Trade Model

- (ICTM) Coal Supply and Transportation Model (CSTM)

- National Coal Model (NCM)

- Resource Allocation and Mine Costing (RAMC) Model

- National Utility Financial Statement (NUFS) Model

- Building Energy End-Use Model (BEEM)

- Residential Energy End-Use Demand Model (REEM).

\section{Sponsor:}

- Office: Office of Integrated Analysis and Forecasting

- Division: Energy Demand and Integration Division

- Branch: National Energy Modeling System Branch, EI-811

- Model Contact: Paul Kondis

- Telephone: 202-586-1469

Documentation:

- Decision Analysis Corporation, Model Documentation Report: The Oil Market Model (McLean, VA, September 1990)

- Energy Information Administration, Coal Supply and Transportation Model: Model Description, DOE/EIAMO22 (Washington, DC, June 1987)

- Energy Information Administration, Demand Models and Macroeconomic Model as Used for the Annual Energy Outlook 1991 (Washington, DC)

- Energy Information Administration, Documentation of the Integrating Module of the Intermediate Future Forecasting System, DOE/EIA-M023 (Washington, DC, May 1991)

- Energy Information Administration, Intermediate Future Forecasting System Executive Summary, DOE/EIA-0430 (Washington, DC, October 1983)

- Energy Information Administration, Model Documentation: Electricity Market Module, DOE/EIA-MOO1 (Washington, DC, December 1984)
- Energy Information Administration, Model Documentation of the Gas A nalysis Modeling System, DOE/EIA0450(91) (Washington, DC, March 1991)

- Energy Information Administration, Model Methodology and Data Description of the ElectricityMarket Module, Volume I: Overview, DOE/EIA-MO38 (Washington, DC, August 1989)

- Energy Information Administration, Model Methodology and Data Description of the Electricity Market Module, Volume II: Planning Component, DOE/EIA-MO39 (Washington, DC, August 1989)

- Energy Information Administration, Model Methodology and Data Description of the Production of Onshore Lower 48 Oil and Gas Model, DOE/EIA-MO34(91) (Washington, DC, April 1991).

Archive Media and Installation Manual(s):

- IFFS83 - for the Annual Energy Outlook 1983

- IFFS84 - for the Annual Energy Outlook 1984

- IFFS85 - for the Annual Energy Outlook 1985

- IFFS86 - for the Annual Energy Outlook 1986

- IFFS88 - for the Annual Outlook for U.S. Electric Power 1988 and the Annual Outlook for U.S. Coal 1988

- IFFS89 - for the Annual Outlook for Oil and Gas 1989, Annual Outlook for U.S. Electric Power 1989, the Annual Outlook for U.S. Coal 1989, and Electricity Generation from Natural Gas: Prospects and Implications for the United States

- IFFS90 - for the Annual Outlook for Oil and Gas 1990 , Annual Outlook for U.S. Electric Power 1990, and the Annual Outlook for U.S. Coal 1990

- IFFS91 - for the Annual Energy Outlook 1991, Annual Outlook for Oil and Gas 1991, Annual Outlook for U.S. Electric Power 1991, and the Annual Outlook for U.S. Coal 1991

- IFFS92 - for the Annual Energy Outlook 1992

- $\quad$ IFFS93 - for the Annual Energy Outlook 1993.

Purpose: The objective of the IFFS is to account for the many interactions of the different segments of the energy industries and to provide an internally consistent forecast of prices and quantities for which supply equals demand. This equilibrium solution accounts for the main economic factors affecting supply and demand, allows price competition of fuels, and accounts for policies and regulations that cause deviations from purely economic behavior. 
Energy System Described by Model: IFFS is a partial equilibrium model of domestic energy supply and demand. IFFS represents the domestic production of oil, natural gas, coal, and the imports/exports of crude oil, natural gas, and refined petroleum products, coal and electricity. It also represents the two major energy conversion activities, the refining of crude oil into petroleum products and the conversion of fossil fuels, nuclear power, hydropower and other renewable sources into electricity. Consumption of energy is represented by four end-use sectors: residential, commercial, industrial, and transportation.

\section{Coverage:}

- Geographic: United States. Different modules represent energy production or consumption at different levels of regional detail. The price and quantity interface between modules is at the $10 \mathrm{Federal}$ region levels.

- Time Unit/Frequency: Annual through 2010

- Product(s): Natural gas, electricity, coal, steam coal, metallurgical coal, distillate fuel oil, residual fuel oil, motor gasoline, jet fuel, liquefied petroleum gases, $n$,irochemical feedstocks, kerosene, other petroleum wuducts, and hydropower and other renewable sources.

- Economic Sector(s): Residential, commercial, industrial and transportation end-use consumption; coal supply; oil and gas production and natural gas markets; utility and nonutility capacity, and generation of electricity; oil product pricing.

\section{Modeling Features:}

- Model Structure: IFFS provides an equilibrium framework in which the economic forces of supply and demand can be simulated. Due to its modularity, IFFS allows each individual module to be represented in a different fashion if desired.

- Modeling Technique: The oil module is a series of econometric equations for oil product pricing. The coal module incorporates existing contracts, simulates the pricing of coal supplies from all existing mines and new mines, and combines the mine costing with cost of transportation to solve a least-cost-of-supply network algorithm. The electricity module simulates the decisionmaking behavior of utilities and nonutilities in choosing the projected least-cost capacity to construct for future years and the allocation of current plants for generation. The oil and gas supply model is an engineering-economic representation of oil and gas exploration and production and gas distribution and pricing. The macroeconomic and demand models are combinations of econometric and structural techniques. The model is basically designed as a simulation model, as such it is predictive, not normative.
- Special Features: The primary design feature of IFFS is its modularity. That is, the model is organized by fuel production--oil, natural gas, coal, and electricity--and by end-use consumption sector. Any of these sectors can be replaced by a simple representation when detailed results are not required. The modularity also allows any single sector or group of sectors to be run independently as a debugging aid or for stand-alone analysis. Furthermore, the modularity also allows the flexibility for each sector to be represented in the way most appropriate, highlighting the particular issues important for the sector, including the regional structure most appropriate.

Non-DOE Input Sources: All data sources are listed under appropriate modules of IFFS.

\section{DOE Data Input Sources:}

All data sources are listed under appropriate modules of IFFS. All model sources are listed under the Model Interfaces section.

General Output Descriptions: The following data elements are generally used in published reports; however, more detailed information is likely to be available:

- Total energy supply and disposition

- Domestic production by fuel type

- Imports and exports by fuel type

- Electric utility and nonutility fuel consumption, generation, and capacity

- Electricity disposition and end-use sectoral, regional prices

- Petroleum supply, disposition and end-use sectoral, regional prices

- Natural gas supply, disposition and end-use sectoral, regional prices

- Coal supply, disposition and end-use sectoral, regional prices

- Consumption of energy by fuel, sector, and region.

Computing Environment:

- Hardware Used: IBM 3090

- Operating System: MVS/XA

- Language/Software Used: FORTRAN 77

- Memory Requirement: $7000 \mathrm{~Kb}$, when all modules are being executed 
- Storage Requirement: $2500 \mathrm{~Kb}$

- Estimated Run Time: $40 \mathrm{CPU}$ minutes when all modules are being executed

- Special Features: None.

Independent Reviews Conducted:

- Hausman, Jerry A., independent expert reviewer, Interim (sic) Future Forecasting System Model Documentation, February 1982.

- National Bureau of Standards, U.S. Department of Commerce, Intermediate Future Forecasting System, Proceedings of a Symposium held at the Department of Energy, Washington, DC, August 19, 1982, NBS-670 (Washingtor, DC, December 1983).

Status of Evaluation Efiorts by Sponsor: None.

\section{International Coal Trade Model (ICTM)}

Description: ICTM projects coal trade flows from 20 coalexporting regions of the world to 9 demand regions for 3 types of coal: metallurgical, low-sulfur steam, and high-sulfur steam. The model consists of supply, demand, trade and transportation constraint components, the latter representing alternate routes of passage (Panama Canal, Suez Canal, direct ocean-going) and ship size (30,000 to 250,000 deadweight tons). The major coal producing countries (United States, Australia, South Africa, Canada, and Poland) are represented, as well as countries that could become major coal exporters (Colornbia, Venezuela, and China).

Last Model Update: December 1987.

Part of Another Model? Provides input to the National Coal Model (NCM), the Coal Supply and Transportation Model (CSTM), and the Intermediate Future Forecasting System (IFFS).

\section{Model Interfaces:}

- Resource Allocation and Mine Costing (RAMC) Model

- National Coal Model (NCM)

- Coal Supply and Transportation Model (CSTM)

- Intermediate Future Forecasting System (IFFS).

\section{Sponsor:}

- Ofilce: Office of Integrated Analysis and Forecasting

- Division: Energy Supply and Conversion Division
- Branch: Coal, Uranium and Renewable Fuels Analysis Branch, EI-822

- Model Contact: Robert Manicke

- Telephone: 202-586-2157

Documentation:

- Intemational Coal Trade Model, Version 2 (ICTM-2) Users Guide, DOE/EIA-M026, March 1987

- Intemational Coal Trade Model: Executive Summary, DOE/EIA-0444, May 1984

- Description of the Intemational Coal Trade Model, DOE/EI/11815-1, September 1982

- Mathematical Structure of the Intemational Coal Trade Model, DOE/NBB-0025, September 1982.

Archive Media and Installation Manual(s):

- ICTM81 - Annual Report to Congress 1981

- ICTM82 - Annual Energy Outlook 1982

- ICTM82A - Railroad Deregulation: Impact on Coal

- ICTM82B - Port Deepening and User Fees: Impact on U.S. Coal Exponts

- ICTM83 - Annual Energy Outlook 1983

- ICTM84 - Annual Energy Outlook 1984

- ICTM85 - Annual Energy Outlook 1985

- ICTM86 - Annual Energy Outlook 1986

- $\quad$ ICTM87 - Annual Energy Outlook 1987

- ICTM90-Annual Energy Outlook 1991 and the Annual Prospects for World Coal Trade 1991

- ICTM91 - Annual Energy Outlook 1992 and the Annual Prospects for World Coal Trade 1992.

Purpose: The ICTM is a static equilibrium model used by EIA to represent the international coal market. The model is used to assess the consequences of events and issues relating to world coal trade and U.S. coal exports, and to forecast coal trade based on the various assumptions concerning world coal supply and demand. U.S. coal export projections developed by using the ICTM appear in EIA's Annual Energy Outlook. These and other forecasts are provided as a service to other components of the Department of Energy, the Federal Government, and non-Federal public and private institutions concerned with U.S. coal exports. 
Energy System Described by Model: ICTM balances supply and demand in the international coal trade market. The ICTM is designed to compute the trade between coal exporters and coal importers, given supply and demand curves for each participant and other data that reflect final prices, such as transportation costs, constraints on routes, port capacities, coal preparation costs, and taxes.

\section{Coverage:}

- Geographic: The ICTM consists of 20 coal-exporting regions, corresponding to countries or subregions, and 9 coal demand regions. A region may represent either an individual country or a group of countries.

- Time Unit/Frequency: For any forecast year, but generally run for $1995,2000,2005$, and 2010

- Product(s): Metallurgical coal, low-sulfur steam coal, high-sulfur steam coal

- Economic Sector(s): Electric utilities, steel-making and other industries.

\section{Modeling Features:}

- Model Structure: The ICTM consists of three major analytical components:

- Supply Component. The ICTM models coal production activities based upon supply curves generated by formal mine-costing techniques or resource depletion formulas to represent minemouth costs. Inland transportation costs between the mines and ports are added to the minemouth costs of coal.

- Demand Component. Export coal demand is divided between coal price-elastic demand markets, and coal price-inelastic demand markets. For the price elastic demand markets, coal demand is calculated as a function of observed prices and quantities and of the price elasticity of coal demand. Price-elastic demand markets encompass Organization for Economic Cooperation and Development (OECD) countries. Price-inelastic markets are classified as such primarily because of insufficient information on these markets, their relatively minor participation in world coal trade, or their unresponsiveness to price.

- Transportation Component. Ocean transportation costs are required for the computation of delivered costs and are computed for each supplydemand link. The ocean transportation costs used in the ICTM are generated by computing auxiliary model SEATRAN, which calculates the various long-run costs of shipping coal (i.e., capital costs, operating costs, fuel costs and loading and unload- ing costs) for each projection year by selecting the least-cost option from various possible vessel sizes and routes.

- Modeling Technique: Coal supply step functions and demand curves, which represent long-run producer and consumer behavior in response to price, are modeled in the ICTM. Equilibrium is reached, in economic terms, when the total of producer and consumer surplus is maximized, (using a linear programming algorithm). In each projection year, the amount of coal supplied will exactly equal the amount demanded.

- Special Features: The ICTM is a system of computer models, submodels, data bases, and model interfaces that constitute an integrated framework of analysis. The variables included in ICTM's data base are: minemouth costs, inland transportation costs, ocean transportation costs, constraints on production, trade, transportation, port capacities, and taxes or subsidies.

\section{Non-DOE Input Sources:}

- Published trade and business journal articles, including Coal Age, Intemational Coai Keport, World Coal, Coal Outlook, and other trade journals.

- Coal supply curves--other suppliers

- Data used to estimate domestic demand--other countries

- Data used to estimate upper bounds on shipments of coal

- Data used to estimate upper bound on total coal produced (for export)--other countries

- Data used to estimate port dues

- Lower bounds on shipments

- Data used to estimate taxes and subsidies

- U.S. Maritime Administration, Existing and Potential U.S. Coal Loading Tenninals

- Data used to estimate port dues

- Australian Coal Repon

- Data used to estimate port dues

- U.S. Code of Federal Regulations (35)

- Upper limit on shipments through Panama Canal

- Panama Canal Commission, Panama Canal Annual Report, Washington, DC 
- Upper limit on shipments through Panama Canal

- Organization for Economic Cooperation and Development, Maritime Shipping, Paris

- Upper limit on shipments through Kiel Canal

- Suez Canal Annual Repont

- Upper limit on shipments through Suez Canal

- Supplyand Demand for United States Coking Coals and Metallurgical Coke, E.T. Sheridan, U.S. Department of the Interior, Bureau of Mines, 1976

- Mixing fraction for metallurgical coal

- Australian Department of Trade and Resources

- Coal supply curves--Australia

- Domestic demand--Australia

- Upper bound on total coal produced (for export) -- Australia

- Energy, Mines, and Resources--Canada

- Coal supply curves--Canada

- Domestic demand--Canada

- Upper bourid on total coal produced (for export) .- Canada

- The World Bank/Trade and Business Journals

- Coal supply curves--other suppliers

- Data used to estimate domestic demand--other countries

- Minerals Bureau, South Africa

- Coal supply curves--South Africa

- Upper bound on total coal produced (for export) -- South Africa

- ICF, Inc., Coal Supply Curves for A ustralia, Canada and South Africa, Fall 1980.

- Coal supply curves--Australia, Canada and South Africa

- Inland transportation costs--Australia, Canada and South Africa

- New South Wales Joint Coal Board
- Coal supply curves--Australia

- Domestic demand--Australia

- Upper bound on total coal produced (for export) -- Australia.

DOE Data Input Sources:

Forms and Publications: None.

Models and Other:

- Energy Information Administration, Resource Allocation and Mine Costing Model (RAMC)

- Coal supply curves--United States

- Energy Information Administration, OECD Country Energy Demand Model

- Reference demand curves--OECD countries

- Energy Information Administration Estimates

- Reference demand curves--other countries

- Domestic demand--other countries

- Upper bounds on shipments of coal

- Upper bound on total coal produced (for export) -- other countries

- Loading and unloading costs

- Taxes and subsidies

- Mixing charge

- Energy Information Administration, National Coal Model (NCM)

- Domestic demand--United States

- Upper bound on total coal produced (for export) -- United States

- Inland transportation cost--United States

- Energy Information Administration, SEATRAN submodel (of ICTM-2)

- Ocean transportation costs (for direct and canal routes)

- Energy Information Administration definitions of coal types

- Btu content of each coal type. 
General Output Descriptions: The output of the ICTM consists of detailed forecasts of key attributes of the international coal market in projected case years. The main outputs are reports on: coal exports and imports by region and coal type and coal trade from origin to destination, market shares, prices, and type of coal.

\section{Computing Environment:}

- Hardware Used: IBM 3084 or $360 / 370$ (or equivalent)

- Operating System: OS/MVS MP or OS or VS

- Language/Software Used: MDMS30 and NLHLP30 to create the object module; a short adjunct program requires the FORTRAN 77 compiler.

- Memory Requirement: $900 \mathrm{~Kb}$

- Storage Requirement: 3350 disk -- Approximately 6 tracks for the source programs, 33 tracks for the object (OBJ) module, 30 tracks for the load module, 400 tracks to unload the archive tape.

- Estimated Run Time: On an IBM 3084QX operating under MVS/XA, $30 \mathrm{CPU}$ seconds

- Special Features: Nonlinear extension of LP algorithm.

Independent Reviews Conducted:

- Intemational Coal Trade Model Documentation Review, Edward Hillsman, November 1983, Independent Expert Reviewer.

- Model Quality Audit was conducted by the Office of Statistical Standards, June 1989.

- Independent Expert Review was conducted by Dr. Denny Ellerman, June 1989.

Status of Evaluation Efforts by Sponsor: None.

\section{International Nuclear Model - Personal Computer (PCINM)}

Description: The International Nuclear Model - Personal Computer (PCINM) is a deterministic model used by the Energy Information Administration (EIA) to project domestic and international nuclear energy requirements. The EIA uses the PCINM to project aggregate spent fuel discharges, fuel cycle requirements, on-line and year-end capacities, and electricity generation for domestic and foreign nuclear reactors on an annual basis, using a simple accounting technique. PCINM can be used to produce projections for any country in the world for any specified time period. Currently eight (8) different country groups are being projected through the year 2010. To produce the forecasts, EIA develops a set of operational assumptions for capacity factors, full power days, reactor size, and reload quantities. These assumptions are derived statistically from historical operating data and from utilities' projected fuel management schemes and are incorporated into fuel management plans. Estimates of nuclear fuel cycle trends are determined by surveying utilities, fuel vendors, and other industry experts.

Last Model Update: July 1992.

Part of Another Model? No.

Model Interfaces: None.

Sponsor:

- Oifice: Coal, Nuclear, Electric and Alternate Fuels

- Division: Analysis and Systems Division

- Branch: Supply Analysis Branch, EI-532

- Model Contact: Diane L. Jackson

- Telephone: 202-254-5536

Documentation:

- Nuclear Fuel Cycle Requirements System, Benchmarking Procedures Report; Z, Inc., January 15, 1992

- Nuclear Fuel Cycle Requirements System, Program Specifications for Fuel Cycle Requirements Forecasting; Z, Inc., August 23, 1991

- Nuclear Fuel Cycle Requirements System, Phase I Development; Z, Inc., March 1, 1991

- International Nuclear Model: Volume 1, Model Overview; David A. Andress, March 1985

- International Nuclear Model: Volume 2, Database Relationships; David A. Andress, April 1985

- International N aclear Model: Volume 3, Program Description; David A. AnJress, June 1985.

Archive Media and Installation Manual(s):

- PCINM92 - for the World Nuclear Capacity and Fuel Cycle Requirements 1992.

Purpose: PCINM provides fuel cycle forecasts for uranium and enrichment service requirements, spent fuel discharges and annual nuclear electricity generation projections, and on-line and year-end capacities.

Energy System Described by Model: Electricity generation by nuclear-powered units. 


\section{Coverage:}

- Geographic: Any country or predefined country group (user specified, limited to data availability)

- Time Unit/Frequency: Specified by user or on an annual basis, no limitation on number of years

- Product(s): Nuclear fuel cycle requirements, spent fuel discharges, electrical generation projections, and on-line and year-end capacities

- Economic Sector(s): Electric commercial utility sector with emphasis on the nuclear fuel-cycle requirements.

\section{Modeling Features:}

- Model Structure: Deterministic model based upon factual input data and scenario assumptions. Derives cycle-by-cycle, reactor-by-reactor interim values to determine final annual projections of uranium and enrichment requirements, spent fuel discharges, electricity generation, and on-line and year-end capacities.

- Modeling Technique: Accounting method on an annual basis--there is only one correct solution for a given set of input data and selected scenario assumptions.

- Special Features: Flexible analysis of fuel management capabilities.

\section{Non-DOE Input Sources:}

- Nuclear Assurance Corporation, Norcross, GA

- U308 Status Report; Enrichment Status Report; Discharge Fuel/Reprocessing Report

- Foreign coresize, capacity factors, full power days, reload fraction, U235 enrichment assay

- Nuclear Regulatory Commission

- Domestic reactor capacity factors, nominal capacity, reload fraction and U235 enrichment assay.

\section{DOE Data lnput Sources:}

\section{Forms and Publications:}

- Department of Energy, Energy Information Administration, Form RW-859, "Nuclear Fuel Data"

- Electric utility survey data used to set starting inventory levels of spent fuel
- Survey data used to determine and update reactor near-term operating characteristics

- Department of Energy, Office of the Deputy Assistant Secretary for Uranium Enrichment

- Tails assay estimates

Models and Other:

- Energy Information Administration, World Integrated Nuclear Evaluation System, WINES-PC

- Projects long-term nuclear generating capacities worldwide.

General Output Descriptions: Reports and report files identifying spent fuel, fuel cycle requirements, and electric generation, on-line and year-end capacities, annualized by country or domestic region by reactor type over a userspecified projection period.

Computing Environment:

- Hardware Used: IBM compatible 386, VGA monitor, $40 \mathrm{Mb}$ hard drive, math coprocessor, printer

- Operating System: DOS 3.3 or higher

- Language/Software Used: PC SAS, CLIPPER (version 5.01), dBASE IV

- Memory Requirement: 7 Mb RAM

- Storage Requirement:

- for Data bases, Program Library, and CLIPPER EXE files $=2 \mathrm{Mb}$

- for SAS program and command files = TBD upon final benchmarking results

- for temporary and memory files $=$ to be determined upon final benchmarking results

- Estimated Run Time: approximately 10 minutes per scenario

- Special Features: None.

Independent Reviews Conducted: None.

Status of Evaluation Efforts by Sponsor: On-going. 


\section{Levelized Nuclear Fuel Cycle Cost Model (LNFCC-PC)}

Description: LNFCC-PC computes an electric utility's levelized nuclear fuel cost. The code computes quantities of fuel cycle services and levelized direct costs, which include the carrying charges accounting for the time value of money. All fuel-cycle services from natural uranium purchased through waste disposal are covered.

Last Model Update: April 1986.

Part of Another Model? No

Model Interfaces: As required for particular application.

Sponsor:

- Office: Office of Integrated Analysis and Forecasting

- Division: Energy Supply and Conversion Division

- Branch: Coal, Uranium and Renewable Fuels Analysis Branch, EI-822

- Model Contact: Laurence Sanders

- Telephone: 202-586-2049

Documentation:

- Energy Information Administration, Levelized Nuclear Fuel Cycle Cost Model User's Guide, MDR/ES/81, (Washington, DC, June 1982).

- Energy Information Administration, Levelized Nuclear Fuel Cycle Cost (LNFCC-PC) Lotus 1-2-3 Spreadsheet Documentation, Installation and Operating Instructions, Laurence Sanders (Washington, DC, April 1986).

Archive Media and Installation Manual(s):

- LNFCC86 - Annual Energy Outlook 1986

- $\quad$ LNFCC90 - Annual Energy Outlook 1990.

Purpose: LNFCC-PC computes nuclear fuel cost, given uranium prices, fuel processing prices, tails assays, and reactor operations data.

Energy System Described by Model: LNFCC-PC covers the entire nuclear fuel cycle.

\section{Coverage:}

- Geographic: Constrained to light water reactors (LWRs) United States and foreign

- Time Unit/Frequency: As needed for annual reports
- Product(s): Nuclear fuel costs

- Economic Sector(s): Electric utilities.

Modeling Features:

- Model Structure: Equations described in model documentation

- Modeling Technique: Deterministic

- Special Features: Lotus 1-2-3 electronic spreadsheet.

Non-DOE Input Sources:

- NUEXCO,Monthly Report on the NuclearFuel Market, (Denver, CO)

- Uranium Price

- Conversion price

- Fabrication price

- Enrichment price

- Unit cost of waste disposal

- Data Resources, Inc., Utility Cost of Finance for Debt, Preferred Equity, and Common Equity

- Utility cost of capital

- Lag for revenue collection

- Standard and Poor's Compustat Services, Inc., The Compustat Tapes, Denver, $\mathrm{CO}$, and subsequent releases

- Utility cost of capital

- Lag for revenue collection.

\section{DOE Data Input Sources:}

\section{Forms and Publications:}

- Energy Information Administration, World Nuclear Fuel Cycle Requirements, DOE/EIA-0436, (Washington, DC, September 1988)

- Thermal rating of nuclear plant

- Electrical ratings

- Cycle length

- Full power days per cycie

- Fresh fuel assay 
- Discharge burnup

- Batch fraction

- Process loss

- Lead ti ne

Models and Other:

- Office of the Assistant Secivtary for Nuclear Energy, Office of the Deputy Assisıan! Secretary for Uranium Enrichment

- Enrichment contracting turns (base enrichment price, 'VTAO surcharge, enrichınent tails assay).

General ( )utput Descriptions: LNFC.C.-PC is used to estimate and interpret the cost of commercial nuclear reactor fies.

Computing Environment:

- Hardware Used: IBM-compatihle persomal computer

- Operating System: MS DOOS

- I anguage/Sofitware Used: I.olus 1-2-3, Version 1.0

- Menory Ki yuir:nent: $(2+1) \mathrm{Kh}$

- Storage Requirer:ent: $27 \mathrm{Kh}$

- Estimated Run Time: ()n an IBM AT, 30-40 C.PU seconds

- Special Features: Interactive.

Independent Review Conducted: Nonc.

Status of Evaluation Efforts by Sponsor: None.

\section{Low Income Household Energy Assistance Program (LIHEAP)}

Description: LIIHEAP is a set of State-level regression equations used to project State residential energy prices for the current year and sne future year, based on nationallevel residential price projections produced for the Energy Information Administration's (EIA) Shon-Tent Energy Outlook. L.IHE:AP produces 51 separate sets of projec tions of residential prices (50) for each State and 1 for the District of (olumbia), including prices for electricity, natur... gas, heating oil, liquefied petroleum gas (L.PG-propane), kerosene and coal. Less than 51 projections are available where historical information for a State is nonexistent or unavailable. The State price projecaons trom LIHEAP are published annually in the EIA service report, State Enerzi Price Projections for the Residential Sector.
Last Medel Update: August 1992.

Part of Another Model? No.

Model Interfaces: The model utilizes annualized forecasts from the Short-Term Integrated Forecasting System (STIFS) as reference inputs to the State-level forecasting equations.

Sponsor:

- Office: Office of Energy Markets and End Use

- Division: Energy Markets and Contingency Information Division

- Branch: Short-Term Forecasting and Contingency Branch, EI-621

- Model Contact: David Costello

- Telephone: 586-1468

Documentation: Energy Information Administration, State Energy Price Projections for the Residential Sector 1992, Appendix (Wash:ngton, DC., September 1992)

Archive Media and Installation Manual(s): LIH 192 - Low Income Household Energy Assistance Program, archived for the State Energy Price Projections for the Residential Sector 1992-1993 and for purposes of documentation.

Purpose: The purpose of LIHEAP is to generate the model State-level residertial price estimates that are consistent with historical trends and which accurately reflect the relative per-unit cost of energy delivered to residences. The prices are used by the Administration ror Children and Families, U.S. Department of Health and Human Services, to determine the allocation formula to be used in the event that Congress funds low income energy assistance above a bassiline amount.

Energy System Described by Model: State-level residential entigy prices of the residential sector, including prices for electrici:y, natural gas, heating oil, LPG (propane), kerosene and coal.

\section{Coverage:}

- Geographic: 50 U.S. States and the District of Columbia

- Time Unit/Frequency: Run annually with 3-year projections

- Product(s): Energy prices

- Economic Sector(s): Residential 
Modeling Features:

- Model Structure: The model consists of approximately 300 separate regression equations for Statelevel residential prices, each of which includes as the principal determinant the corresponding nationallevel residential price. For some States, little or no information on some prices exists, and in these cases, either no estimates are made or a simple simulation rule is applied to forecast State-level prices.

- Modeling Technique: The equations are estimated by ordinary least squares (OLS), and in some instances a first-order autoregressive error process is estimated using an iterative nonlinear estimation technique. Projections are obtained from the model by separately simulating each State-level equation, given nationallevel price forecasts and information on lagged values of the model variables needed to work through the autoregressive error process. Selective final adjustments are made to the projections in a spreadsheet if resulting projections are out of line with recent historical trends or if a calculated weighted average of the State-level projections are more than 5 percent different from the national-level price from which they were derived.

\section{Non-DOE Input Sources:}

- Not applicable.

\section{DOE Data Input Sources:}

Forms and Publications:

- Energy Information Administration, State Energy Price and Expenditures Repon 1990

- State-level residential price history (1970-1990)

- National-level residential energy prices

- Energy Information Administration, State Energy Data System

- State-level Btu conversion factors

- State-level residential sector energy consumption weights

Models and Other:

- Energy Information Administration, Short-Term Integrated Forecasting System

- National-level residential energy prices.

Genersl Output Descriptions: State-level residential sector energy prices for e: :ctricity, natural gas, heating oil, LPG (propane), kerosene and coal.
Computing Environment:

- Hardware Used: IBM 370/3084 and IBM PC-Compatible

- Operating System: Joint mainframe and PC system

- Language/Software Used: SAS Version 6.0; Lotus 12-3, Version 2.2

- Memory Requirement: $4000 \mathrm{~Kb}$ - mainframe; $250 \mathrm{~Kb}$ for PC memory

- Storage Requirement: 3500 Blks - mainframe; $300 \mathrm{~Kb}$ for PC

- Estimated Run Time: 240 CPU seconds

- Special Features: None.

Independent Reviews Conducted: None.

Status of Evaluation Efforts by Sponsor: None.

$$
\begin{aligned}
& \text { Market Penetration Model for } \\
& \text { Active and Passive Solar } \\
& \text { Technologies (MPSOLAR-PC) }
\end{aligned}
$$

Description: MPSOLAR-PC for active and passive solar technologies was developed to project the potential of these systems to displace primary energy from the present up to the year 2030. 'The model provides projections in 5-year increments for nine solar technologies: Residential and Commercial Active Solar Water Heating; Residential and Commercial Active Solar Combined Space and Water Heating Systems; Residential and Commercial Passive Solar Space Heating; Residential and Commercial Active Solar Space Cooling Systems; and Commercial Daylighting.

Last Model Update: October 1991.

Part of Another Model? None.

Model Interiaces: A spreadsheet named SUMMARY is set up to import the results of MPSOLAR for each of the 4 Census regions, and then to disdggregate these results into results for each of the $10 \mathrm{DOE}$ regions.

\section{Sponsor:}

- Office: Office of Integrated Analysis and Forecasting

- Division: Energy Supply and Conversion Division

- Branch: Coal, Uranium and Renewable Fuels Analysis Bianch, EI-822

- Model Contact: Roger Diedrich 
Documentation: Science Applications International Corporation, Market Penetration Model for Active and Passive Solar Technologies Documentation, prepared for the Energy Information Administration (Washington, DC, December 31, 1990).

Archive Media and Installation Manual(s):

- MPM91 - archived for the Annual Energy Outlook 1991

- MPM92 - archived for the Annual Energy Outlook 1992

Purpose: To project the potential of active and passive solar technologies to displace primary energy from the present up to the year 2030 .

Energy System Described by Model: The potential displacement of primary energy resources from installation of active and passive solar systems on new and existing commercial and residential buildings in the United States.

\section{Coverage:}

- Geographic: Groups of DOE regions--1, 2, and 3;5 and $7 ; 4$ and $6 ;$ and 8,9 , and 10

- Time Unit/Frequency: 1989 and 1990 through 2030 in 5-year increments

- Product(s): Active water heating, active space and water heating, passive heating, active cooling, and daylighting

- Economic Sector(s): Commercial and residential buildings.

\section{Modeling Features:}

- Model Structure: Values of the various parameters are displayed in successive matrices, with a column for each year and a row for each region.

- Modeling Technique: Successive tables of values calculated from previously entered or calculated tables of values.

- Special Features: None.

\section{Non-DOE Input Sources:}

- Science Applications International Corporation, Renewable Energy Technology Characterizations, prepared for DOE's National Energy Strategy

- Revised solar system costs
- Science Applications International Corporation, Air Conditioning Technology and Markets Assessment, prepared for Southern California Edison Company

- Function defining relationships between market penetration and payback period

- Technology acceptance diffusion factors

- Interviews by Science Applications International Corporation personnel

- Technology acceptance diffusion factors

- F-Chart (F-Chart Software, Middleton, WI) and TRNSYS simulations performed for the Solar Buildings Technology Performance Office

- Solar system performance--active solar water heating, active solar combined space and water heating, passive solar space heating, commercial daylighting

- Analyses performed by Solar Energy Research Institute (SERI), Golden, CO

- Solar system performance--active solar space cooling.

DOE Data Input Sources:

Forms and Publications:

- Energy Information Administration, Annual Energy Outlook 1989, DOE/EIA-0383(89) (Washington, DC, January 1989)

- Energy use by end use

- Energy Information Administration, Nonresidential Buildings Energy Consumption Survey: Characteristics of Commencial Buildings 1986, DOE/EIA-0246(Washington, $\mathrm{DC}$, October 1988)

- Energy use by end use--commercial

- Energy Information Administration, Residential Energy Consumption Survey: Housing Characteristics 1987, DOE/EIA-0314 (Washington, DC., June 1989)

- Energy use by end use--residential

- Energy Information Administration, Annual Energy Review 1988, DOE/EIA-0384(88) (Washington, DC, June 1989)

- Energy use by end use

- Energy Consenvation Multi-Year Plan FY 1990- 1994 
- Energy use by end use

- Solar Buildings Technology Program Office, National Solar Buildings Technology Program, Multi-Year Program Plan FY 1990 - 1994

- Solar system costs

- Energy Information Administration, Solar Collector Manufacturing Activity Report, DOE/EIA-0714 (Washington, DC, December 1991)

- Active solar collector production and the area of solar collectors sent to each State in the United States, 1973 - 1987 (used in estimating energy use by end use)

Models and Other: Energy Information Administration, AEO Forecasting System base case

- Conventional energy prices.

General Output Descriptions: Simple payback periods, solar systems market share, annual energy contribution of solar systems.

\section{Computing Environment:}

- Hardware Used: IBM-compatible personal computer

- Operating System: MS DOS

- Language/Software Used: Lotus 1-2-3, Version 3.1

- Memory Requirement: 2 Mb RAM

- Storage Requirement: Approximately $115 \mathrm{~K}$ for each case (base, conventional energy tax, accelerated renewables) and region

- Estimated Run Time: Essentially instantaneous (spreadsheet automatically recalculates when changes in values of input data are entered)

- Special Features: None.

Independent Reviews Conducted: None.

Status of Evaluation Efforts by Sponsor: None.

\section{Market Penetration Model for Ground Water Heat Pump Systems (MPGWHP-PC)}

Description: MPGWHP-PC for ground water heat pump systems was developed to project the potential of these systems to displace primary energy from the present up to the year 2030. The model piovides projections in 5-year increments for 4 aggregated groups of the $10 \mathrm{DOE}$ regions.
Last Model Update: October 1991.

Part of Another Model? No.

Model Interfaces: None.

Sponsor:

- Omce: Office of Integrated Analysis and Forecasting

- Division: Energy Supply and Conversion Division

- Branch: Coal, Uranium and Renewable Fuels Analysis Branch, EI-822

- Model Contact: Roger Diedrich

- Telephone: 202-586-0829

Documentation: Science Applications International Corporation, Market Penetration Model for Ground Water Heat Pump Systems Documentation, prepared for the Energy Information Administration (Washington, DC, December $31,1990)$

Archive Media and Installation Manual(s):

- MPM91 - archived for the A nnual Energy Outlook 1991

- MPM92 - archived for the Annual Energy Outlook 1992

Purpose: To project the potential of ground water heat pump systems to displace primary energy from the present up to the year 2030 .

Energy System Described by Model: The potential displacement of primary energy resources from installation of ground water heat pump systems in new and existing commercial and residential buildings in the United States.

\section{Coverage:}

- Geographic: Groups of DOE regions--1, 2, and 3; 5 and $7 ; 4$ and 6 ; and 8,9 , and 10

- Time Unit/Frequency: 1990 through 2030 in 5-year increments

- Product(s): Building heating and cooling

- Economic Sector(s): Commercial and residential buildings.

Modeling Features:

- Model Structure: Values of the various parameters are displayed in successive matrices, with a column for each year and a row for each region 
- Modeling Technique: Successive tables of values calculated from previously entered or calculated tables of values

- Special Features: None.

\section{Non-DOE Input Sources:}

\section{- R.S. Means, 1990 Mechanical Cost Data}

- Various HVAC (heating, ventilation and air conditioning) component prices (used in deternining energy cost savings)

- Jim Bose, University of Oklahoma, Executive Director of the International Ground Source Heat Pump Association, and various ground loop installers

- Ground water heat pump system costs

- Water Furnace International

- Simulations used to estimate residential energy use (used in determining energy cost savings)

- Dan Ellis, President of Water Furnace International

- Technology acceptance factors

- Revised ground water heat pump production data

- American Socicly of Heating, Refrigeration and Air Conditioning Engineers

- Algorithms used in Water Furnace International simulations

- Science Applications International Corporation, Air Conditioning Technology and Markets A ssessment, prepared for Southern California Edison Company

- Function defining relationships between market penetration and payback period

- Interviews by Science Applications International Corporation personnel

- Technology acceptance factors.

DOE Data Input Sources:

Forms and Publications:

- Energy Information Administration, Annual Energy Outlook 1989, DOE/EIA-0383 (Washington, DC, January 1989)

- Energy use by end use
- Energy Information Administration, Annual Energy Review 1988, DOE/EIA-0384 (Washington, DC, June 1989)

- Energy use by end use

- Energy Information Administration, Nonnesidential Buildings Energy Consumption Sunvey: Characteristics of Commercial Buildings 1986, DOE/EIA-0246 (Washington, DC, October 1988)

- Energy use by end use--commercial

- Energy Information Administration, Residential Energy Consumption Survey: Housing Characteristics 1987, DOE/EIA-0314 (Washington, DC, June 1989)

- Energy use by end use--residential

- Energy Consenvation Multi-Year Plan, FY 1990-1994

- Energy use by end use

Models and Other:

- Federal Energy Management Program, ASEAM (A Simplified Energy Analysis Method) simulation program

- Simulations used to estimate commercial energy use (used in determining energy cost savings)

- Energy Information Administration, AEO Forecasting System base case

- Conventional electricity prices (used in determining energy cost savings)

- Lew Pratsch, Renewable Energy Office, Renewable Energy Technologies Division, Geothermal Technology Branch

- Ground water heat pump production data.

General Output Descriptions: Simple payback periods, market share for ground water heat pump systems, and energy contribution potential of ground water heat pump systems.

Computing Environment:

- Hardware Used: IBM-compatible personal computer

- Operating System: MS DOS

- Language/Software Used: Lotus 1-2-3, Version 3.1

- Memory Requirement: 2 Mb RAM 
- Storage Requirement: Approximately $225 \mathrm{~Kb}$ for each case (base, conventional energy tax, accelerated renewabies)

- Estimated Run Time: Essentially instantaneous (spreadsheet automatically recalculates when changes in values of input data are entered)

- Special Features: None.

Independent Reviews Conducted: None.

Status of Evaluation Efforts by Sponsor: None.

\section{Market Penetration Model for Resi- dential Rooftop Photovoltaic Sys- tems (MPRESPV-PC)}

Description: MPRESPV-PC for residential rooftop photovoltaic systems was developed to project the potential of these systems to displace primary energy from the present up to the year 2030. The model provides projections in 5 -year increments for 4 aggregated groups of the $10 \mathrm{DOE}$ regions.

Last Model Update: October 1991.

Part of Another Model? No.

Model Interfaces: None.

Sponsor:

- Omice: Office of Integrated Analysis and Forecasting

- Division: Energy Supply and Conversion Division

- Branch: Coal, Uranium and Renewable Fuels Analysis Branch, EI-822

- Model Contact: Roger Diedrich

- Telephone: $202-586-0829$

Documentation: Science Applications International Corporation, Market Penetration Model for Residential Rooftop Photovoltaic Systems Documentation, prepared for the Energy Information Administration (Washington, DC, December 31, 1990)

Archive Media and Installation Manual(s):

- MPM91 - archived for the A nnual Energy Oittlook 1991

- MPM92 - archived for the Annual Energy Outlook 1992.

Purpose: To project the potential of residential rooftop photovoltaic systems to displace primary energy from the present up to the year 2030.
Energy System Described by Model: The potential displacement of primary energy resources from installation to photovoltaic systems on rooftops of new and existing residences in the United States.

\section{Coverage:}

- Geographic: Groups of DOE regions--1 and 2; 3 and $5 ; 4,7$, and $10 ;$ and 6,8 , and 9

- Time Unit/Frequency: 1990 through 2030 in 5-year increments

- Product(s): Electricity

- Economic Sector(s): Residential buildings.

Modeling Features:

- Model Structure: Values of the various parameters displayed in successive matrices, with a column for each year and a row for each region

- Modeling Technique: Successive tables of values calculated from previously entered or calculated tables of values

Non-DOE Input Sources:

- DRI/McGraw-Hill Energy Review, Winter 1989-1990

- Residential electricity demand--through 2010

- Science Applications International Corporation, Renewable Energy Technology Characterizations, prepared for DOE's National Energy Strategy

- Photovoltaic electricity costs

- Science Applications International Corporation, Air Conditioning Technology and Markets A ssessment, prepared for Southern California Edison Company

- Function defining relationships between market penetration and payback period

- Interviews by Science Applications International Corporation personnel

- Technology acceptance factors

- Gary Jones, Sandia National Laboratory

- Data used to estimate photovoltaic electricity costs.

DOE Data Input Sources:

Forms and Publications: 
- Energy Information Administration, Solar Collector ManufacturingActivity Repon, DOE/EIA-0714 (Washington, DC, December 1989)

- Residential photovoltaic system shipments

\section{Models and Other:}

- Energy Information Administration, AEO Forecasting System base case

- Conventional electricity costs

- Energy Information Administration, Office of Coal, Nuclear, Electric and Alternate Fuels

- Residential electricity demand--beyond 2010

- Conversion efficiency.

General Output Descriptions: Simple payback period, photovoltaic system market share, new and retrofit primary electrical energy market, and cumulative energy contribution potential of residential photovoltaic systems by annual production method, market penetration model, and combined method.

\section{Computing Environment:}

- Hardware Used: IBM-compatible personal computer

- Operating System: MS DOS

- Language/Software Used: Lotus 1-2-3, Version 3.1

- Memory Requirement: $2 \mathrm{Mb}$ RAM

- Storage Requirement: Approximately $65 \mathrm{~Kb}$ for each case (base, conventional energy tax, accelerated renewables)

- Estimated Run Time: Essentially instantaneous (spreadsheet automatically recalculates when changes in values of input data are entered)

- Special Features: None.

Independent Reviews Conducted: None.

Status of Evaluation Efforts by Sponsor: None.

\section{Mini-Macroeconomic Personal Computer Model (PCMAC)}

Description: PCMAC forecasts 37 macroeconomic variables and 11 industrial outputs. Variables include, anong others, real GNP, the GNP deflator, real disposable income, the unemployment rate, housing starts, industrial output (at an 11-sector disaggregation), the interest rate on corporate bonds, and the mortgage rate. PCMAC name retained although model has been moved to EIA mainframe.

Last Model Update: December 1991.

Part of Another Model? PCMAC was designed to be used as the interactive macroeconomic model of the Intermediate Future Forecasting System.

Model Interfaces: Takes computed energy prices from IFFS/GAMS, calculates macroeconomic impacts on basecase forecasts, calculates industrial output impacts on base-case forecasts, and returns the impacted forecasts.

\section{Sponsor:}

- Office: Office of Integrated Analysis and Forecasting

- Division: Energy Demand and Integration Division

- Branch: International Economics and Integrated Forecasting Branch, EI-812

- Model Cuntact: Ronald Earley

- Telephone: $202-586-1398$

Documentation: Energy Information Administration, $P C$ AEO Forecasting Model for the Annual Energy Outlook 1991, Model Documentation (Section 6, Macroeconomic Impacts), DOE/EIA-M036(90) (Washington, DC, March 1990), and technical notes.

Archive Media and Installation Manual(s): Archived on EIA mainframe as C.N6121.prj.iffs.fortrn.mac.D 1210911.

Purpose: PCMAC furnishes base-case economic forecasts consistent with base-case world oil prices. It also furnishes the mechanisms for adjusting these base forecasts in response to alternative energy price scenarios.

Energy System Descrilsed by Model: PCMAC generates annual forecasts of important macroeconomic and industrial output variables used by the energy supply and demand subinodels of the Annual Energy Outlook Forecasting System.

Coverage:

- Geographic: National with disposable income disaggregated into four Census regions

- Time Unit/Frequency: Annual, 1990 through 2010

- Product(s): None

- Economic Sector(s): 37 macroeconomic variables and 11 industrial output sectors.

Modeling Features: 
- Model Structure: Linear approximation version of the Data Resources, Inc., Compact Quarterly, Model of the U.S. Economy. Reduced form representation of the DRI Input-Output Model for the for the PC.

- Modeling Technique: Estimated on simulation data, using ordinary least squares regression techniques.

- Special Features: Constructed in VS FORTRAN

Non-DOE Input Sources: Data Resources, Incorporated

- Baseline forecast values of key macroeconomic variables obtained from simulations of the DRI Compact Quarterly Macroeconomic Model. The simulations are based on EIA economic and world oil price assumptions. A partial list of data includes:

- Real GNP

- GNP price deflator

- Real disposable income

- Unemployment rate

- Housing starts

- Industrial output for 11 sectors

- Wholesale price index for fuel and power.

DOE Data Input Sources:

Forms and Publications:

- Energy Information Administration, AEO Forecasting base case

- Domestic oil, gas, coal and refining data from results of preliminary integrated AEO runs

Models and Other:

- Energy Information Administration, Annual Energy Outlook Forecasting System

- Fuel prices

- Industrial output

- Population

- Personal consumption expenditures

- Gross private fixed investment

- Change in business inventories

- Government purchases of goods and services
- Exports

- Imports

- Real U.S. GNP

- Full employment level of real GNP

- Personal disposable income

- Unemployment rate

- Implicit GNP price deflator

- Consumer price index

- Implicit import and export price deflators

- U.S. trade-weighted exchange rate

- Wholesale price index

- Housing starts

- Manufacturing capacity utilization

- Unit sales of automobiles

- Interest rate on corporate bonds

- Mortgage rate

- Yield on AA utility bonds

- Employment cost index

- Unit labor cost index

- Federal tax on motor gasoline

- Employment, non-agricultural establishments

- Net capital stock.

General Output Descriptions: Total of $\mathbf{3 7}$ macroeconomic variables, plus industrial output for 11 sectors.

Computing Environment:

- Hardware Used: IBM 3084 QX or $360 / 370$ (or equivalent')

- Operating System: MVS/XA

- Language/Software Used: VS FORTRAN

- Memory Requirement: $1024 \mathrm{~Kb}$

- Storage Requirement: 3380 disk, $350 \mathrm{~Kb}$ 
- Estimated Run Time: $1 \mathrm{CPU}$ minute stand-alone mode

- Special Features: None.

Independent Reviews Conducted: Independent Expert Review by Victor Zarnowitz, Oak Rid ge National Laboratory, July 1988.

Status of Evaluation Efforts by Sponsor: Reconciled critique by Zarnowitz.

\section{National Coal Model (NCM)}

Description: NCM projects coal production by State; coal transportation flows; and fuel consumption by electric utilities, based on specified levels of electricity consumption, existing and planned generating capacity, the economics of electricity generation, and nonutility demand for coal. The NCM is a highly disaggregated coal supply and utility model. Coal demands in each of 44 regions are met via a transportation network from existing and new mines in 31 supply regions. Flue gas desulfurization technology is internally represented and both sulfur dioxide and other emissions are reported.

Last Model Update: August 1991.

Part of Another Model? National Utility Financial Statement (NUFS) Model can be used as an extension to NCM.

Model Interfaces: The NCM uses as input data supply curves produced by the RAMC model and transportation costs produced by the Coal Supply and Transportation Model. Levels of electricity demand and nonutility coal demand used in the NCM are obtained from forecasts produced by the Intermediate Future Forecasting System (IFFS) for the Annual Energy Outlook.

\section{Sponsor:}

- Ofince: Office of Integrated Analysis and Forecasting

- Division: Energy Supply and Conversion Division

- Branch: Coal, Uranium and Renewable Fuels Analysis Branch, EI-822

- Model Contact: Robert Manicke

- Telephone: 202-586-2038

\section{Documentation:}

- Energy Information Administration, National Coal Model: Executive Summary, DOE/EIA-0325, (Washington, DC, April 1982)
- Energy Information Administration, National Coal Model, Model Description and Formulation, DOE/EIA-0428, (Washington, DC, September 1983)

- Energy Information Administration, National Coal Model (Versions 6 and 7) Users Manual, DOE/EIAM027 (Washington, DC, March 1988)

- Energy Information Administration, National Coal Model (Versions 6 and 7) Software Manual, DOE/EIAM025 (Washington, DC, January 1988)

- Energy Information Administration, National Coal Model Users Manual, DOE/EIA-0427, (Washington, DC, September 1983).

- Energy Information Administration, Documentation of Data Inputs to the National Coal Model, Kilkeary, Scott Associates, DOE/EI-11857-1, (Washington, DC, April 1983).

- Energy Information Administration, Mathematical Structure and Computer Implementation of the $\mathrm{Na}$ tional Coal Model (Version 4), DOE/EI-10128-2, (Washington, DC, January 1982).

Archive Media and Installation Manual(s):

- Computer runs used in the Analysis Report entitled, Impacts of the Proposed Clean A ir Act A mendments of 1982 on the Coal and Electric Utility Industries, are archived on NC.M4. This is also consistent with the existing NC.M4 documentation.

- NCM484 - Acid Rain Study 1984

- NCM 585 - for Version 5 of the model

- NCM8 - archived for the Annual Energy Outlook 1991

- NCM892 - archived for the 1992 Electric Market Model.

Purpose: The NCM is designed to analyze the impact of changing market conditions on the quantity and quality of coal consumed. The representations embodied in the NC.M emphasize the role of the electric utility industry as the principal consumer of coal and the impact of legislation concerned with sulfur oxides released from coal combustion on the quantity and character of coal consumed by electric utilities.

Energy System Descrilsed by Model: The NCM describes the regional distribution of coal production and the quantity and quality of coal required to satisfy regionally disaggregated demands for steam and metallurgical coal. Nonutility demands for steam and metallurgical coal are exogenous to the model. The quantity and quality of coal demanded byelectric utilities is determined by the dispatch of generating units within the NCM to meet exogenous 
regional demands for electricity. Regional production of coal is determined from long-run supply curves produced by the Resource Allocation and Mine Costing (RAMC) model from engineering based estimates of production costs.

\section{Coverage:}

- Geographic: The NCM consists of 31 supply regions and 44 demand regions within the continental United States.

- Time Unit/Frequency: Any year for which input data are available, generally, 1995, 2000, 2005, and 2010

- Product(s): Coal and electricity

- Economic Sector(s): Electric utility, coal production and transportation.

Modeling Features:

- Model Structure: Four modules including: Electricity and Nonutility Demand, Electricity Generation and Transmission, Coal Production, and Transportation

- Modeling Technique: The NCM is formulated as a (large) linear programming (LP) problem.

- Special Features: The NCM is specifically designed for the analysis of legislation (and regulation) concerned with sulfur dioxide emissions from electrical generating units. In addition, the effects of environmental, tax, and other policy affecting surface or underground mining of coal can be analyzed by the NCM in conjunction with the RAMC model.

Non-DOE Input Sources:

- ICF, Inc., Coal and Electric Utilities Model Documentation, May 1980.

- Coal types or coal blends

- Capacity factors

- Efficiency of electricity transmission between a pair of demand regions--new transmission

- Capital cost of new transmission capacity

- Intraregional electricity transfer efficiency for a demand region

- Particulate emission rates for existing oil-fired steam turbine generating units

- Sulfur dioxide emission rates
- ICF, Inc., Effects of Altemative New Source Performance Standards (NSPS) Coal-Fired Electric Utility Boilers on the Coal Markets and on Utility Capacity Expansion Plans, June 1978

- Capital charge rate

- Particulate emission rates for old existing coalfired steam generating units and for coal-fired steam generating units without Flue Gas Desulfurization (FGD) subject to a State Implementation Plan (SIP)

- Clean Air Act of 1971 and 1977, and Amendments of 1990

- Binding sulfur dioxide umission ceiling for units nominally subject to the NSPS/revised NSPS, the more stringent of the NSPS/revised NSPS or the emission ceiling established by the relevant SIP

- Clear Air Act Amendments of 1990

- $\quad$ Phase 1 and Phase 2 allowances for sulfur dioxide emissions

- ICF, Inc., Still Further Analyses of Altemative New Source Performance Standards for New Coal-Fired Powerplants, January 1979

- Capital charge rate multipliers

- ICF, Inc., Financial Constraints in Capacity Planning: A National Regulatory Model (NURG), Appendix A, October 1981

- Electricity consumption

- PEI Associates, Regionalized Capital, Operating and Maintenance Cost Estimates for Emission Control Equipment Required for Fossil Steam Power Plants, November 1985

- Heat rate

- Base load operation, maintenance and fuel costs for coal-fired generating units

- Incremental operation and maintenance costs of an FGD system

- Energy and capacity penalties for operation of an FGD system by coal-fired generating units

- Capital cost of an FGD system installed in a coalfired generating unit subject the NSPS or retrofit to an existing coal-fired generating unit subject to an SIP 
- Incremental operating and maintenance cost by load

- Electric Power Research Institute, Technical Assessment Guide, Volume 1: Electricity Supply - 1986, (1986)

- Capital cost of new generating capacity

- Theodore Barry and Associates, Update of Electric Utility Data for the National Coal Model and the Midterm Energy Forecasting System, November 1981.

- Efficiency of electricity transmission between a pair of demand regions--existing transmission

- Bounds on electricity transmission between a pair of demand regions.

DOE Data Input Sources:

Forms and Publications:

- Energy Information Administration, Form EIA-7A, "Coal Production Report"

- Allowable plant capacity additions--coal production adjustment factors

- Coal production

- Energy Information Administration, Form EIA-759, "Monthly Power Plant Report"

- Fuel consumption by utilities

- Electricity generation

- Federal Energy Regulatory Commission, FERC Form 423, "Monthly Report of Cost and Quality of Fuels for Eleci,ic Plants"

- Average Btu content of coal produced adjusted for ash content

- Lower bound on coal shipments from supply to demand regions

- Energy Information Administration, Form EIA-767, "Steam-Electric Plant Operation and Design Report"

- Binding sulfur dioxide emission ceilings for units subject to SIP Categories 1, 2, and 3

- Fuel consumption by utilities

- Electricity generation

- Energy Information Administration, Form EIA-826, "Monthly Electric Utility Sales and Revenue Report with State Distributions"

\section{- Electricity consumption}

- Energy Information Administration, Form EIA-860, "Annual Electric Generator Report"

- Allowable plant capacity additions--incremental generating capacity: coal-fired capacity for NSPS and' revised NSPS units, and combined cycle unit capacity

- Generating unit capacity--nonnuclear capacity

- Binding sulfur dioxide emission ceilings for units subject to SIP Categories 1, 2, and 3

- Energy Information Administration, Annual Energy Outlook 1992, (Washington, DC).

- Metallurgical demand for coal, residential and commercial coal demand, demand for coal for use in industrial boilers and electricity demand

- Annual utility cost deflator

- Percent of total generation in each load segment

- Fuel prices

Models and Other:

- Energy Information Administration, Office of Coal, Nuclear, Electric and Alternate Fuels

- Capital cost of converting an existing (bituminous coal-fired) generating unit without FGD that is subject to dn SIP to bum low-sulfur subbituminous coal

- Energy Information Administration, International Coal Trade Model (ICTM)

- Allowable plant capacity additions--export demand for coal

- Percent of export and metallurgical demand satisfied by metallurgical and steam coals

- Energy Information Administration, Resource Allocation and Mine Costing Model (RAMC)

- Coal supply curves (current annual production, minimum acceptable selling price and proportion of annual production from surface mines)

- Energy Information Administration, Office of Coal, Nuclear, Electric and Alternate Fuels, CONCEPT5 Model, in conjunction with 1983 United Engineers, Inc. data base 
- Capital cost of new coal-fired steam generating unit capacity

- Capital cost of an FGD system installed in a coalfired generating unit subject to the revised NSPS

- Regional capital cost adjustment factors.

General Output Descriptions: The output of the National Coal Model consists of detailed projections of key attributes of the coal and electric utilities for 1990, 1995, 2000, 2005 , and 2010 . The projections are presented in various reports.

\section{Computing Environment:}

- Hardware Used: IBM $3084 Q$ X or 370 (or higher)

- Operating System: MVS/XA

- Language/Software Used: FORTRAN IV and Assembly Language implementing MDMS30 (Model Data Management System 30)

- Memory Requirement: $2048 \mathrm{~Kb}$

- Storage Requirement: 3350 disk -- 700 tracks

- Estimated Run Time: Varies widely due to the modular structure, runs can be expected to take 10-25 CPU minutes on a IBM $3084 Q X$

- Special Features: Modular design and special modeling structure for Versions 5, 6, and 7.

Independent Reviews Conducted: National Coal Model Documentation review conducted by Richard Gordon, April 27, 1983.

Status of Evaluation Efforts by Sponsor: Continuing comparisons with results of CSTM, IFFS, and PC-AEO.

\section{National Utility Financial Statement Model (NUFS)}

Description: NUFS is a regulatory accounting model that projects electricity prices. The model first solves for revenue requirements by building up a rate base, calculating a return on the rate base, and adding the allowed expenses. Next, electric revenues (prices) are calculated based on assumptions regarding regulatory lag. With revenues determined, the model solves for internal cash flow and analyzes the need for external financing to meet necessary capital expenditures. Given these results, the model finally builds up the financial statements and calculates financial ratios. NUFS is normally used in conjunction with the National Coal Model or the Intermediate Future Forecasting System. Inputs to NUFS include forecast capacity expansion plans, operating costs, regulatory environment, and financial data. The outputs include forecasts of income state- ments, balance sheets, sources and uses of funds, revenue requirements, average electricity prices, and other financial ratios.

\section{Last Model Update: April 1988}

Part of Another Model? Intermediate Future Forecasting System (IFFS) and the National Coal Model (NCM)

Model Interfaces: IFFS and NCM

Sponsor:

- Ofince: Office of Integrated Analysis and Forecasting

- Division: Energy Supply and Conversion Division

- Branch: Nuclear and Electricity Analysis Branch, EI821

- Model Contact: Arthur Holland

- Telephone: 202-586-2026

Documentation:

- Documentation of the National Utility Financial Statement (NUFS) Model, ICF, Incorporated, Prepared Under Contract No. DE-AC01-87EI-19801, April 1988.

Archive Media and Installation Manual(s):

- NUFS83 - for the Impact of the Proposed Clean AirAct Amendments

- $\quad$ NUFS84 - for the Acid Rain Study 1984

- NUFSSA84 - for the 1984 stand-alone version of the model

- NUFS85 - for the analysis of proposed tax legislation during July 1985

- NUFSFP - for the Investor-Owned Electric Utilities Study

- NUFS86 - for the Annual Energy Outlook 1986

- NUFS90 - for the Annual Outlook for U.S. Electric Power 1990.

Purpose: NUFS provides projection of financial reports, financial measures, and electricity prices. It is used in the publication of the Annual Energy Outlook, Annual Outlook for Electric Power, and other utility financial reports.

Energy System Described by Model: Financial impacts of electric utilities' plans and operations. 


\section{Coverage:}

- Geographic: National, regional, and disaggregation to a single utility

- Time Unit/Frequency: Annual, the forecast horizon can be of any length up to 50 years

- Product(s): NA

- Economic Sector(s): Private and public electric utilities.

\section{Modeling Features:}

- Model Structure: Finance and accounting

- Modeling Technique: Deterministic

- Special Features: NUFS may be run with changes in the financial side inputs and sensitivities, assuming all other parameters are constant. This allows for flexibility in analyzing a variety of policy issues and options. It can be interfaced with IFFS, NCM, or other electricity production costing models.

\section{Non-DOE Input Sources:}

- Annual reports of utilities submitted to stockholders

- Book value (historical)

- Age

- Generation

- Sales to ultimate consumer (historical)

- Accumulated depreciation

- Outstanding bonds

- Short-term debt

- Common stock

- Preferred stock

- Retained earnings

- Embedded cost of capital (debt and preferred)

- Electric revenues

- Working capital

- Deferred taxes (ITC and income taxes)

- General tax rate
- Securities and Exchange Commission Form 10K

- Book value (historical)

- Age

- Generation

- Sales to ultimate consumers (historical)

- Accumulated depreciation

- Outstanding bonds

- Short-term debt

- Common stock

- Preferred stock

- Retained earnings

- Embedded cost of capital (debt and preferred)

- Electric revenues

- Working capital

- Deferred taxes (ITC and income taxes)

- General tax rate

- Commercial data services (e.g., COMPUSTAT)

- Book value (historical)

- Age

- Generation

- Sales to ultimate consumers (historical)

- Accumulated depreciation

- Outstanding bonds

- Short-term debt

- Common stock

- Preferred stock

- Retained earnings

- Embedded cost of capital (debt and preferred)

- Electric revenues

- Working capital 
- Deferred taxes (ITC and income taxes)

- General tax rate

- Relevant IRS tax law

- Tax life.

DOE Data Input Sources:

\section{Forms and Publications:}

- Federal Energy Regulatory Commission, FERC Form 1, "Annual Report of Major Electric Utilities, Licensees and Others"

- Book value (historical)

- Age

- Generation

- Sales to ultimate consumers (historical)

- Accumulated depreciation

- Outstanding bonds

- Short-term debt

- Common stock

- Preferred stock

- Retained earnings

- Embedded cost of capital (debt and preferred)

- Electric revenues

- Working capital

- Deferred taxes (ITC and income taxes)

- General tax rate

- Energy Information Administration, Form EIA- 412,

"Annual Report of Publicly Owned Electric Utilities"

- Book value (historical)

- Age

- Generation

- Accumulated depreciation

- Outstanding bonds

- Short-term debt
- Common stock

- Preferred stock

- Retained earnings

- Embedded cost of capital (debt and preferred)

- Electric revenues

- Working capital

- Deferred taxes (ITC and income taxes)

- General tax rate

\section{Models and Other:}

- Energy Information Administration, capacity expansion/production models (e.g., Intermediate Future Forecasting System (IFFS), National Coal Model (NCM))

- Length of construction period

- Construction profile

- Book life

- Tax life

- Book depreciation rate

- ERTA tax class

- Investment tax credit rate

- Real escalation rate

- Sales to ultimate consumers (forecast)

- Unit costs (operation and maintenance, and fuel)

- Cost of nuclear fuel

- Revenues from sales for resale

- In service date

- First year in service fraction

- Capacity cost

- Capacity

- Tax basis

- Book value (forecast) 
- CWIP allowed in rate base.

General Output Descyiptions: NUFS output are income statements, balance sheets, sources and uses of funds, construction expenditures, and reporis which contain electricity price data.

\section{Computing Fnvironment:}

- Hardware Used: IBM 370 or equivalent

- Operating System: OS or VS

- Langugge/Sontware "' id: FORTRAiv (the programs creating the objert and load modules use the VS compiler)

- Memory Requirement: Varies with application, ranges from $512 \mathrm{~Kb}$ for a single utility to $2012 \mathrm{~Kb}$ when interfacing with IFFS data base in multiregional application.

- Storaga Requirement: 3380 disk -- 100 tracks permanent, 1000 tracks temporary

- Estimated Run Time: Varies with application; on an IBM 3084 operating under MVS/XA, ranges from less than $5 \mathrm{CPU}$ seconds for a single utility to $40 \mathrm{CPU}$ seconds when interfacing with the IFFS data base in a multiregional application.

- Special Features: None.

Independent Reviews Conducted:

- A Validation Reprrt: An Evaluation of the NUFS Model, Oak Ridge National Laboratory, December 1982.

- Review of National Utility Financial Statement (NUFS) Model Documentation, Cyrus Baghelai, Applied Management Sciences, Inc., November 1983.

Status of Evaluation Efiorts by Spor-ar: None.

\section{Nonutility Generation Supply Model (NUGS)}

Description: The NUGS model is an analytic construct that provides a furecast of nonutility electricity supply including power supplied from cogeneration, independent and affiliated power production, and smals power product ion. The torecast is based on supply potential input and a cimulation of a PURPÁ bidding system to allow selection sf projects. The NUGS is designed to allow an assessment of potential nonutiity electric suppiy to tite power gri iu at a number of levels.

\section{Last Model Update: NA}

Part of Another Model? The NUGS is run as an integrated part of the IFFS. May also be run in stand-alone mole.

Model Interfaces: IFFS and EMM, from which it gets demand data and capacity planning, price, and economic data, respectively.

Sponsor:

- Office: Office of Integrated Analysis and Forecasting

- Division: Energy Supply and Conversion Division

- Branch: Nuclear and Electricity Analysis Branch, EI821

- Model Contact: Patricia Toner

- Telephone: $202-586-2048$

Documentation: Encrgy Information Administration, Model Documentation for the Nonutility Generation Supply Model, DOE/EIA-M043 (Washington, DC, November, 1991).

Archive Media and Installation Manual(s):

- NUGS92 - archived for the Annual Energy Outlook 1992.

Purposc: The NUGS Model is designed to allow an assessment of potential nonutility electric supply to the power grid at a number of levels.

\section{Energy System Described by Model:}

- At the most detailed level, the model can be used to assess alternative technologies as they would be applied either as stand-alone independent or affiliated power production facilities or integral to an industrial facility in a cogeneration application. In this mode, the model assesses the optimal (highest net present value, internal rate of return, etc.) technology designed to meet either the industrial concern's thermal or power requirements. Assessments of technology change, potentia! to switch to cogeneration, etc. can be made as a function of alternative energy price futures and eco1 omic conditions.

- The model can also be used to assess the potential for cogeneration within a utility's service territory, a State or a region. In this mode, the model utilizes a characterization of the industrial base in the defined geographic area, and assesses the likely response to alternative avoided costs and project selection methods that might be employed at the utility or State level, including alternative bidding systems that address nonprice/quantity criteria. 
- By utilizing a broader industrial characterization, the model can be used to assess on a national scale the potential impact of alternative regulatory and economic policies on the penetration of cogeneration and independent power production. Technological advances can aiso be assessed along with alternative energy price futures. This is how the NUGS model is being used when run as part of the IFFS.

\section{Coverage:}

- Geographic: The NUGS is designed to run one plant or a series of plants for a utility, a region, or the Nation.

- Time Unit/Frequency: The NUGS is an annual model and can be run for any year for which there is adequate input data.

- Product(s): Nonutility supply (electric generation and fuel consumption for self-use and sales to utilitics)

- Economic Sector(s): Industrial manufacturing and independent affiliated and small power production nonutility generation.

\section{Modeling Features:}

- Model Structure: NUGS is a detcrministic module that estimates certain engineering cost relationships based on standard empirically derived physical/cost relations taken from the literature and financial measures based on a simplified accouliting framework.

- Modeling Technique: NUGS is based on a goal programming construct (a variation on standard linear programming, techniques) represented by a series of linear equations.

- Special Features: None.

\section{Non-DOE Input Sources:}

- Dun and Bradstreet Major Industrial Plant Database (MIPD), data tape dated March 30, 1990

- Characterizations of the industrial cogeneration (COGEN) and small/independent/affiliated power producer (SPP/IPP/APP) technology base

- The Dun and Bradstreet Cogeneration Model, Draft Documentation, February 1987

- Reference unit capital cost and associated capacity for capital cost calculation

- Dun and Bradstreet Technical Economic Services and

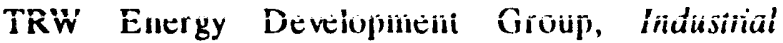
Cogeneration Potential! : 980 - 2000) forApplication of Four Commerially A vailable Prime Movers at the Plant Site, Final Report, Volume I, August 1984
- Percent of capital costs used to estimate base year O\&M costs

- Edison Electric Institute, Capacity and Generation of Nonutility Sources of Energy, $1985-1989$

- $\quad$ Historical data - 1985 - 1989

- Pacific Northwest Laboratory, Cogeneration Handbook for the Textile Industry, February 1984

- Block data defaults (financial, economic and tecnnological data)

- Office of Technology Assessment, Industrial and Commercial Cogeneration, OTA-E-192, February 1983

- Block data defaults (financial, economic and technological data)

- Memo from D. Kleinschmidt, to Lesly A. Goudarzi, Arthur D. Little, Inc., September 5, 1990

- Block data deîaults (Percent of capital costs used to estimate base year O\&M costs (steam turbine) and exponent for capital cost calculation.)

\section{DOE Data Input Sources:}

Forms and Publications:

- Energy Information Administration, Form EIA-867, "Nonutility Power Producer Report"

- 1990 data and planned additions

Models and Other:

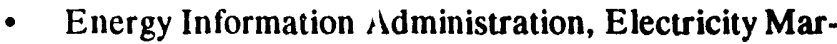
ket Model (EMM)

- Marginal tax rate

- Government bond rate

- Discount rate

- GNP deflator/escalator

- Industrial and utility fuel prices

- Fuel growth rate used to calculate industrial and utility projected fuel prices

- Capacity expansion plan information (committed capacity, in-service year of plant, minimum plant size increment for plant, index for merit order, and levelized variable and fixed costs (in-service year)) 
- Energy Information Administration, Intermediate Future Forecasting System (IFF ${ }_{h}^{\sim}$.

- Industrial electricity demand.

General Output Descriptions: The output generated from the stand-alone NUGS iucludes three output files which provide a detailed accounting of the supply available, the forecast generated (plant by plant), and a summary report by region.

\section{Computing Environment:}

- Hardware Used: IBM $360 / 370$ or equivalent

- Operating System: OS or OS/VS

- Language/Software Used: FORTRAN (VS compiler version 4.1)

- Memory Requirement: Approximately $2000 \mathrm{~Kb}$ for execution of the stand-alone NUGS, $8000 \mathrm{~Kb}$ for the integrated version

- Storage Requirement: 3380 disk--600 tracks

- Estimated Run Time: On an IBM 3084QX operating under MVS/XA, approximately 6CPU minutes for the stand-alone version, $20-60$ minutes for the integrated version.

Independent Reviews Conducted: Independent Expert Review conducted by J. Tschirhart, August 1991.

Status of Evaluation Efirorts by Sponsor: None.

\section{Oil Market Module (OMM)}

Description: OMM is a component of the Intermediate Future Forecasting System (IFFS) which represents the domestic refining and pricing of petroleum products. The OMM uses econometric and accounting methods to model domestic crude oil refining and petroleum product distribution. In addition to projecting product prices, the model assures a material balance for domestic petroleum and provides estimates for the quantities of net product imports and crude inputs to U.S. refineries.

Last Model Update: September 1990.

\section{Part of Another Model? IFFS}

Model Interfaces: OMM can operate as a stand-alone model, or as a model in the AEO Modeling System.

\section{Sponsor:}

- Office: Office of Integrated Analysis and Forecasting

- Division: Energy Supply and Conversion Division
- Branch: Oil and Gas Analysis Branch, EI-823

- Model Contact: Bruce Bawks

- Telephone: 202-586-6579

Documentation:

- Energy Information Administration, Model Documentation for the Oil Market Module of the Intermediate Future Forecasting System, DOE/EIA-M015, (Washington, DC, April 1986)

- Energy Information Administration, Model Documentation Report, The Oil Market Module, DOE/EIAM015, (Washington, DC, September 1990).

Archive Media and Installation Manual(s):

- IFFS90 - for the Annual Outlook for Oil and Gas 1990, Annual Outlook for U.S. Electric Power 1990, and the Annual Outlook for U.S. Coal 1990

- IFFS91 - for the Annual Energy Outlook 1991, Annual Outlook for Oil and Gas 1991, A nnual Outlook for U.S. Electric Power 1991, and the Annual Outlook for U.S. Coal 1991

- $\quad$ IFFS92 - for the Annual Energy Outlook 1992.

Purpose: The Oil Market Module calculates end-use prices for eight product categories by Federal region and consuming sector, as well as an overall petroleum supply/demand balance. This module can be run as part of the IFFS modeling system, or in stand-alone mode. The projections from this module are published in the Energy Information Administration (EIA) publication Annual Eningy Outlook.

Energy System Described by Model: Domestic petroleum supply. refinery gate prices, and product end-use prices.

Coverage.

- Geographic: The solution for refinery gate prices by product category is found at the national level for the eight product categories. These prices are then marked to retail to account for regional and sectoral differences.

- Time Unit/Frequency: The short-run version of the model is calibrated to 1988. The long-run version of the model can be calibrated to any base year and run for any mix of crude price and product supplies within the ranges of the data set used to estimate the model. The model solves for an annual frequency.

- Product(s): Motor gasoiine, distiiiate futi oii, huigh sulfur residual fuel oil, low sulfur residual fuel oil, jet 
fuel, liquefied petroleum gases, petrochemical feedstocks, other petroleum products, and crude oil.

- Economic Sector(s): Oil Refinery Sector

\section{Modeling Features:}

- Model Structure: Simultaneous equations

- Modeling Technique: Econometric modeling of pseudo data

- Special Features: Refinery gate price estimates based upon translog approximation of the Oil Trade Model (OTM)

Non-DOE Input Sources: None.

DOE Data Input Sources:

Forms and Publications:

- Energy Information Administration, Petroleum Supply Annual, DOE/EIA-0340, (Washington, DC)

- Net imports

- NGL allocation to products

- Gross exports

- Refinery gain

- Unaccounted for crude

- Crude oil supplied directly

- Ether blended into gasoline

- Other hydrocarbons blended into gasoline

- Fraction of unfinished oils

- Motor gasoline blending compounds fraction

- Stock withdrawals

- Energy Information Administration, Petroleum Marketing Annual, DOE/EIA-()487, (Washington, DC)

- Data used to derive end-use markups

Models and Other:

- Energy Information Administration, Intermediate Future Forecasting System (IFFS)--MAIN module, and supply and demand models

- End-use petroleum products demand
- Crude oil production

- Natural gas production

- Fill rate of Strategic Petroleum Reserve.

\section{General Output Descriptions:}

- Petroleum product end-use prices for eight product categories by region and sector

- Petroleum product imports for eight product categories

- Domestic refinery gain and crude runs.

Computing Environment:

- Hardware Used: IBM 3090-400E, 3084QX

- Operating System: OS or OS/VS

- Language/Software Used: FORTRAN 77 (primary source code) and SAS (used offline to estimate econometric parameters)

- Memory Requirement: $5000 \mathrm{~Kb}$

- Storage Requirement: 3380 disk -- Fewer than 1400 tracks

- Estimated Run Time: When OMM is the only active module (of IFFS) executing, it requires 60 seconds to solve from 1995 through 2010

- Special Features: None.

Independent Reviews Conducted: Independent Expert Review conducted by T. Considine and A. Manne, October 1990.

Status of Evaluation Efforts by Sponsor: None.

\section{Oil Market Simulation Model (OMS-PC)}

Description: OMS-PC projects future world oil prices and world oil supplies and demands by region (the United States, Canada, Japan, Organization for Economic Cooperation and Development, OECD-Europe, Organization of Petroleum Exporting Countries, OPEC, developing countries, and net Communist trade) on an annual basis through the year 2010. The OMS-PC model is used as an adjunct to the World Energy Projection System (WEPSPC).

Last Model Update: August 1991.

Part of Another Model? No. 
Model Interfaces: None directly. Inputs from STIFS and IFFS.

\section{Sponsor:}

- Office: Office of Integrated Analysis and Forecasting

- Division: Energy Demand and Integration Division

- Branch: International, Economic and Integrated Forecasting Branch, EI-812

- Model Contact: Dan Butler

- Telephone: 202-586-9503

Documentation:

- Energy Information Administration, Oil Market Simulation Model Documentation Repon, DOE/EI/19656-2, (Washington, DC, May 1985).

- Energy Information Administration, Oil Market Simulation Model User's Guide, DOE/EIA-M028(92) (Washington, DC, July 1992).

Archive Media and Installation Manual(s):

- OMS81 - Annual Report to Congress 1981

- OMS82 - Annual Repont to Congress 1982

- OMS85 - Intemational Energy Outlook 1985

- OMS86 - Intemational Energy Outlook 1986

- OMS87 - Intemational Energy Outlook 1987

- OMS89 - Intemational Energy Outlook 1989

- OMS90 - Intemational Energy Outlook 1990 and the Annual Energy Outlook 1990

- OMS91 - Intemational Energy Outlook 1991 and the Annual Energy Outlook 1991

- OMS92 - Intemational Energy Outlook 1992 and the Annual Energy Outlook 1992

- OMS93 - Intemational Energy Outlook 1993 and the Annual Energy Outlook 1993.

Purpose: The model forecasts annual world oil prices and regional supplies and demands through the year 2010 . The model consists of regional oil supply and demand equations with oil supply a composite of conventional sources and oil demand determined as a function of both prices and income. The model can be used to simulate OPEC production, given a projection of world crude oil prices, or to estimate oil prices for any given level of OPEC production capacity.

Energy System Described by Model: The model describes world oil supply and demand on a regional basis annually from the present through the year 2010.

\section{Coverage:}

- Geographic: U.S., Canada, Japan, OECD-Europe, OPEC, and developing countries

- Time Unit/Frequency: From the present through the year 2010, annually

- Product(s): Crude oil and natural gas liquids

- Economic Sector(s): All oil consuming countries, regionalized as above.

Modeling Features:

- Model Structure: Dynamic, recursive

- Modeling Technique: Parametric representation of embodied aggregate supply and demand elasticities

- Special Features: Operational, both in interactive and batch mode.

Non-DOE Input Sources:

- Cambridge Energy Research Associates, The Capacity Race--The Future of World Oil Supply

- Reference price--international

- Central Intelligence Office of Economic Research, Intemational Energy Statistical Review

- OPEC production capacity--through 1980.

DOE Data Input Sources:

Forms and Publications:

- Energy Information Administration, Annual Energy Outlook, DOE/EIA-0383 (Washington, DC)

- U.S. supply/demand projections

- Energy Information Administration, Shon-Term Energy Outlook, DOE/EIA-0202 (Washington, DC)

- U.S. supplyidemand projections

- Energy Information Administration, Intemational Petroleum Statistics, DOE/EIA-0520 (Washington, DC)

- Historical consumption - international 
- Historical production - international

- Data used to estimate price elasticities, income elasticities, feedback elasticities and lags

- Energy Information Administration, Intemational Energy Annual, DOE/EIA-0219 (Washington, DC)

- Historical consumption - international

- Historical production - international

- Data used to estimate price elasticities, income elasticities, feedback elasticities and lags

- Energy Information Administration, Monthly Energy Review, DOE/EIA-0035, (Washington, DC)

- World oil prices

- U.S. historical supply/demand

- Energy Information Administration, Annual Energy Review, DOE/EIA-0384

- World oil price

- U.S. historical supply/demand

- Office of International Affairs, Intemational Energy Indicators, DOE/IA/0010/6, December 1980, (Washington, DC)

- OPEC production capacity--through 1980

Models and Other:

- Internal estimates from International, Economic and Integrated Forecasting Branch, EI-812

- OPEC production capacity--1981 forward.

General Output Descriptions: OMS-PC model users can specify the world oil price path over time. The model accepts the user-specified prices to compute the world regional demand and supply. Output of this includes OPEC production, free world production, free world consumption, net U.S. imports, OPEC revenues, and excess OPEC capacity. The OPEC price reaction function can be used to evaluate oil prices. OMS-PC model users specify the demand and supply path over time. The model accepts these to compute world price levels. Output is similar to that of a production run, except that price is included as well. An OMS-PC model user can also specify an OPEC output (production) path, and the model will search for a world oil price such that the model solution will converge to the user-specified quantity or levels. Output of this run is similar to that of a price run. In a disruption run, OMSPC model users can specify a reduction in OPEC capacity to trigger the disruption algorithm, and the model will be solved for world oil price, world oil demand, and world oil supply.

\section{Computing Environment:}

- Hardware Used: IBM-compatible personal computer

- Operating System: MS DOS

- Language/Software Used: Lotus 1-2-3, Version 2

- Memory Requirement: 1.2 Mb to load Lotus 1-2-3 and retrieve the OMS model (the largest file on the OMS diskette), $200 \mathrm{~Kb}$ to use the DEMO diskette

- Storage Requirement: $300 \mathrm{~Kb}$

- Estimated Run Time: On a Compaq 386, 10 seconds

- Special Features: Fast turnaround.

Independent Reviews Conducted:

- Oil Market Simulation Model Documentation Review Report, John Kraft, Independent Expert Review, October 13,1980

- Oil Market Simulation Model Documentation Repont, William Gaynor, Independent Expert Review, February 15,1983

- Oil Market Simulation Model Documentation Repon, Williain M. Fitzgerald, Independent Expert Review, November 25,1983

- An Evaluation of the Oil Market Simulation Model, Dennis Epple, Independent Expert Review, April 1986.

- Intemational Oil Supply and Demand, Energy Modeling Forum, Stanford University, Palo Alto, CA, September 1991.

Status of Evaluation Efforts by Sponsor: None.

\section{Petroleum Financial Analysis System (PETFAS-PC)}

Description: PETFAS-PC is designed to utilize Annual Energy Outlook (AEO) model results for oil and gas prices, domestic drilling levels and drilling cost relationships. It also uses information from the $A E O$ on oil and gas reserves and production to provide forecasts of investment and profits for the U.S. oil and gas production industry. Detailed income statement, capital account, balance sheet, and tax information is provided for two main industry categories--major energy companies' domestic oil and gas seginents and domestic independent producers.

Last Model Update: February 1988. 
Part of Another Model? Designed not as a principal model involved in iterative solution algorithm for PC-AEO, but as a post-solution report writer with some embedded behavioral characteristics relating to industry structure. Can operate in stand-alone mode with internal oil and gas supply equations or with Annual Energy Outlook inputs supplemented by user options.

Model Interfaces: In Annual Energy Outlook mode, uses inputs directly from the oil and gas and macro modules solutions from PC-AEO to forecast investment and income for the oil and gas sector.

Sponsor:

- Office: Office of Energy Markets and End Use

- Division: Energy Markets and Contingency Information Division

- Branch: Financial Analysis Branch, EI-622

- Model Contact: Arthur Rypinski

- Telephone: $202-586-8425$

Documentation: Energy Information Administration, Model Documentation for the Petroleum Financial Analysis Personal Computer Model, (PETFAS), April 1988.

Archive Media and Installation Manual(s): Archived as part of PC-AEO.

Purpose: Make explicit the implications for financial health/performance of the domestic oil and gas industry embedded in PC-AEO and other energy model results.

Energy System Described by Model: Domestic oil and gas production industry.

Coverage:

- Geographic: National

- Time Unit/Frequency: Annual

- Product(s): None

- Economic Sector(s): U.S. oil and gas production sector, for total United States, majors and independents.

\section{Modeling Features:}

- Model Structure: Recursive model. Calculates aggregate financial results for aggregate industry using inputs on real activity levels and prices from PC.AEO or elsewhere as exogenous. Solves in top-down fashion for industry sector results.
- Modeling Technique: Key behavioral relationships estimated using ordinary least squares regressions on pooled time-series cross-section data base created from survey data at the corporate level.

- Special Features: Constructed in Lotus 1-2-3 with menu-driven structure to allow user to specify alternative input assumptions.

Non-DOE Input Sources: None.

DOE Data Input Sources:

Forms and Publications: None

Models and Other: Energy Information Administration, Personal Computer - Annual Energy Outlook (PC-AEO) Model

- Drilling/equipping expenditure

- Unit drilling and equipping cost

- Footage drilled

- Domestic reserves added

- Shares of total reserves added

- Domestic production

- Domestic reserves

- Real world oil price

- Real domestic wellhead gas price

- Corporate bond yield

- Wholesale price index

General Output Descriptions: Detailed output for both industry sectors on revenue and expenses (including windfall profits tax), operating income, interest expense, pretax income, sources of tax deferral, income tax calculations, investment in fixed assets, changes in long-term debt and stockholders' equity. Results make possible comparisons over time and between sectors of cash flow, changes in financial condition, and effective tax rates.

\section{Computing Environment:}

- Hardware Used: IBM-compatible personal computer

- Operating System: MS DOS, Version 3.2 or higher

- Language/Software Used: Lotus 1-2-3, Version 2.01 or higher

- Memory Requirement: $1 \mathrm{Mb}$ 
- Storage Requirement: $330 \mathrm{~K}$ of disk space

- Estimated Run Time: On a Compaq 386/16 operating under DOS 3.31 approximately 5 minutes

- Special Features: None.

Independent Reviews Conducted: None.

Status of Evaluation Efforts by Sponsor: None.

\section{Production of Onshore Lower 48 Oil and Gas Model (PROLOG)}

Description: PROLOG forecasts oil and natural gas production activities for six onshore regions of the lower $\mathbf{4 8}$ States on an annual basis. The prinary activities are exploratory and developmental drilling. Forecast values include the reserve additions from exploratory drilling, as well as production from all flowing wells. The PROLOG model employs econometric equations to determine exploratory drilling levels and a linear programming framework to determine the optimal developmental drilling levels that inaximize the present value of profits stemming from the drilling projects.

Last Model Update: January 1991

Part of Another Model? PROLOG is used as a stand-alone model and component of the Gas Analysis Modeling System (GAMS) and the Intermediate Future Forecasting System (IFFS).

Model Interfaces: Primary inputs to the PROLOG model are exogenously forecasted price paths for both oil and natural gas. World oil price paths for both oil and natural gas. World oil price projections are usually supplied by the EIA International and Contingency Information Division. In general, gas prices are obtained from output of the Gas Analysis Modeling System (GAMS), when PROLOG is run interaciively with the GAMS integrated solution, and only requires crude oil prices as an exogenous input. In return, PROLOG passes information on natural gas production capability for use in determining the equilibrium price and realized levels of production.

Sponsor:

- Office: Office of Integrated Analysis and Forecasting

- Division: Energy Supply and Conversion Division

- Branch: Oil and Gas Analysis Branch, EI-823

- Model Contact: Ted McCallister

- Telephone: $202-586-4820$

\section{Documentation:}

- Energy Information Admin stration, Model Methodology and Data Description of the Production of Onshore Lower 48 Oil and Gas Model, DOE/EIA-M034 (Washington, DC, September 1988)

- Energy Information Administration, Software Description and User's Guide for the Production of Onshore Lower 48 Oil and Gas Model, DOE/EIA-M020 (Washington, DC, June 1991).

Archive Media and Installation Manual(s):

- PROLOG82 - A nnual Energy Outlook 1982

- PROLOG83 - Annual Energy Outlook 1983

- PROLOG84 - Annual Energy Outlook 1984

- PROLOG85 - Annual Energy Outlook 1985

- PROLOG86 - Annual Energy Outlook 1986

- PROLOG88 - Annual Outlook for Oil and Gas 1988, the Annual Outlook for U.S. Electric Power 1988, and the Annual Outlook for U.S. Coal 1988

- PROLOG89 - Archived for the Annual Outlook forOil and Gas 1989, the Annual Outlook for U.S. Electric Power 1989, the A nnual Outlook forU.S. Coal 1989, and Electricity Generation from Natural Gas: Prospects and Implications for the United States

- PROLOG91-Archived for the Annual Energy Outlook 1991, the Annual Outlook for Oil and Gas 1991, the Annual Outlook for U.S. Electric Power 1991, and the Annual Outlook for U.S. Coal 1991.

Purpose: PROLOG is used by the Analysis and Forecasting Branch in the Office of Oil and Gas as an analytic aid to support preparation of medium term ( 10 to 20 years) projections of reserve and production of crude oil and natural gas at the regional and national level, so as to illustrate the potential effects of alternative policies, regulations, and economic environments on domestic gas production. The PROLOG model is regularly run in conjunction with the Gas Analysis Modeling System (GAMS) (see Model Documentation of the Gas Analysis Modeling Syrtem (DOE/EIA-0450)). These annual projections and associated analyses have appeared in the EIA publications Annual Energy Outlook and Annual Outlook for Oil and Gas. Most recently the model has been used to provide oil and gas production forecasts for the Annual Energy Outlook 1991 and the Annual Outlook for Oil and Gas 1991. The projections are also provided as a service to other branches of the U.S. Department of Energy, the Federal Government, and non-Federal public and private institutions concerned with the domestic natural gas industry. 
Energy System Described by Model: The PROLOG model forecasts oil and natural gas production activities for six onshore regions of the lower 48 Siates on an annual basis. The primary activities are exr loratory and developmental drilling. Forecast values include the reserve additions from exploratory drilling as well as production from all flowing wells. Drilling activities are differentiated by category. Oil and natural gas drilling are evaluated separately for each subclass of drilling. Exploratory and developmental drilling are treated separately, with developmental drilling further subdivided by the type of reserves to be developed. Exploration yields new additions to the stock of known reserves. Development determines the rate of production from the stock of known reserves.

\section{Coverage:}

- Geographic: Onshore, lower 48 States

- Time Unit/Frequency: Annual, 1985 through 2010

- Product(s): Oil and natural gas production

- Economic Sector(s): None.

Modeling Features:

- Model Structure: The model employs a linear programming framework to determine the optimal developmental drilling levels that maximize the expected present value profits stemming from the drilling projects.

- Modeling Technique: The primary activities are exploratory and developmental drilling. Oil and natural gas drilling are evaluated separately for each subclass of drilling. All drilling activities, with the exception of exploratory drilling, are evaluated by calculating the discounted cash flow (DCF) to measure the expected present value profits for the proposed effort. The current model contains econometrically estimated equations for exploratory drilling for oil and shallow and deep natural gas.

- Special Features: PROLOG explicitly represents various segments of the supply side of the oil and gas markets. This detailed representation significantlyenhances the analytic capabilities of the Energy Information Administration for use in determining the equilibrium price and realized levels of production.

\section{Non-DOE Input Sources:}

- Internal Revenue Service (IRS) Regulations

- Federal tax rate

- Commerce Clearing House Inc., State Tax Guide, Statute Summaries, by Taxes, by State, 1987
- State corporate income tax rates

- State severance (production) taxes

- Colorado School of Mines, Oil Property Evaluation, 1983

- State ad valorem taxes

- State severance (production) taxes

- Colorado School of Mines, Potential Gas Committee, Potential Supply of Natural Gas in the United States, (as of December 31, 1978)

- Undiscovered recoverable gas data used to derive finding rate parameters for natural gas (by depth)

- American Petroleum Institute (API) well records (computer tapes), 1970-1990

- Average well depths

- Developments drilling footage for calibration

- 1970-1989 data used to obtain parameters for exploratory well completion equations

- Drilling footage data used to estimate initial finding and revisions rates

- Developmental drilling ratios

- 1970-1988 data used to estimate elasticity of average drilling cost per foot with respect to total footage drilled

- Success rates for developmental and exploratory oil and gas drilling

- American Petroleum Institute (API)/American Association of Petroleum Geologists (AAPG) Well Data System

- Deep gas data (exploratory success ratio, developmental-to-exploratory footage ratio, exploratory average well depth)

- American Petroleum Institute, Independent Petroleum Association of American, and Mid-Continent Oil and Gas Association, 1988 Joint A ssociation Survey on Drilling Costs, September 1990

- Drilling cost and well-depth data used to obtain constant and slope parameters for drilling cost curves, to estimate elasticity of average drilling cost per foot with respect to total footage drilled, and to derive coefficients for linear program constraint equations 
- Hughes Tool Company, Rotary Rigs Running -- By State

- Number of rotary rigs running

- Hughes Tool Company, Hughes Rotary Rig Census, 1985

- Average number of rotary drilling rigs in service in 1985

- Dwight's Energydata

- Average first year production per well

- U.S. Geological Survey, Minerals Management Service, Estimates of Undiscovered Conventional Oil and Gas Resources in the United States--A Part of the Nation's Energy Endowment, 1989

- Undiscovered recoverable oil and gas data used to derive finding rate parameters for oil and shallow gas

- Inferred reserves in 1989

- U.S. Geological Survey, Open-File Report 81-192, 1981

- Undiscovered recoverable gas data used to derive finding rate parameters for deep gas

- Reed Tool Company, Reed Rig Census (Annual)

- Available rigs used to obtain parameters in rig stock equation.

\section{DOE Data Input Sources:}

\section{Forms and Publications:}

- Energy Information Administration, U.S. Crude Oil, Natural Gas, and Natural Gas Liquids Reserves, DOE/EIA-0216, (Washington DC, 1980 - 1990 Annual Reports)

- 1985 reserves and production

- Oil (including lease condensate) production and reserves for benchmarking

- Coproduct ratios

- Reserve additions data used to estimate initial finding and revisions rates

- Historical end-of-year reserves and production

- Energy Information Administration, Natural Gas Annual, DOE/EIA-0131, (Washington, DC)
- 1987 shares for onshore gas production and beginning-of-year reserves for benchmarking

- Historical gas production

- Energy Information Administration, Natural Gas Monthly, (Washington, DC, May, 1990)

- 1970-1989 fuel prices used to obtain parameters for exploratory well completion equations

- Energy Information Administration Petroleum Supply Annual, Volume I, DOE/EIA-0340 (89)/1, (Washington, DC, May 1990)

- 1989 crude oil (including lease condensate) production by State

- Energy Information Administration, Drilling and Production Under Title I of the Natural Gas Policy Act 1978-1986, DOE/EIA0448(86), (Washington, DC, January 1989)

- Parameters for gas produced from enhanced gas recovery techniques

- 1981-1986 data on wells drilled, used to estimate coefficients for well completion equation

- Energy Information Administration, Annual Energy Review, DOE/EIA-0384, (Washington, DC, 1987-1989)

- Price for gas produced from enhanced gas recovery techniques

- 1970-1989 fuel prices used to obtain parameters for exploratory well completion equations

- Average drilling cost data series for oil and gas well drilling used to derive coefficients for linear program constraint equations

- 1981-1986 price data used to estimate coefficients for well completion equation

- Energy Information Administration, The Domestic Oil and Gas Recoverable Resene Base: Supponing Analysis for the National Energy Strat?:gy, SR/NES/90-05, (Washington, DC, December 1990)

- Undiscovered recoverable oil and gas data used to derive finding rate parameters for oil and shallow gas

- Undiscovered economically recoverable gas data used to derive finding rate parameters for unconventional gas

- Coal seams resource base level 
- Inferred reserves in 1989

- Energy Information Administration, Costs and Indexes forDomestic Oil and Gas Field Equipment and Production Operations, DOE/EIA-0815, (Washington, DC, 1981-1989)

- Data used to estimate lease equipment costs

- Data used to estimate operating costs

- Federal Energy Regulatory Commission, FERC Form 121, "Application for Determination of the Maximum Lawful Price Under the Natural Gas Policy Act of 1978"

- Average first year production per well

\section{Models and Other:}

- Energy Information Administration, Well Completion Estimation Model (WELCOM)

- Adjustments to American Petroleum Institute (API) data:

- Average well depths

- 1986-1991 developmental drilling footage for calibration

- 1970-1991 data used to obtain parameters for exploratory well completion equations

- 1970-1990 well depth data used with JAS drilling cost data to estimate elasticity of average drilling cost per foot with respect to total footage drilled

- Drilling footage data used to estimate initial revisions rate

- Title I Data base

- 1987 shares for onshore gas production and beginning-of-year reserves for benchmarking

- Derived parameters for gas from Devonian shale and tight sands formations (national average well depth, production-to-reserves (P/R) ratios, and footage and reserve additions shares)

- Drilling footage and reserve additions data used to derive initial and minimum economical finding rates for unconventional gas

- Historical end-of-year reserves and production for unconventional gas.

General Output Descriptions: The following reports are produced by the PROLOG model by year and region:
- Oil exploratory drilling

- Oil developmental drilling--old fields

- Oil developmental drilling--new fields

- Oil developmental drilling

- Total oil drilling

- Oil reserve additions

- Oil production--exploratory fields

- Oil production--old fields

- Oil production--new fields

- Oil production--total conventional

- Natural gas liquids production

- Liquid hydrocarbon production

- Exploratorydrilling

- Total gas exploratory drilling

- Reserves added

- Deep gas reserves added

- Enhanced gas recovery reserves added.

Computing Environment:

- Hardware Used: IBM $3090-400$ E, 3084 or $360 / 370$ (or equivalent)

- Operating System: MVS/XA or OS or OS/VS

- Language/Software Used: FORTRAN (VS compiler, Level 1.4.1, May 1985) and XMP (a specially designed proprietary linear programming package, callable from FORTRAN, developed by Roy E. Marsten)

- Memory Requirement: Less than $3000 \mathrm{K.b}$

- Storage Kequirement: 3350 permanent disk -- 11 tracks

- Estimated Run Time: PROLOG uses a proprietary software package XMP. This is a specially designed linear programming package that is callable from FORTRAN.

- Special Features: None.

Independent Reviews Conducted: 
- Charles River Associates, A ssessment of Natural Gas Market Models, April 1984

- Production of Onshore Lower 48 Oil and Gas Model, presentation by William Trapmann to the International Association for Mathematics and Computers in Simulation Conference, held at the Brookhaven National Laboratory, Upton, NY, August 1984.

- An Analysis of Forecast Uncertainty, presentation by William Trapmann to the Operations Research Society of America/The Institute of Management Sciences, November 1985.

Status of Evaluation Efforts by Sponsor: None.

\section{Refinery Evaluation Modeling System (REMS)}

Description: REMS consists of two models. The Regional Refinery Yield Model (RYM) produces a detailed representation of refinery processes and product production. The Oil Refining and Distribution Model (ORAD) simulates the industry's interregional producing, refining, and distribution network throughout the United States. RYM can run over 130 different foreign and domestic crude types, which are represented as linear combinations of 37 principal crudes, as defined by their assays. RYM refineries produce over 35 petroleum products using 21 detailed refinery process units. ORAD represents an aggregated bundle of domestic and foreign crudes available from the RYM, an aggregated bundle of petroleum products, and transportation modes and links for crude oil and petroleum products among regions.

Last Model Update: October 1986.

Part of Another Model? No.

Model Interfaces: REMS is a domestic model, and, as such, it requires certain assumptions. REMS requires data on the costs and availability of different crudes available both domestically and in the world market. A basis for determining these costs and quantities can be obtained by running the Oil Market Simulation (OMS) model in conjunction with the Intermediate Future Forecasting System (IFFS) (if the period under study is a full year) or the Short-Term Integrated Forecasting System (STIFS) (if the focus is on seasons, quarters, or months). REMS also requires initial entries for petroleum products demand and prices, because, as currently configured, REMS is not an equilibrating model for supply and demand. Either STIFS or IFFS must supply these. REMS can also be used to calibrate the refinery representations within the IFFS and STIFS. REMS refinery operating vectors can be used to update the refinery yields relating to the running of various crudes available both domestically and from foreign sources.
Sponsor:

- Office: Office of Integrated Analysis and Forecasting

- Division: Energy Supply and Conversion Division

- Branch: Oil and Gas Analysis Branch, EI-823

- Model Contact: Gerald Harp

- Telephone: 202-586-7591

Documentation:

- Refinery Evaluation Modeling System (REMS) Model Documentation, (released in July 1984 and available through the model contact)

- Energy Information Administration, Refinery Evaluation Modeling System (REMS) Database Documentation, DOE/EIA-M011, (Washington, DC, August 1985).

Archive Media and Installation Manual(s):

- REMS83 - for the report Refinery Evaluation Modeling System 1983 Validation Results

- REMS86 - for the report Refinery Evaluation Modeling System 1986 Validation Results.

Purpose: REMS simulates the operations of refineries within the United States, including the purchases and transportation of crude oils and other raw materials to refineries, the processing of these raw materials into petroleum products, and the distribution of petroleum products to meet regional demands. The model chooses the set of these petroleum industry activities which maximizes the gross margin at the refinery level within the industry. Gross margin is defined as the difference between product revenues and the sum of the cost of crude oil and raw materials, refineryoperations, and the transportation of raw materials to refineries and products to market. REMS determines the potential impact on refinery operations of changes in any one or combination of several variables, including demands for petroleum product slates, crude and feedstock quality, costs and prices, refinery process unit capacities, foreign and domestic crude availability and costs, petroleum transportation mode availability, capacity, and Government energy policies and regulations. REMS can also be used to assist short-term and longer term integrating energy models (e.g. the Short-Term Integrated Forecasting System and the Intermediate Future Forecasting System of E1A) in the preparation of forecasts. This can be accomplished by driving REMS with prices and volumes of product demands and available crudes taken from these models and then executing REMS to determine optimal refinery processing and petroleum distribution patterns. REMS can also be used to update and calibrate the simpler refinery representations within these models. 
Energy System Described by Model: REMS includes a regional representation for crude producing activities, natural gas plant operations, transportation modes for raw materials and petroleum products (pipelines, water vessels, and trucks/railroads), refinery distillation and downstream processes, and petroleum product demands. REMS consists of two components: regional Refinery Yield Model (RYM), and the Oil Refining and Distribution Model (ORAD). RYM contains a detailed representation of refinery processes and product production. The refineries can run over 130 different foreign and domestic crude types, which are represented as a linear combination of about 37 principal crudes, as defined by their assays. RYMs refineries produce over 35 petroleum products using 21 separate, detailed refinery process units. ORAD simulates the industry's interregional producing, refining, and distribution network throughout the United States. It represents an aggregated bundle of domestic and foreign crudes available to the RYM (one domestic crude from each producing region and approximately 22 foreign crudes), as an array of 22 petroleum products, and transportation modes and links for crude oil and petroleum products among regions.

\section{Coverage:}

- Geographic: Five regions based Petroleum Administration for Defense Districts (PAD Districts), plus separate districts for refineries in Puerto Rico and the Virgin Islands, other non-U.S. Caribbean refineries, foreign producers of crude, and two Strategic Petroleum Reserve producing sites.

- Time Unit/Frequency: The 1985 data base contains annual data. However, because the units used within the model are in terms of rates (thousand barrels per day is the most prevalent), the static version of the model can be exercised over any single period of time. The data base, of course, would have to be revised.

- Product(s): RYM represents the running of over 130 different crude types in refineries, and the production of over 35 different refinery products using 21 separate, detailed refinery processes. In the ORAD module, refineries consume 9 domestic and 22 foreign crudes, and produce 22 petroleum products.

- Economic Sector(s): None.

\section{Modeling Features:}

- Model Structure: REMS is a static, linear programming model which obtains an optimal solution using a two-step process. REMS is divided into a regional RYM module and the ORAD module. Each are static linear programming modules containing three basic programs--a preprocessor and matrix generator, a program which calls MPS-III to solve the linear programming problem, and a report writer. There is a regional RYM for each refinery district within the model. The same OMNI programming code is used to run each RYM. However, each of the regions bas slightly different refinery process unit configurations, thereby better representing differences in actual regional refinery capabilities. One ORAD module simulates the entire industry interregional producing, refining, and distribution network within the United States. REMS is not a price equilibrium model as it is now constructed. The model can be used to allocate shortfalls to demand regions, given the availability of crudes and prices and the prices and quantities of products demanded. The model can be used to reach an equilibrium supply-demand solution if the increments of crude supplies and petroleum products demand are priced at levels approximating step-function supply and demand curves, respectively. A noteworthy feature of REMS is that it is data-driven. Major changes in the level of aggregation of crudes, refinery processes, petroleum products, etc., can be simulated with no changes to the programming code, simply by altering data input tables.

- Modeling Technique: Static linear programming model.

- Special Features: An important feature of REMS is that it produces major petroleum products (motor gasolines, jet fueis, kerosene, and fuel oils) to specification. This feature allows an excellent representation of the flexibility in processing actually available to refiners. Input tables within the RYM define specifications such as volatility, octane rating, Reid vapor pressure, and distillation cut points. Nonlinearities in blending are taken into account byproviding "bonuses" in specifications for certain blends. The RYM then produces products to equal or exceed the minimum required specifications. Other products are blended to recipe. Another special feature is the two-step optimization process obtained through the use of the RYMORAD combination of linear programming. This two-step optimization is based on the Theory of Decomposition of linear programming solutions. Simply stated, RYM defines extreme points of a surface of optimal and feasible solutions which maximize gross margins for refiners within a single region, ORAD determines the specific solution as a linear combination of these extreme points, after taking into account the interregional economics involved. This two-step process allows for greater efficiency in running REMS because the time-consuming RYM does not have to be rerun for each scenario unless the optimal surface defined by the RYM is expected to be exceeded.

\section{Non-DOE Input Sources:}

- Platt's Oilgram, January 2, 1985

- Revenues per unit or prices at refinery gate

- Fixed or equivalency production 
- Platt's Oil Price Handbook, 60th Edition, 1983

- Raw Material unit costs -- domestic and foreign crude

- Platt's Oilgram Price Report

- Raw material unit costs--foreign crude

- Shell Oil Company (information from former employees)

- Raw material unit costs -- foreign crude

- Chevron Oil Company, Crude Oil Price Bulletins, 1983

- Raw material unit costs -- foreign crude

- "Value of Oxygenates in Blending, Octane Improvements for MOGAS Appraised," Oil and Gas Joumal, (June 1, 1981)

- Data used to estimate unit cost of tetracthyl lead

- "Annual Refining Survey," Oil and Gas Joumal, (March 18, 1985)

- Refinery unit capacities (capacity of refinery processing units, capacity utilization bounds, stream day factor and number of refineries per region)

- "Guide to World Export Crudes," Oil and Gas Joumal, (1983)

- Crudes represented by assayed crudes

- Aunospheric and vacuum crude unit (intermediate streans; capacity factor; fuel (natural gas), electricity and steam consumption; variable costs; vacuum Uistillation capacity consumption; fixed refinery losses coefficient; and coefficient for adjustment to plant fuel) -- selected crudes

- "Coking Process Reflects Trends," Oil and Gas Joumal, (April 19, 1983)

- Delayed coker (refinery intermediate process strcams; capacity factor; purchased fuel (natural gas), electricity and steam consumption; and variable operating cost)--clarified oil processing activity

- Oil and Gas Joumal, (November 1, 1982 and August 7, 1978)

- Nelson indices for investment, maintenance, etc.; delayed coker; fluid coker; visbreaker and thermal cracker; fluid catalytic cracker; feed hydrofiner; vacuum residual desulfurization; reformer; semiregeneration $450 \mathrm{PSI}$ and semi regeneration/cycle
200 PSI reactors; fluid catalytic cracker; FCC gasoline fractionation; hydrocracker; alkylation unit; aromatics recovery plant; lube and wax production units; pentane/hexane unit; butane isomerization unit; hydrogen manufacturing plant; boiler steam production

- Dual Gasification Coking Process Option for Synthetic Gas Production," Oil and Gas Joumal, (May 17, 1982)

- Fluid coker (refinery intermediate process streams generated and consumed; fuel (natural gas), electricity and steam consumption; variable operating costs; and capacity factors)--flexicoking operations

- "Europe Holds Key Role for Thermal Cracking," Oil and Gas Joumal, (November 1981)

- Visbreaker and thermal cracker: Input and produced refinery intermediate process streams--additional activity

- $\quad$ "Residual HDS Gets Low Rating in Europe," Oil and Gas Joumal, (September 7, 1981)

- Vacuum residual desulfurization: input and produced refinery intennediate process streams--additional activity

- New Resid HDS Process Has Long Run,"Oil and Gas Joumal, (May 28, 1979)

- Vacuum residual desulfurization: input and produced refinery intermediate process streams--additional activity

- "Technology Improves for Processing Sour Residual," Oil and Gas Joumal, (August 19, 1974)

- Vacuum residual desulfurization: input and produced refinery intermediate process streams--additional activity

- Oil and Gas Joumal, (December 21, 1981)

- Fluid catalytic cracker: input and produced refinery intermediate process streams--additional activities

- "Shell Singapore, Part of Hydrocracking Wave," Oil and Gas Joumal, (December 14, 1981)

- Hydrocracker: input and produced refinery intermediate process streams--additional activities

- "BP Hydrocracks for Middle Distillates," Oil and Gas Joumal, July 8, 1976 
- Hydrocracker: input and produced refinery intermediate process streams--additional activities

- 'H ydrocracking's Role in Resid Schemes," Oil and Gas Joumal, (November 2, 1981)

- Hydrocracker: input and produced refinery intermediate process streams--additional activity

- Changes Keep HF Alkylation Up to Date," Oil and Gas Joumal, February 11, 1974.

- Alkylation unit (input and produced refinery in . termediate process streams; capacity factor; purcliased natural gas, elcatricity and steam consumption; and variable operating costs)

- $\quad$ Hysoner May Ease Lead Elimination," Oil and Gas Joumal March 8, 1981

- Pentane/hexane isomerization unit: purchased natural gas, electricity and stean consumption

- $\quad$ "Penex Unit Peps Up SR Gasoline," Oil and Gas Journal, (October 26, 1970)

- Pentane/hexane isomerization unit: purchased natural gas, electricity and stean consumption

- Oil and Gas Joumal, (July 15, 1985)

- Gas plant capacity constraints

- Original Turner, Masion and Associates (TMA) model

- Gasoline component usage control

- Distillate and fuel oil specifications: unit cost of blending, electricity consumption, steam consumption, API gravity, sulfur content (high sulfur), luminometer reading, flash index, Reid vapor pressure and volatility

- Dist. llate/fuel oil component usage control

- Recipe products contror (unit cost of blending, tetraethyl lead, stean requirements and recipe proportions)--aviation gasoline and special naphthas, and asphalt

- Report headings and other lines

- Crudes represented by assayed crudes

- Gasoline component octane ratings

- Gasoline component bonuses

- Gasoline component volatility blending values
- Distillate/fuel oil blending values

- Piping network and miscellaneous transfers (transfer rates and unit costs of transfers)

- Scale factors for some rows of unit tables

- Aumospheric and vacuum crude unit (intermediate streams; factor, fuel (natural gas), electricity and steam consumption; variable costs; vacuum distillation capacity consumption; fixed refinery losses coefficient; and coefficient for adjustment to plant fuel)

- Delayed coker (refinery intermediate process streams; capacity factor; purchased fuel (natural gas), electricity and steam consumption; and variable operating costs)--low and high sulfur residual fuel oil activities

- Fluid coker (refinery intermediate process slieams generated and consumed; fuel (natural gas), electricity and steam consumption; variable operating costs; and capacity factors)--fluid coking operations

- Visbreaker and thermal cracker (input and produced refinery intermediate process streams; capacity factor; purchased natural gas, electricity and steam consumption; and variable operating costs)

- Naphtha cat hydrotreater (input and produced refinery intermediate process streans; capacity factor; purchased natural gas, electricity and steam consumption; and variable operating costs)

- Distillate hydrodesulfurizer (input and produced refinery internediate process streams; capacity factor; purchased natural gas, electricity and steam consumption; and variable operating costs)

- Fluid catalytic cracker feed hydrofiner (input and produced refinery internediate process streams; capacity factor; purchased natural gas, electricity and steam consumption; and variable operating costs)

- Vacuum residual desulfurization (input and produced refinery internediate process streams; capacity factor; purchased natural gas, electricity and steam consumption; and variable operating costs)

- Reformer: semiregeneration 450 PSI and semiregeneration/cycle 200 PSI reactors (input and produced refinery intermediate process streams; capacity factor; purchased natural gas, electricity and steam consumption; variable operating costs; severity; and maximum severity) 
- Fluid catalytic cracker (input and produced refinery intermediate process streams; capacity factor; purchased natural gas; electricity and steam consumption; and variable operating costs)

- FCC gasoline fractionation (input and produced refinery intermediate process streams; capacity factor; purchased natural gas, electricity and steam consumption; and variable operating costs)

- Hydrocracker (input and produced refinery intermediate process streams; capacity factor; purci.nced natural gas; electricity and steam consumption; variable operating cos's; sulfur plant feed coefficient; and severity of hydrocracker operating mode)

- Aromatics recovery plant (input and produced refinery intermediate process streams; capacity factor; purchased natural gas; electricity and steam consumption; and variable operating costs)

- Lube and wax production units (input and produced refinery inturnediate process streams; capacity factor; purchased natural gas, electricity and steam consumption; and variable operating costs)

- Pentane/hexane isomerization unit (input and produced refinery intermediate process streams; capacity factor; purchased natural gas, electricity and steam consumption; and variable of,arating costs)

- Butane isomerization unit (input and produced refinery intermediate process streams; capacity

- factor; purchased natural gas; electricity and steam consumption; and variable operating costs)

- Hydrogen manufacturing plant (input and produced refinery internediate proccss streams; capacity factor; purchased natural gas, electricity and steam consumption; and variable operating costs)

- Sulfur production and hydrogen sulfide recovery (input and produced refinery internediate process streams; capacity factor; purchased natural gas, electricity and steam consumption; variable operating costs; sulfur; and sulfur plant feed coefficient)

- Stocks to fuel mixings (iriput and produced refinery intermediate process streams; capacity factor, and purchased natural gas consumption)

- Power generation (input steam consumption, power generated and capacity factor)
- Boiler steam production (inpist natural gas, steam production, capacity factor, electricity and variable operating costs)

- Produced fuel adjustment (process gas feed fraction; propane, normal butane and isobutane yield; losses; capacity factor; and adjustment to produced fuel)

- Special blending combinations

- Generation of movement constraints

- Types of pipelines

- Constraints on joint movements from/to locations-interregional water movement constraints

- Types of water transport

- Days of water transportation use

- Roundtrip days for water movements

- Types of rail and truck transportation

- Rail and truck transportation costs

- Free rows to accumulate costs (raw material costs, distribution costs of raw materials, distribution costs of products, operating costs of refineries, operating costs of gas plants and working inventory costs)

- Sobotka and Company, Inc. (SCI) Changes to the original TMA model

- Distillate/fuel oil component usage control--intermediate sulfur components

- Recipe products control (unit cost of blending, tetraethyl leadsteam requirements and recipe proportions)--petrochemical naphtha and gas oil

- Crudes represented by assayed crudes--selected areas

- Gasoline component octane matings--new components

- Gasoline component volatility blending values-new components

- Distillate/fuel oil blending values--new mid-quality components

- Piping network and miscellaneous transfers (transfer rates and unit costs of transfers)--additional components 
- Atmospheric and vacuum crude unit (intermediate streams; capacity factor; fuel (natural gas), electricity and steam consumption; variable costs; vacuum distillation capacity consumption; fixed refinery losses coefficient; and coefficient for adjustment to plant fuel)--selected crudes

- Polymerization plant (refinery intennediate process streams, losses, capacity factor for the process plant, steam consumption, electricity consumption and variable costs)

- Delayed coker (refinery intermediate process streams; capacity factor; purchased fuel (natural gas), electricity and steam consumption; and variable operating costs)--clarified oil processing activity

- Fluid coker (refinery intermediate process streams generated and consumed; fuel (natural gas), electricity and steam variable operating costs; and capacity factors)--flexicoking (pperations

- Vacuum residual desulfurization: input and produced refinery internediate process streams--additional activity

- Reformer: semi-regeneration 450 PSI and a semiregeneration/cycle 200 PSI reactors: adjustments to input and produced refiner intermediate process streams

- Fluid catalytic cracker: adjustments to purchased natural gas, electricity and steam consumption

- FCC gasoline fractionation: revisions to input and produced refinery internediate process streams

- Hydrocracker: input and produced refinery intermediate process streams--additional activities

- Alkylation unit (input and produced refinery intennediate process streams; capacity factor; purchased natural gas, electricity and steam consumption; and variable operating costs)

- Aromatics recovery plant: input and produced refinery intermediate process streans

- Butane isomerization unit: input and produced refinery intermediate process streams; capacity factor; and purchased natural gas, electricity and steam consumption

- Sulfur production and hydrogen sulfide recovery: input and produced refinery intennediate process streams--additional activity

- Boiler steam production: input natural gas
- Produced fuel adjustment: adjustment to produced fuel

- Oil Refinery and Distribution (ORAD) material name and type

- Raw material purchases: crude and gas liquids volumes and prices at second increment

- Constraints on joint movements from/to locations: interregional water movement constraints

- Executive Resource Associates, Crude Assay Data System, October 1979

- Crudes represented by assayed crudes

- Aunospheric and vacuum crude unit (intermediate streams; capacity factor; fuel (natural gas), electricity and steam consumption; variable costs; vacuum distillation capacity consumption; fixed refinery losses coefficient; and coefficient for adjustunent to plant fuel)--selected crudes

- Hydrocarbon Processing, Refinery Handbook, September 1982

- Delayed coker (refinery intermediate process streams; capacity factor; purchased fuel (natural gas), electricity and steam consumption; and variable operating costs)--clarified oil processing activity

- Fluid coker (refinery intermediate process streams generated and consumed; fuel (natural gas), electricity and steam consumption; variable operating costs; and capacity factors)--flexicoking operations

- Fluid catalytic cracker: input and produced refinery intennediate process streams

- Pentane/hexane isomerization unit: purchased natural gas, electricity and stean consumption-natural gas

- Hydrocarbon Processing, New Roles for Themal Cracking, May 1980

- Visbreaker and thermal cracker: input and produced refinery internediate process streams

- H ydrocarbon Processing, Review Ways to Upgrade Resids, September 1979

- Delayed coker (refinery intermediate process streams; capacity factor; purchased fuel (natural gas), electricity and steam consumption; and variable operating costs)--clarified oil processing activity 
- Visbreaker and thermal cracker: input and produced refinery intermediate process streans

- Hydrocarbon Processing, Resid Desulfurizer--A Year Later, September 1977

- Vacuum residual desulfurizer: input and produced refinery intermediate process streams--additional activity

- Hydrocarbon Processing, How to Produce FCC Yields, February 1983

- Fluid catalytic cracker: input and produced refinery process streams--additional activities

- Hydrocarbon Processing, New Catalysts Developed for FCC Reduced Crude Desulfurization and Hydrocracking, December 1981

- Fluid catalytic cracker: input and produced refinery intermediate process streams--additional activities

- Hydrocarbon Processing, Feed Sulfur Distribution in FCC Product, May 19, 1975

- Fluid catalytic cracker: input and produced refinery intermediate process streams--additional activities

- Hydrocarbon Processing, Hydrocrack Heavier Feeds, May 1981

- Hydrocracker: input and produced refinery intermediate process streams--additional activities

- Hydrocarbon Processing, Strategy of Isomerization, April 1975

- Pentane/hexane isomerization unit: purchased natural gas, electricity and steam consumption

- How to Predict Coker Yields, September 1983

- Delayed coker (refinery intermediate process streams; capacity factor; purchased fuel (natural gas), electricity and steam consumption; and variable operating costs)--clarified oil processing activity

- The Impact of SOx Emissions Control on the Petroleum Refining Industry, Arthur D. Little, December 1975

- Delayed coker (refinery intermediate process streams; capacity factor; purchased fuel (natural gas), electricity and steam consumption; and variable operating costs)--clarified oil processing activity
- FCC gasoline fractionation: input and produced refinery intermediate process streams--additional activities

- Hydrocracker: input and produced refinery intermediate process streams--additional activities

- Alkylation unit (input and produced refinery intermediate process streams; capacity factor; purchased natural gas, electricity and steam production; and variable operating costs)

- Lube and wax production units: input and produced refinery intermediate process streams; capacity factor; and purchased natural gas, electricity and steam consumption

- Gulf Publishing Company, Hydrocracking Handbook, 1969

- Hydrocracker: input and produced refinery intermediate process streams--additional activities

- Radian Corporation, Assessment of Atmospheric Emission from Petroleum Refining, April 1980

- Sulfur production and hydrogen sulfide recovery: input and produced refinery internediate process streams

- Quoted trade journal prices

- Prices corresponding to classes of demand--natural gasoline

- Marcova, Inc., Pipeline Rates on Crude Petroleum Oil, 1983

- Pipeline transportation rates

- National Petroleum Council, Petroleum Storage and Transponation Capabilities--Petroleum Pipeline, Volume III, December 1979

- Volume movement constraints

- Constraints on joint movements from/to locations-pipeline constraints

- American Tanker Rate Schedule

- Water transportation costs

- World wide Tanker Nominal Freight Scale

- Water transportation costs

- Bureau of Labor Statistics, Producer Price Indices, 1982 
- 1982 price index for total railroad freight.

\section{DOE Data Input Sources:}

\section{Forms and Publications:}

- Energy Information Administration, Form EIA-810, "Monthly Refinery Report"

- Maximum volume available--foreign crude oil

- Energy Information Administration, Form EIA-814, "Monthly Imports Report"

- Crude quality data used to estimate raw material unit costs

- Maximum volume available--foreign crude oil

- Variable volume limitations: foreign gas plant operations and Canadian imports

- Energy Information Administration, Form EIA-820, "Annual Refinery Report"

- Maximum volume available--foreign crude oil

- Maximum (upper) bound, and fixed or equivalency volume--electricity, natural gas, and steam

- Product demands

- Energy Information Administration, Cost and Quality of Fuels for Electric Utility Plants, DOE/EIA-0191, (Washington, DC)

- Sulfur content--very low sulfur

- Energy Information Administration, State Energy Data Repon, DOE/EIA-0214 (Washington, DC)

- Product demands

- Energy Information Administration, Weekly Petroleum Status Repont, DOE/EIA-0208, (Washington, DC)

- Raw material unit costs--first of month prices

- U.S. Department of Energy, Bartlesville Energy Technology Center, Motor Gasolines, DOE/BETC/PPS$82 / 3,83 / 11$

- Gasoline specification, and volatility and lead specifications: octane numbers, average Reid vapor pressure and percentages boiled off

- Energy Information Administration. Monthly Energy Review, DOE/EIA-0035, (Washington, DC, Monthly)

- Raw material unit costs--foreign crude
- Unit cost of electricity and natural gas

- Energy Information Administration, Petroleum Supply Annual, DOE/EIA-0340, (Washington, DC, Annually)

- Minimum and maximum bounds on production

- Gasoline grade production ratios

- Maximum volume available

- Maximum (upper) bound, and fixed or equivalency volume--electricity, natural gas and steam

- Refinery unit capacities (capacity of refinery processing units, capacity utilization bounds, stream day factor and number of refineries per region)

- 1982 total refinery fuel consumption data used to adjust purchased natural gas, electricity, and steam consumption

- Raw material purchases--crude volumes at first increment, and gas liquids volumes and prices for first increment

- Product demands

- Table inventory

- Variable volume limitations (domestic and foreign gas plant opemations, and Canadian imports)

- Refinery processing mode constraints

- Gas plant operations

- Energy Information Administration, Petroleum Marketing Monthly; DOE/EIA-0380, (Washington, DC, Monthly)

- Revenues per unit or prices at refinery gate

- Fixed or equivalency production

- Product demands

- Prices corresponding to classes of demand

Models and Other:

- Energy Information Administration judginent

- Raw material unit costs

- Energy Information Administration, Refinery Evaluation Modeling System (REMS)--Product Sales and Revenue, and Material Balance Purchases and Global Streams tables 
- Material balance

- Energy Information Administration, Refinery Evaluation Modeling System (REMS)--Refinery Yield Model (RYM)

- Raw material purchases: crude volumes and prices at first increment

- Prices corresponding to classes of demand--other

- Definition of refinery operation modes

- Refinery operations for specific scenarios (summary information, refinery input and yield coefficients, refinery operating costs, and capacity constraint coefficient)

- Energy Information Administration, Demand Analysis System

- Price elasticities.

General Output Descriptions: Both the RYM and the ORAD modules produce a series of output reports. RYM reports include: several economic summaries (raw materials costs and volumes, products costs and volumes, and process unit costs and utilization), accounting summaries products produced and revenues gained, and raw materials consumed and associated costs by refinery district), a summary of cutpoint adjustments and miscellaneous transfers, summaries of distillate blending activities (distillate and fuel oil specifications obtained), recipe products summary, matcrial balance summaries by district, raw material production, summaries, petrochemical feedstocks and an LPG composition report, a processing constraints summary for refineries and gas plants, distribution constraints summaries, cost summaries, an inventory utilization report, a summary of imports, and distribution summaries by transportation mode.

\section{Computing Environment:}

- Hardware Used: IBM $3090-400 \mathrm{E}, 3033$ or $360 / 370$ (or equivalent)

- Operating System: OS/VS2 or OS or VS

- Language/Software Used: OMNI Linear Programining System (Haverly Systems) and Mathematical Programming System (MPS) III (Ketron)

- Memory Requirement: $500 \mathrm{~Kb}$

- Storage Requirement: 3350 disk -- 200 tracks for storing the source and load modules

- Estimated Run Tirie: RYM -- 31 CPU seconds; ORAD -- 26-40 seconds
- Special Features: None.

Independent Reviews Conducted:

- Model Quality Audit conducted by the Office of Statistical Standards, June 1988.

- Independent Expert Review conducted by George Lay, June 1988.

Status of Evaluation Efforts by Sponsor: None.

\section{Refinery Yield Model Spreadsheet System (RYMSS-PC)}

Description: RYMSS-PC simulates the operations of a refinery or group of refineries within the United States, including the processing of crude oils and other raw materials, as well as the processing of these raw materials into finished petroleum products. Refinery product yields and net margins are generated which can be used in comparative and sensitivity analyses, using RYMSS-PC.

Last Model Update: June 1993.

Part of Another Model? No.

Model Interfaces: No direct interface. However, since RYMSS-PC process unit yield data was developed (or used directly) from the EIA RYM linear programming model, it can be used in conjunction with RYM.

Sponsor:

- Office: Office of Oil and Gas

- Division: Petroleum Marketing Division

- Branch: Publications and Analysis, EI-432

- Model Contact: Charles Dale

- Telephone: 202-586-1805

Documentation: Energy Information Administration, $R e$ finery Yield Model Spreadsheet System RYMSS-PC Documentation, DOE/EIA-M037 (Washington, DC, April 1989).

Archive Media and Installation Manual(s): RYMSS.WK1 - archived on floppy disk.

Purpose: RYMSS-PC simulates refinery operations in order to perform comparative and sensitivity analyses on refinery product yields and refinery net margins.

Energy System Described by Model: U.S. refinery processes and product production. 


\section{Coverage:}

- Geographic: United States: 50 States and territories, but can be used for any region for which adequate data are available.

- Time Unit/Frequency: The data base contains 1987 annual data. However, because the units used within the model are in terms of rates, the static version of the model can be used over any single period of time. The d'ata base, of course, would have to be revised.

- Product(s): The RYMSS-PC represents the processing of 28 reference crude oils plus unfinished oils and other hydrocarbon inputs in the refinery(s), and the production of more than 20 refinery products using 17 separate, detailed refinery processes.

- Economic Sector(s): None.

\section{Modeling Features:}

- Model Structure: RYMSS-PC is a static simulation model which determines product yields and net refinery margins given input data on crude oils and other raw material inputs (type, and volume), product prices (and volume for a few select products), finished motor gas specifications (octane and Reid vapor pressure), and refinery configuration.

- Modeling Technique: Static simulation.

- Special Features: An inportant feature of RYMSSPC is that the major petroleum products (motor gasoline, jet fuels, distillate, and residual) can be blended to specification. (When product specifications are not met the message 'non spec' will be given.) This feature allows an excellent representation of the refinery adjustments necessary to produce products to specifications. Input tables within RYMSS-PC define specifications such as Reid vapor pressure, viscosity, flash point, octane rating, API gravity, and sulfur content. Another special feature is provided through the RYMSS-PC to automatically converge upon the reformer severity necessary to produce motor gasoline at a predetermined pool octane rating across a range of Reid vapor pressure settings.

\section{Non-DOE Input Sources:}

- Platt's Oilgram Price Report, McGraw-Hill, New York

- Crude oil inputs: unit purchase cost, API gravity and weight percent sulfur

- Unfinished oils and other hydrocarbon inputs: unit purchase cost

- Product control variables: price (petrochemical feeds and unfinished naphtha)
- Petroleum Intelligence Weekly, New York

- Crude oil inputs: unit purchase cost, API gravity and weight percent sulfur

- Oil Buyers' Guide: The Authoritative Newsletter on Market Prices, Lakewood, NJ

- Crude oil inputs: unit purchase cost, API gravity and weight percent sulfur

- Unfinished oils and other hydrocarbon inputs: unit purchase cost

- Product control variables: price (butane)

- Alcohol Outlook, Information Resources Inc., Washington, DC

- Unfinished oils and other hydrocarbon inputs: unit purchase cost

- Product control variables: price (petrochemical feeds (aromatics: benzene, toluene, xylene))

- Oil and Gas Joumal, Annual Refinery Report, March, annually

- Process unit capacity and utlization control variables: operable capacity

- Oil and Gas Joumal, November 7, 1988, and November 4,1985 , issues

- 1987 and 1982 Nelson-Farrar cost indices

- U.S. Bureau of Mines

- Product control variables: price (sulfur)

- J.H. Gary and G.E. Handwerk, Petroleum Refining Technology and Economics, 2nd ed. (New York: Marcel Dekker, Inc., 1984), p. 174

- Alkylation yiclds

- A.M. Brownstein, Petrochemical Technology (Tulsa, OK: The Petroleum Publishing Co., 1976), p. 25

- Aromatics recovery yields

- The Chemical Marketing Reponter

- Product control variables: price (propylene, asphall, lubes and waxes).

DOE Data Input Sources: 
Forms and Publications:

- Energy Information Administration, Form EIA-782A, 'Refiners'/Gas Plant Operators' Monthly Petroleum Product Sales Report"

- Motor gasoline specifications control variables: percent of total motor gasoline yield

- Energy Information Administration, Form EIA-782B, 'Reseller/Retailer's Monthly Petroleum Product Sales Report"

- Motor gasoline specifications control variables: percent of total motor gasoline yield

- Energy Information Administration, Form EIA-810, "Monthly Refinery Report"

- Crude oil inputs: volume

- Unfinished oils and other hydrocarbon inputs: volume

- Process unit capacity and utilization control variables (operable capacity and utilization rate)

- Product control variables: volume

- Energy Information Administration, Form EIA-820, "Annual Refinery Report"

- Process unit capacity and utilization control variables (operable capacity and utilization rate)

- Energy Information Administration, Form EIA-856, "Monthly Foreign Crude Oil Acquisition Report"

- Crude oil inputs: unit purchase cost, API gravity and weight percent sulfur

- Energy Information Administration, Petroleum Supply Annual, DOE/EIA-0340, (Washington, DC)

- Process unit capacity and utilization control variables (operable capacity and utilization rate)

- Energy Information Administration, Petroleum Supply Monthly, DOE/EIA-0109, (Washington, DC)

- Unfinished oils and other hydrocarbon inputs: volume

- Total motor gasoline yields used to calculate motor gasoline specifications control variables (percent of total motor gasoline yield)

- Fresh feed inputs used to derive process unit capacity and utilization control variables: utilization rate (catalytic cracking, hydrocracking and coking units)

- Energy Information Administration, Petroleum Marketing Monthly, DOE/EIA-0380, (Washington, DC)

- Crude oil inputs: unit purchase cost, API gravity and weight percent sulfur

- Sales volumes used to calculate motor gasoline specifications control variables (percent of total motor gasoline yield)

- Energy Information Administration, Petroleum Marketing Annual, DOE/EIA-0487, (Washington, DC) (Tables 2, 4, 5, and 11)

- Product control variables: price (motor gasoline, aviation gasoline, propane, kerosene, No. 2 distillate, residual fuel oil)

- Energy Information Administration, Monthly Energy Review, DOE/EIA-0035, (Washington, DC)

- Product control variables: price (still (natural) gas, power)

- Energy Information Administration, Cost and Quality of Fuel for Electric Utility Plants 1987, DOE/EIA-0191, (Washington, DC)

- Product control variables: price (petroleum coke)

Models and Other:

- Energy Information Administration, Refinery Yield Model (RYM)

- Crude oil distillation (yield and sulfur content)

- Coking unit yields

- Visbreaker yields

- Fluid catalytic cracker yields

- Hydrocracking yields

- Catalytic reforming yields

- Isomerization yields

- Alkylation yields

- Aromatics recovery yields

- Hydrotreater yields 
- Operating costs

- Gasoline blending

- Jet fuel blending

- Distillate and residual fuel oil blending.

General Output Descriptions: RYMSS-PC produces three output reports through the use of macro functions. RYMSS-PC reports include:

- The 'Input Summary' - raw material costs and volumes, products costs and volumes, and process unit configurations.

- The 'Comparison' tables - comparison of the base case and an alternative (current) case 'input summary.'

- The 'Refinery Output, Net Margin, and Process Summary' - product yields, prices, and revenue summary, refinery net margin accounting summary, and process unit input and output summaries.

Computing Environment:

- Hardware Used: IBM-compatible personal computer

- Operating System: MS DOS

- Language/Software Used: Lotus 1-2-3, Version 2.0 or higher

- Memory Requirement: Approximately $250 \mathrm{~Kb}$

- Storage Requirement: $250 \mathrm{~Kb}$

- Estimated Run Time: $\mathbf{5}$ seconds recalculation time on an 80386 PC operating under DOS 5.0, macro function/0 (optional) can take up to 2 minutes.

- Special Features: None.

Independent Reviews Conducted: Internal: William Robinson, EIA Office of Statistical Standards, February 1991. External: Prof. Adam Rose, Pennsylvania State University, July 1990; Washington Consulting Group, October 1990.

Status of Evaluation Efiorts by Sponsor: Final Validation Report for Refinery Yield Model Spreadsheet System, Decision Analysis Corporation, Vienna, VA, January 18, 1991.

\section{Residential Energy End-Use De- mand Model (REEM)}

Description: REEM forecasts energy use by type of fuel annually through the year 2010 . It is an end-use structural model, with emphasis on fuel-using technologies and effíciencies. The model forecasts fuel use by type and vintage of house, by service demand and on a regional basis for four Census regions. It is sensitive to the major demographic and economic determinants of residential sector energy use.

Last Model Update: September 1991.

Part of Another Model? Part of the Intermediate Future Forecasting System.

Model Interfaces: A nnual Energy Outlook 1991 Forecasting System (IFFS/GAMS/DEMS). Model also operates as stand alone.

Sponsor:

- Office: Office of Integrated Analysis and Forecasting

- Division: Energy Demand and Integration Division

- Branch: Energy Demand and Analysis Branch

- Model Contact: Barry Cohen

- Telephone: 202-586-5359

Documentation: Energy Information Administration, PCAEO Forecasting Model for the Annual Energy Outlook 1991, Model Documentation (Section 2, Residential Energy Demand), DOE/EIA-M036(90) (Washington, DC, March 1990) and Technical Notes.

Archive Media and Installation Manual(s): IFFS93 - Archived as part of the Intermediate Future Forecasting System.

Purpose: The primary purpose and use of the model is to prepare long-term projections of residential energy consumption for the Annual Energy Outlook.

Energy System Described by Model: The energy system is the residential demand for fuel on a regional and end-use basis, and the behavior of this demand over the forecast period.

Coverage:

- Geographic: Four Census regions

- Time Unit/Frequency: Annual, 1987 through 2010

- Product(s): Electricity, natural gas, distillate, kerosene, liquid gas and coal; renewables is an exogenous input

- Economic Sector(s): Residential.

Modeling Features: 
- Model Structure: Energy and fuel use based on the number of houses, service demand and a logistic analysis of life-cycle costs of fuel using technologies. The model is recursive by Census region.

- Modeling Technique: End-use Simulation Model

- Special Features: None.

Non-DOE Input Sources:

- DRI/McGraw-Hill, Macroeconomic Model

- U. S. housing starts

- Bureau of the Census, Characteristics of New Housing 1991, Current Construction Reports C25-91-A

- Housing type shares (through 1991)

- Initial market share; electric heat pump (heating \& cooling)

- Bureau of the Census, Annual Housing Survey 1983 and Components of Inventory Change 1983

- Demolition rate

- Bureau of the Census, Current Housing Reports, General Housing Characteristics for the U.S. and Regions: 1983

- Demolition rate

- Lawrence Berkeley Laboratories, Energy Efficiency Technologies for Residential and Commercial Buildings, April 17, 1989

- Operations and maintenance cost, initial market share, and initial 1987 capital cost, required energy output and equipment efficiency: refrigeration (electric), electric air conditioning and gas furnaces

- Pacific Northwest Laboratories, Technical Support Document: Automated Residential Energy Standard, PNL-6979, Vol. 2, May 1989

- Operations and maintenance cost, initial market share, and initial 1987 capital cost, required energy output and equipment efficiency: electric heat pump (heating and cooling) and electric baseboard heat

- Harry Chernoff, Individual Purchase Criteria for Energy-Related Durables: The Misuse of Life-Cycle Cost, Vol. 4, No. 4, The Energy Joumal 1983

- Discount rate
- Energy Guide Labels

- Equipment efficiency: hot water heaters.

\section{DOE Data Input Sources:}

Forms and Publications:

- Energy Information Administration, Forms EIA457A/G, "Residential Energy Consumption Survey"

- Housing stocks (initial 1987)

- Total fuel use in Btu of each fuel

- Energy Information Administration, Housing Characteristics 1987, DOE/EIA-0314(87), (Washington, DC)

- Housing stocks (initial 1987)

- Conservation and Renewable Energy Division, Technical Suppon Document: In Support of Interim Energy Conservation Standards, DOE/CE-0223, Vol. 2, June 1988

- Operations and maintenance cost, initial market share, and initial 1987 capital cost, required energy output and equipment efficiency: Hot water heaters, electric air conditioning, and oil and gas furnaces

- Energy Information Administration, State Energy Data Report: Consumption Estimates, 1960-1990, DOE/EIA-0214 (Washington, DC, May 1992)

- Consumption data

- Energy Information Administration, State Energy Price and Expenditures Repont, DOE/EIA-0376, (Washington, DC)

- Price data

Models and Other:

- Energy Information Administration, Forecasting System, Annual Energy Outlook 1993

- Fuel prices.

General Output Descriptions: Energy consumption for six residential sector fuels by four Census regions.

Computing Environment:

- Hardware Used: IBM 3084QX

- Operating System: MVS/XA

- Language/Software Used: IBM FORTRAN 
- Memory Requirement: $350 \mathrm{~Kb}$

- $\quad$ Storage Requirement: 150 tracks of IBM 3380 disk drive

- Estimated Run Time: 10 minutes in an integrated mode on an IBM 3084 QX

- Special Features: The model requires accompanying datafiles which require $100 \mathrm{~K}$ of storage space.

Independent Reviews Conducted: Independent Expert Review conducted by Eric Hurst and Russell Lee of Oak Ridge National Laboratory, June 1991.

Status of Evaluation Efiorts by Sponsor: None.

\section{Resource Allocation and Mine Costing Model (RAMC)}

Description: RAMC produces the quantity-price relationships in coal supply for 30 coal types (further distinguished between surface and deep mines) and 32 producing regions based on the 1991 EIA Demonstrated Reserve Base, engineering estimates of mining costs for various surface and underground mines, and region-specific and coal-typespecific cost elements. This model serves as a major component of the Intermediate Future Forecasting System, the National Coal Model, the International Coal Trade Model, and the Coal Supply and Transportation Model.

Last Model Update: December 1991.

Part of Another Model? Intermediate Future Forecasting System (IFFS), National Coal Model (NCM), International Coal Trade Model (ICTM), and Coal Supply and Transportation Model (CSTM).

Model Interfaces: Coal Supply and Transportation Model, National Coal Model, International Coal Trade Model, and Intermediate Future Forecasting System.

Sponsor:

- Office: Office of Integrated Analysis and Forecasting

- Division: Energy Supply and Conversion Division

- Branch: Coal, Uranium and Renewable Fuels Analysis Branch, EI-822

- Model Contact: Mike Mellish

- Telephone: 202-585-2136

Documentation:

- Energy Information Administration, Documentation of the Resource Allocation and Mine Costing (RAMC)
Model, DOE/EIA-M021 (Washington, DC, January 1992).

- Energy Information Administration, RAMC Surface Mining Cost Equations Development, DOE/EIA-0433 (Washington, DC, September 1983).

- Energy Information Administration, RAMC Underground Mining Cost Equations Development, DOE/EIA-0432 (Washington, DC, September 1983).

- Energy Information Administration, Documentation of the Reserve Related Data Inputs to the Resource Allocation and Mine Costing Model, DOE/NBB-0026 (Washington, DC, September 1982).

- Energy Information Administration, Documentation of the Resource Allocation and Mine Costing (RAMC) Model, DOE/EIA-MO21 (Washington, DC, May 1987).

- Reclamation Cost Inputs for the Resource Allocation and Mine Costing Model, Science Applications International Corporation (November, 1984). Prepared for EIA.

- Coal Preparation, Science Applications International Corporation, (June 1984). Prepared for EIA.

Previous Documentation:

- Coal and Electric Utilities Model Documentation, ICF, Incorporated, (May 1980).

Archive Media and Installation Manual(s):

- RAMC79 - for the Annual Repont to Congress (ARC) 1979

- RAMC80 - for the Annual Repon to Congress (ARC) 1980

- RAMC81 - for the Annual Repon io Congress (ARC) 1981

- RAMC82 - for the Annual Energy Outlook (AEO) 1982

- RAMC82A - for the Clean Air Act Study

- RAMC982 - for the 1982 documentation

- RAMC83 - for the Annual Energy Outlook (AEO) 1983

- RAMC84 - for the Annual Energy Outlook (AEO) 1984

- RAMC85 - for the Annual Energy Outlook (AEO) 1985

- RAMC86 - for the Annual Energy Outlook (AEO) 1986

- RAMC91 - for the Annual Energy Outlook (AEO) 1991 
- RAMC92 - for the Annual Energy Outlook (AEO) 1992.

Purpose: The RAMC is used to develop coal supply curves for EIA's coal supply models. It can be used to analyze the impact of changes in coal supply or costs resulting from changes in taxes, production and preparation costs, productivity, coal reserves and other supply-related costs.

Energy System Described by Model: Potential coal supply at various minemouth prices.

\section{Coverage:}

- Geographic: Supply curves for 32 coal-producing regions

- Time Unit/Frequency: 1990 through 2010 curves

- Product(s): 30 coal types

- Economic Sector(s): Coal.

Modeling Features:

- Model Structure: The RAMC employs a structural approach using engineering and economic algorithms.

- Modeling Technique: Two steps: (1) calculates reserves and (2) determines minimum acceptable selling price.

- Special Features: None.

Non-DOE Input Sources:

- BCOA Hikes Benefits Contributions: Fund Shortfalls Force \$1/Hour Increase, article in Coal Week, McGrawHill, September 3, 1990

- Data on current employer contribution levels to each of the pension and trust fund plans of the United Mine Workers of America, used to derive welfare fund estimates

- Keystone Coal Industry Manual, McGraw-Hill, 1981, 1982, and 1985

- Data used to adjust committed reserves estimates

- Information used to supplement seam depth estimates

- Coal Industry Taxes, compiled by Donna Summons for McGraw-Hill's Mine Regulation and Productivity Report, 1981

- State and/or Local taxes
- Science Applications International Corporation, Development of RAMC Longwall Model Mines, unpublished Final Report prepared for U.S. Department of Energy, Energy Information Administration, March 1991

- Revised mine size distribution parameters (for the four largest underground size categories)

- Science Applications International Corporation, Enhancement of Short-Tenn Coal Supply Modeling Capabilities, unpublished Final Report prepared for U.S. Department of Energy, Energy Information Administration, March 1989

- Capacity utilization data, used to estimate current coal-mine production capacity

- Science Applications International Corporation, Development of Revised Reserve Inputs to the Resource Allocation and Mine Costing Model, May 1986

- Data used to adjust committed reserves estimates

- Data used to adjust clean coal yield estimates (certain regions

- Science Applications International Corporation, Revisions to the Overburden Ratio and Current Price Inputs to the $R A M C$, unpublished Final Report prepared for U.S. Department of Energy, Energy Information Administration, May 1986

- Overburden ratio distribution parameters

- Science Applications International Corporation, "Reclamation Cost Inputs for the Resource Allocation and Mine Costing Model," unpublished Final Working Paper prepared for U.S. Department of Energy, Energy Information Administration, November 1984

- Reclamation Costs

- Science Applications International Corporation, Coal Preparation, unpublished Final Report prepared for U.S. Department of Energy, Energy Information Administration, June 1984

- Preparation costs (basic cleaning costs)

- ICF, Inc., "Coal and Electric Utilities Model Documentation," unpublished Draft Report, May 1980

- Clean coal yields

- ICF, Inc., "Further Analysis of Alternative New Source Performance Standards for New Coal-Fired Power Plants," unpublished Drafi Report prepared for U.S. Environmental Protection Agency and U.S. Department of Energy, September 1978 
- Mine lives

- ICF, Inc., Effects of Altemative New Source Performance Standands for Coal-Fired Electric Utility Boilers on the Coal Markets and on Utility Expansion Plans, 1978

- Inaccessible reserves fractions

- ICF, Inc., 'Coal and Electric Utilities Model Documentation," unpublished report, July 1977

- License fee

- Paul P. Derienzo and Peter J. Phillips, Steam Coal Preparation Economics, paper presented before the Second Symposium on Coal Preparation, Louisville, KY, October 19-21, 1976

- Clean coal yields

- Mine Safety and Health Administration roof control plans

- Seam depth

- Various State mining reports

- Information used to supplement seam depth estimates

- Personal knowledge of analysts who developed the inputs

- Information used to supplement seam depth estimates (for some mines)

- Mine permit applications on file at State reclamation offices and Federal Office of Surface Mining library in Denver, CO

- Reclamation costs (earthmoving tasks)

- Mine permit applications on file at the Kentucky, Virginia, Illinois and Pennsylvania State regulatory agencies, and the Federal Office of Surface Mining library in Denver, $\mathrm{CO}$

- Reclamation costs (earthmoving tasks)

- Mine permit applications prepared by Science Applications International for clients in Kentucky and Tennessee

- Reclamation costs (earthmoving tasks)

- Ground control plans on file at Mine Safetyand Health Administration, District and Subdistrict Offices
- Data used to estimate overburden ratio distribution parameters

- Illinois Department of Mines and Minerals, Determination of Bonding Costs, (procedure description), February 1983

- Reclamation costs (estimates of the typical costs of revegetation in the Midwest)

- Illinois Department of Mines and Minerals, $1980 \mathrm{An}$ nual Coal, Oil and Gas Repon, May 1981

- Data used to estimate overburden ratio distribution parameters

- Synergic Resources, Corp. Documentation of the Demonstrated Reserve Base of Coal in the United States, "Vol. 2, unpublished Final Report prepared for U.S. Department of Energy, Energy Information Administration, March 1982

- Maximum depth representing the Demonstrated Reserve Base limit for surface mining, used in calculation of overburden ratio distribution parameters

- Consolidated Omnibus Budget Reconciliation Act of 1986

- Black lung payments

- U.S. Department of the Interior

- Abandoned Mine Reclamation Fees

- Data used to estimate percentage of each region's 1988 production mined by operations on Federally-leased lands

- Federal coal royalty rates

- National Coal Association, Summary of Coal Severance and Production Taxes, November 1990

- Severance taxes

- State Taxes on Coal: A Compendium of 1982 Statutes, Rand Corp., 1982

- State and/or local taxes

- Commerce Clearinghouse Inc., The State Tax Handbook as of October I, 1988 and 1989

- Updates (in many regions) to State and/or local taxes

- Commerce Clearinghouse Inc., Topical Law Reports 
- State corporate income tax rates

- Western Mine Engineering, Mine Cost Service, Spokane, WA 1989

- Updates (in many regions) to State and/or local taxes

- State corporate income tax rates (Alaska, Missouri and Montana)

- National Council on Compensation Insurance

- Current exposure insurance rates for the coal industry (most States)

- State Worker's Compensation offices and other State agencies

- Exposure insurance (some States)

- Caterpillar Tractor Co., Caterpillar Perfonnance Handbook, Edition 11, 1980

- Reclaunation costs (equipment operating costs, and owning and labor costs for equipment not used by the model mines)

- Caterpillar Tractor Co., Caterpillar Performance Handbook, Edition 8, 1977

- Reclamation costs (cycle times for haulage equipment)

- Skelly and Loy, "Abandoned Mine Land Prototype Reclamation Costs," unpublished report prepared for Kentucky Department for Natural Resources and Environmental Protection, 1981

- Reclamation costs (estimates of the typical costs of revegetation in Central Appalachia)

- Skelly and Loy, "Analysis of the Impact of Public Law 95-87 on Mining Performance," unpublished report prepared for U.S. Department of Energy, June 1979

- Reclamation costs (permitting costs in the Midwest and West)

- Fred C. Hart Associates, "Reclamation Bond Estimation for Mine Plan Review," unpublished report prepared for U.S. Department of the Interior, Office of Surface Mining, August 1981

- Reclamation costs (estimates of the typical costs of revegetation in Northern Appalachia)

- 1984 winning bids submitted by contractors to the Commonwealth of Pennsylvania for the reclamation of abandoned mine sites
- Reclamation costs (estimates of the typical costs of revegetation in Northern Appalachia)

- Engineering contractors that prepare applications for mining companies

- Typical permit application rates in Appalachia, used to calculate reclamation costs (permitting costs)

- U.S. Environmental Protection Agency, James J. Stukel, Advanced Utility Simulation Model Analytical Documentation; State Level Model (Version 1.0), Appendix C.-Coal Cleaning Methodology (J.F. Skea and E.S. Rubin), EPA-600/8-88-071a, January 1989

- Regression equations used to calculate preparation costs

- J.M Mutmanshky et. al., Mine Cost Analysis and Control, Handout for short course at Penn State University, April 9-11, 1990

- Data on average unit productivity of a sample of 69 continuous miner operations, used to determine capital productivity adjusuments factors

- U.S. Department of the Treasury, Internal Revenue Service

- Federal corporate income tax rate.

\section{DOE Data Input Sources:}

\section{Forms and Publications:}

- Energy Information Administration, Annual Energy Review 1990, DOE/EIA-0384(90)

- Gross National Product deflators

- Energy Information Administration, Bituminous Coal and Lignite Production and Mine Operations--1978. DOE/EIA-0118(78)

- Average regional overburden ratios

- State-level labor productivity data, used to develop labor productivity adjustment factors

- Energy Information Administration, Coal Production, DOE/EIA-0118 (various years)

- Demonstrated Reserve Base of coal in the United States as of January 1, 1991, used to estimate total reserves

- Recoverable reserve data, used to develop estimates of committed reserves 
- Data used to derive original mine size distribution parameters

- 1984 average regional overburden ratios

- Data used to es:imate percentage of each region's 1988 production mined by operations on Federally-leased lands

- 1989 State-level labor productivity data, used to develop labor productivity adjustment factors

- Production ciata used in conjunction with coalmine capacity utilization data to estimate current production capacity and fraction of current pro duction surface-mined

- Minemouth price data, used to estimate current price

- Energy Information Administration, Quarterly Coal Repor, DOE/EIA-0121(90/2Q), November 1990

- State corporate income tax rates, "est Virginia regions)

- Energy Information Administration, Coal Analysis File

- Btu and sulfur content data, used to distribute Demonstrated Reserve Base estiunates by coal type

- Energy Information Administration, Forms EIA-7A, "Coal Production Report - 1983 Supplement"

- Total reserves

- Committed reserves

- 1980 recoverable reserve and production data, used to modify mine lives estimates for small surface mines

- 1980 data used to derive recovery factors

- Data used to derive adjustunents to clean coal yield estimates (certain regions)

- 1984 data summarized to derive original mine size distribution parameters

- Seam thickness data for operating mines

- 1983 data used to estimate overburden ratio distribution parameters

- 1983 data used to estimate current production and price, and fraction of current production surfacemined
- Energy Information Administration, RAMC Surface Mining Cost Equations Development, DOE/EIA-432, prepared by Science Applications International Corporation, September 1983

- Model mine cost equations, used to develop reclamation costs (earthmoving tasks)

- Reclamation costs (production capabilities for excavation equipment)

- Energy Information Administration, Documentation of the Reserve-Related Data Inputs to the Resource Allocation and Mine Costing Model, DOE/NBB-0026, prepared by Synergic Resources Corp. and Oak Ridge National Laboratory, September 1982

- 1980 recoverable reserve and production data used to modify mine lives estimates for small surface inines

- Recovery factors

- Mine size categorics (surface mines and three smallest underground categories)

- Seam depth

- Seam thickness

- Overburden ratio categories

- Energy Information Administration, Letter from Jack A. Simon, Chief of Illinois State Geological Survey, to Frank J. Doyle, then Dir. of EIA Eastern Energy Data Field Otfice, February 1981, published in Energy Information Administration, Demonstrated Resene Base of Coal in the United States on January 1,1979 (DOE/EIA-0280(79))

- Inaccessible reserves fractions (Illinois surface reserves)

Energy Information Administration, Economic Growth Rate Assumptions for the 1992 AEO, Memorandum from Calvin Kilgore dated August 1, 1991

- Gross National Product deflators for the last year in the forecast period

- Energy Information Adininistration, "Update of Underground and Surface Mine Size Distribution Factors for AEO 1986," Memorandum (December 2, 1986) to Robert O. Crockett from Mary K. Paull

- Original mine size distribution parameters

Models and Other: 
- Energy Information Administration, Resource Allocation and Mine Costing (RAMC) Model--Model definitions and assumptions

- Supply region

- Coal type

- Model mine regions

- Energy Information Administration, Review of forecasts generated by Coal Supply and Transportation Model (CSTM)

- Modified seam depth estimates

- Modified overburden ratio distribution parameters

- Modified reclamation costs

- Modified labor productivity adjustment factors

- Energy Information Administration, Energy Supply and Conversion Division Estimates

- Utility discount rate (estimated at 4.28 percent assuming a mixed capital structure)

- Coal industry rate of return (calculated from an assumed 8 percent rate of return)

General Output Descriptions: Coal supply curves for the Energy Information Administration's coal supply models. RAMC can be used to analyze the impact of changes in coal supply or costs caused by various factors.

\section{Computing Environment:}

- Hardware Used: IBM 3084

- Operating System: MVS/XA

- Language/Software Used: FORTRAN (G1 compiler)

- Memory Requirement: $1024 \mathrm{~Kb}$

- Storage Requirement: $35 \mathrm{~Kb}$

- Estimated Run Time: Approximately 47 CPU seconds for one complete set of supply curves

- Special Features: None.

Independent Reviews Conducied:

- Model Quality Audit was conducted by the Office of Statistical Standards, November 1990.
- Independent Expert Review was conducted by Stanley Suboleski, July 1988.

Status of Evaluation Efforts by Sponsor: None.

\section{Revenue Requirements Modeling System (RRMS)}

Description: The RRMS is designed to estimate the impacts of various regulatory and economic policy variables on the revenue requirements of individual electric utilities. The model assesses the impact of changes in construction work in progress

(CWIP), in rate base policies, capital structures, costs of capital, and demand on total estimated revenue requirements.

Last Model Update: February 1987.

Part of Another Model? The Single Asset Model (SAM) and the Revenue Requirements Model (RRM) combine to form the Revenue Requirements Modeling System (RRMS).

Model Interfaces: Financial Information Analysis System (FIAS).

\section{Sponsor:}

- Omce: Office of Integrated Analysis and Forecasting

- Division: Energy Supply and Conversion Division

- Branch: Nuclear and Electricity Analysis Branch, EI821

- Model Contact: Art Holland

- Telephone: 202-586-2026

Documentation: Revenue Requirements Modeling System Documentation (RRMS), International Energy Associates, Limited, DOE/PE/70403, March 1986.

- $\quad$ Volume I, Appendices A-C, March 1987.

- Volume II, Appendices D-E, March 1987.

- Volume III, Appendices F-H, March 1987.

- Volume IV, Appendix I, December 1987.

Archive Media and Installation Manual(s):

- RRM85 - for the 1985 Annual Energy Outlook

- RRM85A - Archived for The President's Tax Proposal 
- RRMS86 - for the Investor-Owned Electric Utilities Study.

Purpose: The RRMS estimates the cost of service of the electric operations of investor-owned electric utilities utilizing a simplified regulatory accounting framework. The RRMS specifically addresses the following components of revenue requirements: return on investment, depreciation expense, fuel expenses, nonfuel operations and maintenance expenses, and other (gross receipts) taxes.

Energy System Described byModel: RRMS produces electric utility financial information.

\section{Coverage:}

- Geographic: Single utility

- Time Unit/Frequency: Annual

- Product(s): Pro forma financial statements

- Economic Sector(s): Electric utilities.

Modeling Features:

- Model Structure: The methodology used in the RRMS consists of three basic steps. First, a generalized cost-of-service framework is constructed. Second, an external data file interface provides the regulatory and economic environment to be studied by assigning values to key model parameters and variables. Finally, the user is able to produce standard preformatted reports designed to highlight the impacts of the assumed change in regulatory or economic environments.

- Modeling Technique: RRMS is a deterministic model that estimates certain financial relationships based on a simplified accounting framework represented by a series of linear equations.

- Special Features: RRMS uses either a SAS data set or a sequential card inage file for input data. In addition, the current version of RRMS allows the user to assess the likely impacts of various provisions of the Tax Reform Act of 1986.

\section{Non-DOE Input Sources:}

- 1987 memo from Mark Inglis, ICF, Inc. to John Conti, DOE/Energy Information Administration

- Construction Work in Progress (CWIP) in rate base.

\section{DOE Data Input Sources:}

Forms and Publications: Energy Information Administration, Form EIA-860, "Annual Electric Generator Report"
- Capacity

- Heat rates

- Company ID

- Plant ID

- Plant name

- Plant type

- Unit ID

- National Coal Model (NCM) coal region code

- Date plant comes on line

- Ownership type

- Percent owned by each company

- Residual type code

- Percent of year plant in service Federal Energy Regulatory Commission, FERC Form 1, "Annual Report of Major Electric Utilities, Licensees and Others"

- Operations and maintenance costs (fixed and variable)

- Cost of capital

- Total assets

- Debt

- Accumulated deferred taxes

- Net electric plant

- Net nuclear fuel

- Net common plant

- Investments in subsidiaries

- Equity

- Electric construction work in progress (CWIP)

- Capitalization fractions

- Electric working capital

- Electric operations share factor

- Utility code

- Company name 
- Ticker symbol

- Region

- Company share factor

- Value of assets net of allowance for funds used during construction (AFUDC)

- Transmission and distribution costs

Models and Other: Energy Information Administration, Intermediate Future Forecasting System (IFFS)

- Fuel costs

- GNP deflator

- Capacity factors

- Cost of capital

- Tax rates

- Year

- Sales

- Private/public share factor

- Loss fraction

- Load factor

- Transmission and distribution costs.

General Output Descriptions: The RRMS generates pro forma financial statements for evaluation of changes in electric utility policy and regulation. These data are used to produce a series of reports on a base case and a hypothetical case to summarize key financial output variables.

\section{Computing Environment:}

- Hardware Used: IBM 3084 or $360 / 370$ (or equivalent)

- Operating System: OS or VS

- Language/Software Used: PL/1 and SAS (Version 5.16)

- Memory Requirement: $2000 \mathrm{~Kb}$

- Storage Requirement: 3380 -- 100 tracks permanent, 1000 tracks temporary

- $\quad$ Estimated Run Time: On an IBM 3084QX operating under MVS/XA, typically less than 29 CPU seconds for one company.
- Special Features: None.

Independent Reviews Conducted:

- Model Quality Audit was conducted by the Office of Statistical Standards, August 1990.

- Independent Expert Review was conducted by $\mathbf{H}$. Thompson, August 1990.

Status of Evaluation Efiorts by Sponsor: On-going.

\section{Short-Term Coal Analysis System (SCOAL)}

Description: SCOAL projects domestic coal production, imports, consumption, and exports 6 to 8 quarters into the future, based on assumed trajectories of coal prices relative to prices of other fuels, electric generation, industry activity, and weather variables. All markets are defined at the national level except bituminous coal and lignite production, which are defined at the State level.

Last Model Update: January 1990.

Part of Another Model? No

Model Interfaces: SCOAL bases its projections on assumed relative energy price trajectories, domestic and foreign steel industry activity, domestic coal-based generation capacity and utilization, other industry activity levels, and heating degree-days. The assumptions may be drawn from: Data Resources, Inc., macroeconomic forecasts (or similar sources, e.g., Chase Econometrics), forecasts from the Shon-Term Energy Outlook, the A nnual Repont to Congress, or other user-specified sources. SCOAL's coal production forecasts are used by the Short-Term Integrated Forecasting System and are published in the Short-Term Energy Outlook.

Sponsor:

- Office: Office of Coal, Nuclear, Electric and Alternate Fuels

- Division: Analysis and Systems Division

- Branch: Supply Analysis Branch, EI-532

- Model Contact: B. D. Hong

- Telephone: 202-254-5365

Documentation:

- Energy İnformation Ádminisiraiion, Shont-Temi Coal Analysis System (SCOAL) Model Documentation Abstract, DOE/EIA-0394, (EX), (Washington, DC, April 1983). 
- Energy Information Administration, Short-Tenn Coal Analysis System (SCOAL) Model Documentation, Volume 1, Model Overview, DOE/EIA-0394, (Washington, DC, April 1983).

- Energy Information Administration, Short-Tenn Coal Analysis System (SCOAL) Model Documentation, Volume 2, Model Description, DOE/EIA-0394, (Washington, DC, April 1983).

- Energy Information Administration, Shori-Tenn Coal Analysis System (SCOAL) Model Documentation, Volume 3, Data Documentation, DOE/EIA-0394, (Washington, DC, September 1984).

- Previous Documentation: Update and Documentation of the Short-Term Demand and Supply Model, JWK International Corp., September 1982.

Archive Media and Installation Manual(s):

- SCOAL - for the existing documentation

- SCOAL82 - for the Short-Temn Energy Outlook (STEO) 4th Quarter 1982

- SCOAL83A - STEO 1st Quarter 1983

- $\quad$ SCOAL83B - STEO 2nd Quarter 1983

- SCOAL83C - STEO 3rd Quarter 1983

- $\quad$ SCOAL83D - STEO 4th Quarter 1983

- SCOAL84A - STEO 1st Quarter 1984

- $\quad$ SCOAL84B - STEO 2nd Quarter 1984

- SCOAL84C - STEO 3rd Quarter 1984

- SCOAL84D - STEO 4th Quarter 1984

- SCOAL85A - STEO 1st Quarter 1985

- $\quad$ SCOAL85B - STEO 2nd Quarter 1985

- SCOAL85C - STEO 3rd Quarter 1985

- SCOAL85D - STEO 4th Quarter 1985

- SCOAL86A - STEO 1st Quarter 1986

- $\quad$ SCOAL86B - STEO 2nd Quarter 1986

- SCOAL86C - STEO 3rd Quarter 1986

- SCOAL86D - STEO 4th Quarter 1986

- SCOAL87A - STEO 1st Quarter 1987
- SCOAL87B - STEO 2nd Quarter 1987

- SCOAL87C - STEO 3rd Quarter 1987

- SCOAL87D - STEO 4th Quarter 1987

- SCOAL88A - STEO 1st Quarter 1988

- SCOAL88B - STEO 2nd Quarter 1988

- SCOAL88C - STEO 3rd Quarter 1988

- SCOAL88D - STEO 4th Quarter 1988

- SCOAL89A - STEO 1st Quarter 1989

- SCOAL89B - STEO 2nd Quarter 1989

- SCOAL89C - STEO 3rd Quarter 1989, and the Quarterly Coal Repon, A pril-June 1989

- SCOAL89D - STEO 1st Quarter 1990, and the Quarterly Coal Repont, July-September 1989

- SCOAL90A - STEO 2nd Quarter 1990, and the Quarterly Coal Repon, October-December 1989

- SCOAL90B - STEO 3rd Quarter 1990

- SCOAL9OC - STEO 4lh Quarter 1990

- SCOAL90D - STEO 1st Quarter 1991, and the Quarterly Coal Repon, October-December 1990

- SCOAL91A - STEO 2nd Quarter 1991 and the Quarterly Coal Repon, January - March 1991

- SCOAL91B - STEO 3rd Quarter 1991 and the Quarterly Coal Repon, April - June 1991

- SCOAL91C - STEO 4th Quarter 1991 and the Quarterly Coal Repon, July - September 1991

- SCOAL91D - STEO 1st Quarter 1992 and the Quarterly Coal Repont, October - December 1991

- SCOAL92A - STEO 2nd Quarter 1992

- SCOAL92C - STEO 3rd Quarter 1992

- SCOAL92D - STEO 4th Quarter 1992

- SCOAL93A - STEO 1st Quarter 1993.

Purpose: SCOAL is used to support preparation of shortterm projections of bituminous coal and lignite production at the State level, and anthracite production, domestic imports of coal, and domestic and export demand at the national level. 
Energy System Described by Model: Short-term coal demand at the national level and supply at the national and State levels.

\section{Coverage:}

- Geographic: United States and 26 coal-producing States

- Time Unit/Frequency: Quarterly

- Product(s): Coal

- Economic Sector(s): International sector, coke plants, electric utilities, retail and general industries.

\section{Modeling Features:}

- Model Structure: Nine separate steps: seven steps for coal-consuming sectors and two for coal production.

- Modeling Technique: Ordinary least squares regressions.

- Special Features: SCOAL incorporates the primary economic, engineering, climatic, and institutional factors that are assumed to determine quarterly domestic coal market balances. Its inclusion of relative energy price information on both the supplyand demand sides makes it unique among short-term energy market models.

\section{Non-DOE Input Sources:}

- Bureau of Mines, Mineral Industry Yearbook

- Quarterly coal production (bituminous coal and lignite, and anthracite)

- Bureau of the Census, Monthly Report IM-145

- Monthly coal and coke imports

- Bureau of the Census, Monthly Report EM-522

- Coke industry: quarterly coke exports

- Foreign countries: quarterly steam coal and metallurgical coal exports

- Data Resources, Inc. (DRI) data base, data from Federal Reserve Board

- Other industries: industry activity indices

- Data Resources, Inc. (DRI) data base, data from National Weather Service

- Residential and commercial sectors: heating degree-days.

\section{DOE Data Input Sources:}

Forms and Publications:

- Energy Information Administration, Weekly Coal Report, DOE/EIA-0218, (Washington, DC)

- Quarterly coal production (bituminous coal and lignite, and anthracite)

- Energy Information Administration, Quarterly Coal Report, DOE/EIA-0121, (Washington, DC)

- Quarterly coal production (bituminous coal and lignite, and anthracite)

- Coke industry : consumption (quarterly) and stocks (at end of quarter); and quarterly coke production

- Other industries: steam coal consumption (quarterly) and stocks (at end of quarter)

- Energy Information Administration, Monthly Energy Review, DOE/EIA-0035, (Washington, DC)

- Foreign countries: prices

- Federal Energy Regulatory Commission, FERC Form 423, "Monthly Report of Cost and Quality of Fuels for Electric Plants"

- Fuel prices

- Energy Information Administration, Form EIA-3, "QuarterlyCoal Consumption Report - Manufacturing Plants"

- Other industries: steam coal consumption (quarterly) and stocks (at end of quarter)

- Energy Information Administration, Form EIA-5, "Coke Plant Report"

- Coke industry: consumption (quarterly) and stocks (at end of quarter); and quarterly coke production

- Energy Information Administration, Form EIA-6, "Coal Distribution Report"

- Other industries: steam coal consumption (quarterly)

- Residential and commercial sectors: quarterly coal consumption

- Energy Information Administration, Form EIA-7A, "Coal Production Report" 


\section{- Coal prices}

- Energy Information Administration, Form EIA-759, "Monthly Power Plant Report"

- Electric utilities: total quarterly coal consumption, coal stocks and quarterly generation

- Energy Information Administration, Form EIA-860, "Annual Electric Generator Report"

- Electric utilities: coal-based generating capacity

Models and Other:

- None.

General Output Descriptions: SCOAL is used by the Energy Information Administration's (EIA) Supply Analysis Branch (SAB) on a continuing basis to prepare projections of qu:rterly domestic coal market balances from the present 'over a six-to-eight-quarter horizon. EIA's coal producticn forecasts (national and State level) are developed using SCOAL. Forecasts of coal production at the national level appear in EIA's Short-Term Energy Outlook (STEO) and at the State level in the Quarterly Coal Report. SCOAL is also available to other parts of the U.S. Department of Energy, other agencies of the Federal Government, and to public and private institutions for analyses of short-term coal market behavior.

\section{Computing Environment:}

- Hard ware Used: IBM 3033 or $360 / 370$ (or equivalent)

- Operating System: OS/MVS2 MP

- Language/Software Used: Matrix Arithmetic Programming System (MAPS, Version 2) and Time Series Processor (TSP, Version 3.1)

- Memory Requirement: $1999 \mathrm{~Kb}$

- Storage Requirement: 40 Tracks

- Estimated Run Time: On an IBM 3084QX operating under MVS/XA, approximately $110 \mathrm{CPU}$ seconds to run all SCOAL programs once

- Special Features: None.

Independent Reviews Conducted: Compliance With EIA Model Documentation for Seven Models: William Wamsley and Margaret Harpine, June 15, 1983.

Status of Evaluation Efforts by Sponsor: Most recent craluation completed September 1984.

\section{Short-Term Integrated Forecasting System (STIFS)}

Description: STIFS is the system used to generate the forecasts of energy supply, demand and prices that are published in the Short-Term Energy Outlook. It consists of six interconnected submodels: refined petroleum products demand; refined petroleum products supply; electricity supply and demand; natural gas supply and demand; coal demand; petroleum and other energy prices.

Last Model Update: April 1991.

Part of Another Model? No.

Model Interfaces: Demand a.d price models from STIFS integrating model.

Sponsor:

- Office: Office of Energy Markets and End Use

- Division: Energy Markets and Contingency Information Division

- Branch: Short-Term Forecasting and Contingency Branch, EI-621

- Model Contact: David Costello

- Telephone: $202-586-1468$

Documentation: Energy Information Administration, 1993 Model Documentation Repon: Shon-Tern Integrated Forecasting System, DOE/EIA-M030 (Washington, DC).

Archive Media and Installation Manual(s):

- STIFSF82 - archived for the Shon-Tem Energy Outlook (STEO) February 1982.

- STIFSA82 - STEO August 1982

- $\quad$ STIFSF83 - STEO February 1983

- $\quad$ STIFSA83 - STEO August 1983

- STIFSF84 - STEO February 1984

- STIFSA84 - STEO August 1984

- STIFS185 - STEO January 1985

- STIFS785 - STEO July 1985

- STIFS186 - STEO January 1986

- STIFS786 - STEO July 1986

- STIFS187 - STEO January 1987 
- $\quad$ STIFS787 - STEO July 1987

- $\quad$ STIFS188 - STEO January 1988

- STIFS788 - STEO July 1988

- $\quad$ STIFS189 - STEO January 1989

- STIFS190 - STEO January 1990

- $\quad$ STIFS990 - STEO September 1990

- STIFS191 - STEO January 1991

- STIFS791 - STEO September 1991

- STIFS192 - STEO January 1992

- $\quad$ STIFS1092 - STEO September 1992

- STIFS193 - STEO January 1993.

Purpose: STIFS generates short-term (up to 8 quarters), monthly forecasts of U.S. supplies, demands, imports, exports, and stocks of various forms of energy. The models that constitute STIFS generate forecasts for various weather, price and macroeconomic scenarios.

Energy System Described by Model: U.S. energy production, consumption, imports, exports, stocks, and prices.

Coverage:

- Geographic: National

- Time Unit/Frequency: Monthly published results show only quarterly statistics plus forecasts for up to 2 years

- Product(s): Motor gasoline, distillate fuel oil, residual fuel oil, jet fuel, liquefied petroleum gases, other petroleum products, natural gas, coal, electricity, nuclear energy, hydroelectricity and gross and net energy consumption

- Economic Sector(s): Total United States, with explicit treatment given to electric utility and nonutility consumption, imports, and exports.

Modeling Features:

- Model Structure: Accounting and algorithmic to balance supply and demand

- Modeling Technique: Includes accounting, algorithmic, econometric, and time trending techniques

- Special Features: STIFS is updated every quarter to produce new demand forecasts for the Shor-Term Energy Outlook.

\section{Non-DOE Input Sources:}

- U.S. Department of Transportation, Federal Highway Administration, Highway Statistics Division, Traffic Volume Trends (monthly)

- Vehicle miles traveled

- Form 41 Data Base, collected by I.P. Sharp for U.S. Department of Transportation

- Revenue ton-miles

- Aircraft yield

- Aircraft load factor

- Available ton-miles

- Average aircraft efficiency

- Bureau of the Census X-11 program Seasonal adjustments

- Vehicle miles traveled

- Retail price--motor gasoline, distillate fuel oil, residual fuel oil

- Product supplied--total motor gasoline, No. 2 diesel fuel, liquefied petroleum gases (excluding ethane), kerosene-type jet fuel, petrochemical feedstocks

- Price of diesel fuel oil

- Price of natural gas--to industrial users and to electric utilities

- Wholesale prices--heating oil, motor gasoline

- Revenue ton-miles

- Aircraft yield

- Average aircraft efficiency

- Demand for ethane

- Price of residual fuel to electric utilities

- Residential and commercial natural gas prices

- Residential electricity price

- Price of coal to electric utilities

- Ǔ.S. Depariment of Labor, Bureau of Labor Statistics, Consumer Price Index--Detailed Report 
- Retail price of motor gasoline

- Consumer price index

- U.S. Department of Labor, Bureau of Labor Statistics

- Producer price index

- U.S. Department of Labor, Bureau of Labor Statistics Producer Price Index (monthly issues)

- Producer price index for petroleum products

- Data Resources, Inc., U.S. Central Data Base

- Consumer price index projections

- Disposable personal income projections

- Industrial production, index, projections

- Chemical production index, projections

- Change in manufacturing, inventories, projections

- Raw steel production, projections

- AA bond rating for utilities, projections

- DRI - McGraw-Hill

- Real exchange rate plus projections

- AA bond rating for utilities plus projections

- U.S. Department of Commerce, Bureau of Economic Analysis, National Income and Product Accounts of the United States, Table 2.2

- Disposable personal income

- U.S. Department of Commerce, Bureau of Economic Analysis, Survey of Current Business

- Gross national product

- U.S. Department of Commerce, Bureau of Economic Analysis

- Private domestic investument

- Change in manufacturing inventories

- U.S. Department of Commerce, National Oceanic and Atmospheric Administration, Monthly State, Regional and National Heating Degree-Days Weighted by Populaiion

- New England heating degree-days
- Mid Atlantic heating degree-days

- Population-weighted heating and cooling degree days

- U.S. Federal Reserve System, Board of Governors, Statistical Release G 12.3

- Industrial production index (historical)

- Chemical production index (historical)

- Change in manufacturing inventories (historical)

- American Gas Association, Quarterly Repont of Gas Industry Operations

- Number of customers, residential and commercial

- American Iron and Steel Institute, Raw Steel and Pig Iron Production Repons, AIS-7 (monthly reports)

- Raw steel production (historical)

- Merrill Lynch Bond Pricing Survey

- AA bond rating for utilities.

\section{DOE Data Input Sources:}

Forms and Publications:

- Energy Information Administration, Costs and Indices for Domestic Oil and Gas Field Equipment and Production and Production Operations 1985 (Washington, DC)

- Total number of wells drilled

- Amount of drilling expenditures

- Hole production factor

- Number of drilling permits

- Number of seismic crews working

- Energy Information Administration, Weekly Petroleum Status Repon, DOE/EIA-0208 (Washington, DC)

- Retail price of motor gasoline

- Energy Information Administration, Monthly Energy Review; DOE/EIA-0035 (Washington, DC)

- Retail prices--motor gasoline, distillate and residual fuel oil 
- Product supplied--total motor gasoline, No. 2 fuel oil (industrial sector), nonutility distillate and residual fuel oil

- Price of natural gas--for industrial users and to electric utilities

- Electricity generation--total, nuclear, hydroelectric, petroleum, natural gas, coal)

- Price of residual fuel to electric utilities

- Natural gas delivered--to residential and commercial consumers

- Natural gas used by pipelines

- Coal consumption--at electric utilities and by industrial users

- Price of imported crude oil

- Domestic and composite refiner acquisition cost of crude oil

- Natural gas wellhead price

- Residential and commercial natural gas prices

- Price of coal to electric utilities

- Last quarter's active rig count

- Energy Information Administration, Petroleum Supply Monthly, DOE/EIA-0109 (Washington, DC)

- Field production--crude oil, pentanes plus, LPGs, other hydrocarbons and alcohol

- Refinery output--motor gasoline, distillate, residual, jet fuel, LPGs, unfinished oils, other petroleum, pentanes plus

- Net imports--crude oil, motor gasoline, distillate, residual jet fuel, LPGs, unfinished oils, other petroleum, pentanes plus

- Refinery inputs--crude oil, unfinished oils, pentanes plus, LPGs, other petroleum, aviation gasoline blending components

- Product supplied--total petroleum, motor gasoline, distillate, residual, jet fuel, LPGs, other petroleum, crude oil, unleaded motor gasoline, petrochemical feedstocks, miscellaneous products, crude oil and pentanes plus

- Demand for ethane
- Closing stocks--crude oil, motor gasoline, distillate, residual, jet fuel, LPGs, other petroleum, motor gasoline blending components, unfinished oils, pentanes plus

- Crude oil losses

- Inputs to crude oil distillation units

- Refinery utilization

- Unaccounted for crude oil

- Refinery processing gain

- Energy Information Administration, Petroleum Marketing Monthly, DOE/EIA-0380 (Washington, DC)

- Imported price of crude oil, kerosene based jet fuel, wholesale motor gasoline, residential distillate

- Product supplied--No. 2 diesel fuel, No. 2 fuel oil (industrial sector)

- Price of diesel fuel oil

- Wholesale prices--heating oil, motor gasoline

- Average retail price for kerosene jet fuel

- Energy Information Administration, Monthly Energy Review, DOE/EIA-0035 (Washington, DC)

- Price of natural gas to electric utilities

- Price of residual oil to electric utilities

- Nonutility supply of electricity

- Net imports of electricity

- Heat content of natural gas--marketed (wet) production, dry production, electric utility consumption

- Heat content of coal--electric utility consumption

- Heat content of petroleum products--pentanes plus, LPGs, residual fuel oil, distillate fuel oil

- Heat rate (Btu per kilowatthour)--coal, natural gas, residual fuel oil, distillate fuel oil

- Energy Information Administration, Natural Gas Monthly, DOE/EIA-0130 (Washington, DC)

- Wet gas production, dry gas production, imports, exports, supplemental gaseous fuels, injections to and withdrawals from working gas storage, total 
natural gas consumption, unaccounted for natural gas

- Energy Information Administration, Quarterly Coal Report, DOE/EIA-0121 (Washington, DC)

- Total consumption, production, imports, exports, primary stock change, secondary stock levels

- Coke production and consumption, and end-ofmonth coke stocks (January 1981 through December 1981)

- Coking coal demand

- Coal consumption--by industrial users, residential and commercial and total retail and general industry

- Coal production

- Net imports of coal

- Coal exports

- Energy Information Administration, Form EIA-861, "Annual Electric Generator Report"

- Coal-fired generating capacity

- Federal Energy Regulatory Commission, FERC Form 432, "Monthly Report of Cost and Quality of Fuels for Electric Plants"

- Prices to electric utilities--natural gas, residual fuel, coal

- Energy Information Administration, Coke and Coal Chemicals, DOE/EIA-0120 (Washington, DC, monthly issues)

- Coke production and consumption, and end-ofmonth coke stocks (December 1977 through December 1980)

- Energy Information Administration, Electric Power Monthly, DOE/EIA-0226 (Washington, DC)

- Generation of electricity from coal, natural gas, residual fuel oil, distillate fuel oil

- Total electricity generation

- Total electricity sales

- Net imports of electricity

- Consumption of fuels at electric utilities
- Residential electricity price

Models and Other:

- Energy Information Administration, Dallas Field Office

- Crude oil production

- Dry gas production

- Energy Information Administration, Office of Oil and Gas

- Net imports of gas

- Energy Information Administration, Office of Energy Markets and End Use

- Consumption and price projections

- Energy Information Administration, Office of Coal, Nuclear, Electric and Alternate Fuels

- Coal production and electricity generation by nuclear power and hydroelectric power

General Output Descriptions: STIFS is used to generate short-term (up to 8 quarters), monthly forecasts of U.S. supplies, demands, imports, exports, and stocks of various forms of energy.

\section{Computing Environment:}

- Hazdware Used: IBM 3084

- Operating System: OS/MVS2

- Language/Software Used: SAS, Version 6.07

- Memory Requirement: $2000 \mathrm{~Kb}$

- Storage Requirement: 3380 disk -- Approximately 900 tracks to reload the files contained on the distribution tape, and a minimum of approximately 2000 tracks to store and execute the entire system.

- Estimated Run Time: On an IBM 3084QX operating under MVS/XA, 120 CPU seconds

- Special Features: None.

Independent Reviews Conducted: Independent Expert Reviews conducted by G.S. Maddala and T. Mount, June 1991.

Status of Evaluation Efforts by Sponsor: None. 


\section{Short-Term Nuclear Annual Power Production Simulation (SNAPPS)}

Description: SNAPPS forecasts the short-term monthly and annual electric power generation by U.S. commercial nuclear power plants. SNAPPS is a relatively simple, straightforward accounting model programmed in FORTRAN. The model consists of codes that provides accounting for each nuclear reactor's generation for the projection period.

Last Model Update: March 1991.

Part of Another Model? No.

Model Interfaces: The Nuclear Waste Fee System (NWFEE) - calculates nuclear waste fund revenues. The STEO Trialog - a microcomputer system component that is used as a tool for sensitivity analysis and documentation of short-term energy outlook data downloaded from SNAPPS mainframe output.

\section{Sponsor:}

- Office: Office of Coal, Nuclear, Electric and Alternate Fuels

- Division: Analysis and Systems Division

- Branch: Supply Analysis Branch, EI-532

- Model Contact: Kenneth Chuck Wade

- Telephone: 202-254-5514

\section{Documentation:}

- Shon-Term Nuclear Annual Power Production Simulation Documentation, Version 4, Science Applications International Corporation, June 1990.

- Short-Term Nuclear Annual Power Production Simulation Documentation, System Sciences, Inc., November 1984, and Addendum, September 1986.

- SNAPPS - Short-Term Nuclear Annual Power Production Simulation, ORNL, CET-001/SNAPPS, August 1981.

Archive Media and Installation Manual(s):

- SNAPP893-Archived for the Short-Term Energy Outlook, July 1989

- $\quad$ SNAP9103 - Archived for the Short-Term Energy Outlook, January 1991

- SNAP92Q4 - Archived for the Shor-Term Energy Outlook, 4ih Quarier 1992
- SNAP93Q1 - Archived for the Shor-Tern Energy Outlook, 1st Quarter.

Purpose: SNAPPS forecasts short-term monthly and annual generation of electricity by nuclear reactors in the United States.

Energy System Described by Model: Short-term electricity generation of domestic, commercial nuclear reactors.

\section{Coverage:}

- Geographic: Total United States, individual States, individual reactors, 10 Federal regions, or 4 Census regions

- Time Unit/Frequency: 18-month forecasts quarterly; 5 -year forecasts annually, up to 10 years

- Product(s): Projections of electricity generation from nuclear power plants

- Economic Sector(s): Electric utilities which own or operate nuclear power plants.

Modeling Features:

- Model Structure: The model consists of codes which provides accounting for each nuclear reactor's generation over the projection period.

- Modeling Technique: The model develops reactor activity schedules, determining if the reactor is generating power or is in extended shutdown. Individual reactor monthly generation is computed by multiplying the designated capacity (net or gross) times the appropriate capacity factor times the hours the reactor operates in that month. For the near term, about 6 months, the values are calculated in a preprocessor that estimates system-wide monthly capacity factors by applying time-series techniques to historical data. The relationship between the monthly capacity factor and the percent of capacity on-line is modeled by a BoxJenkins transfer function. For the remainder of the projection period, SNAPPS uses average, full-cycle capacity factors, which are functions of reactor type (BWR or PWR) and fuel cycle (1st, 2nd, or equilibrium). The resulting reactor generation values are then cumulated into monthly, annual and regional totals. The model contains the option of using positive refueling times in lieu of seasonality factors.

- Special Features:

- Allows the user to project either gross or net electricity generation

- Reports aggregate operating capacity factors 
- May be run either in a reactor-specific or an aggregate mode.

\section{Non-DOE Input Sources:}

- Nuclear Regulatory Commission, NRC Operations Center Plant Status Report (updated weekly)

- Scheduled outage data (start date and duration)

- Nuclear Regulatory Commission, Operating Data Reports

- Historical generation data (reactor name, date, historical generation and type of generation)

- David Andress, Washington Consulting Group, Analysis of Capacity Factors, March 1990

- Cycle-specific data (cycle capacity factor)

- Generic parameters (monthly capacity factor adjustment (seasonality) factors)

- David Andress, System Sciences, A nalysis of Capacity Factors, September 1984

- Cycle-specific data (cycle capacity factor)

- Generic parameters (monthly capacity factor adjustment (seasonality) factors).

\section{DOE Data Input Sources:}

\section{Forms and Publications:}

- Energy Information Administration, Form EIA-759, "Monthly Power Plant Report"

- Historical generation data (1986 on: reactor name, date, historical generation and type of generation)

- Office of Civilian Radioactive Waste Management, Form RW-859, "Nuclear Fuel Data"

- Cycle-specific data (cycle number, cycle start date, cycle generation time, cycle capacity factor, cycle full power days, refueling start date and refueling time)

- Energy Information Administration, Form EIA-860, "Annual Electric Generator Report"

- Basic reactor characteristics (reactor capacities)

Models and Other:
- Energy Information Administration, International Nuclear Model, (INM) maintained by the Office of Coal, Nuclear, Electric and Alternate Fuels

- Basic reactor characteristics (reactor type, reactor name, reactor capacities, DOE region, start dates (initial criticality, first electricity and commercial operation), State code and reactor retirement date)

- Energy Information Administration, Office of Coal, Nuclear, Electric and Alternate Fuels

- Generic parameters

- Default capacity factor

- Default full power days

- Default refueling time

- Monthly capacity factor adjustment (seasonality) factors

- Annual capacity factor adjustment (trend) factors.

\section{General Output Descriptions:}

- Monthly, quarterly and annual forecasts of the total electricity generated by the Nation's reactors

- Monthly and annual forecasts of electricity generated by each reactor

- Monthly and annual forecasts of aggregate operating capacity factors

- Reactor operating characteristics.

Computing Environment:

- Hardware Used: IBM 3084QX

- Operating System: MVS/XA

- Language/Software Used: VS FORTRAN (Uses the G-1 compiler)

- Memory Requirement: $1600 \mathrm{~Kb}$

- Storage Requirement: 3380 disk--5 Mb for model and data

- Estimated Run Time: 7 CPU seconds

- Special Features: None.

Independent Reviews Conducted: 
- Independent Expert Review of Short-Term Nuclear Annual Power Production Simulation Model (SNAPPS), John L. Solow, Department of Economics, College of Business Administration, University of Iowa, Iowa City, IA 52242, May 1990.

- Model Quality Audit by the Office of Statistical Standards, June 1990.

Status of Evaluation Efforts by Sponsor: None.

\section{Transportation Energy Demand Model (TED)}

Description: TED is designed to project transportation energy demand at the national and Census region level, by fuel and by year to 2010. TED provides the transportation demand forecasts used in the AEO modeling system. The model consists of four distinct segments: personal highway travel, freight travel, aviation travel, and other transportation. These segments consist of data estimates and assumptions necessary to execute various specific forecasting equations of the model.

Last Model Update: September 1990.

Part of Another Model? Part of the Intermediate Future Forecasting System (IFFS).

Model Interfaces: From the Intermediate Future Forecasting System: real GNP, real industrial output by economic sector, GNP price deflator, consumer price index, real exports, real imports, real fuel prices, world oil price calibration factors, and regional disposable personal income. To the Intermediate Future Forecasting System, fuel demand by Census region.

\section{Sponsor:}

- Office: Office of Integrated Analysis and Forecasting

- Division: Demand and Integration Division

- Branch: Demand Analysis and Forecasting Branch, EI-813

- Model Contact: David Chien

- Telephone: 202-586-3994

Documentation: Energy Information Administration, $P C$ AEO Forecasting Model for the Annual Energy Outlook 1991, Model Docunzentation (Section 4, Transportation Energy Demand), DOE/EIA-M036(90) (Washington, DC, March 1990) and Technical Notes.

Archive Media and Installation Manual(s): Archived as part of IFFS93.
Purpose: To provide long-term projections of transportation energy consumption for the Annual Energy Outlook.

Energy System Described by Model: Demand for major fuels by the transportation sector (as defined in the State Energy Data System).

\section{Coverage:}

- Geographic: Census region (for totals of each fuel across sectors) and United States (for fuel use, travel, etc., by sector)

- Time Unit/Frequency: Annual

- Product(s): motor gasoline, aviation gasoline, diesel/distillate, residual oil, electricity, jet fuel, LPG, lubricants, pipeline, alcohol, compressed natural gas

- Economic Sector(s): Forecasts are produced for personal travel, freight trucks, railroads, domestic marine, international marine, aviation, and military use.

Modeling Features:

- Model Structure: Recursive, requiring no equation solver as such

- Modeling Technique: Econometrics (for passenger travel, aviation, and lubricants), exogenous engineering and judgment (mpg and various freight characteristics), and structural for the explicit personal vehicle capital stock.

- Special Features: None.

Non-DOE Input Sources:

- Bureau of the Census

- Population

- Bureau of Economic Analysis

- Personal disposable income

- Argonne National Laboratory (ANL) freight model

- Truck diesel share

- Average truck MPG

- Truck vehicle-miles traveled

- Rail ton-miles traveled

- Federal Aviation Administration, FAA Aviation Forecasts, Fiscal Years 1989-2000, FAA-APO-89-1, February 1989 
- Jet load factor

- Private plane use

- Department of Defense

- Military aircraft use.

\section{DOE Data Input Sources:}

Forms and Publications:

- Energy Information Administration, Short-Term Energy Outlook, DOE/EIA-0202, Washington, D.C., (quarterly)

- Benchmark levels (1986-1992)

Models and Other:

- Energy Information Administration, Annual Energy Outlook 1992 Forecasting System

- Benchmark parameters (benchmark switch, benchmark levels (1986-1992) and benchmark factors)

- Personal disposable income

- Fuel prices

- $\quad$ Real U.S. GNP

- GNP price deflator

- Industrial output

- World oil price

- Consumer Price Index

- Real exports and imports

- Pipeline natural gas consumption

- Energy Information Administration, Mini-Macroeconomic Personal Computer (PCMAC) Model

- Industrial output

- Energy Information Administration, Oil and Gas Spreadsheet (OGS-PC)

- Pipeline ratural gas consumption.

General Ouiput Descriptions: TED produces reports on fuel use, indices and average efficiencies.

Computing Environment:
- Hardware Used: IBM 3084QX

- Operating System: MVS/XA

- Language/Software Used: FORTRAN 77

- Memory Requirement: $300 \mathrm{~Kb}$

- Storage Requirement: 140 tracks of an IBM 3380 disk pack

- Estimated Run Time: 5 minutes on an IBM 3084QX

- Special Features: None.

Independent Reviews Conducted: Independent Expert Review conducted by Edward Leamer, June 1988.

Status of Evination Efforts by Sponsor: None.

\section{Urarilum Market Model (UMM-PC)}

Description: UMM-PC projects prices, production, imports, inventory, capital expenditures, and employment in the uranium mining and milling industry. The model considers every major production center and utility on a worldwide basis (with centrally planned economies considered in a limited way).

Last Model Update: October 1992.

Part of Another Model? None.

Model Interfaces: None.

Sponsor:

- Office: Office of Coal, Nuclear, Electric and Alternate Fuels

- Division: Analysis and Systems Division

- Branch: ¿̇nergy Resources Assessment Branch, EI532

- Model Contact: Ercan Tukenmez

- Telephone: 202-254-5544

Documentation: Energy Information Administration, Documentation of the Uranium Market Model (UMM-PC), DOĖ/OR-21400-H 11 (Washington, DC, January 1993).

Archive Media and Installation Manual(s):

- $\quad$ ORUMMPC - for the 1987 Viability Study.

- ORUMM89 - Archived for Domestic Uranium Mining and Milling Industry 1988: Viability A ssessment 
- ORUMM90 - Archived for Domestic Uranium Mining and Milling Industry 1989: Viability A ssessment

- ORUMM91 - Archived for the Domestic Uranium Mining and Milling Industry 1990: Viability Assessment

- ORUMM92 - Archived for the report, Domestic Uranium Mining and Industry 1991.

Purpose: The UMM-PC is used to model international uranium mining, milling, and marketing activitics.

Energy System Descriled by Model: International uranium mining and milling.

\section{Coverage:}

- Geographic: World

- Time Unit/Frequency: Annually

- Product(s): Natural uranium

- Fconomic Sector(s): Buyer and producer regions.

Modeling Features:

- Model Structure: Uranium supplied by the mining and milling industry is matched to the demand for uranium by electric utilities possessing nuclear power plants. Equations are listed in Chapter II, "Technical Specifications," of the Model Documentation Report.

- Modeling Technique: Microeconomic simulation model

- Special Features: Nonc.

Non-DOE Input Sources:

- Fuel-Trac Report on Reyuirements and Commitment Status for U238 for Country and Country Group, Nuclear Assurance Corporation (NAC), February 1991

- Country nane

- Country II) number

- Utility ID number

- Country production

- Net imports

- Pirst year of import quota

- I tility name

- Inventorics
- Inventory to satisfy inventory demand

- Inventory available for sale

- Import quota

- Detailed U308 Commitment Status by Supplier, Nuclear Assurance Corporation (NAC), February 1991

- Production center ID

- Unmet domestic demand

- Production committed to this utility in a simulation year

- Production center name

- Pointer to country of production center

- Year when production starts

- Initial production start year

- Size of operation

- Production amount available for sale

- Year in which production was sold

- Country committed to sell to

- Estimates of Behavior, Management and Market Data, Nuclear Resources International, February 1984, for ORNL

- Years of desired uranium inventory.

DOE Data Input Sources:

\section{Forms and Publications:}

- Energy Information Administration, Form EIA-858, "Uranium Industry Annual Survey"

- Inventories

- Energy Information Administration, Domestic Uranium Mining and Milling Industry 1989 Viabulity A ssessment, Appendix E, December 1990, DOE/EIA-0477, (Washington, DC).

- Spot price

- Contract price

- imployment

- Capital expenditures 
- Acceptable selling price

Models and Other:

- None.

General Output Descriptions:

- World spot price

- Domestic or region-specific spot prices

- World contract price

- Domestic or region-specific contract prices

- Production from every major production center in the world

- Production on a country- or region-specific basis

- Net imports into each region

- Utilities' inventories, tabulated from inventories of individual utility groups on a worldwide basis

- Annual drawdown of utilities' inventories

- Capital expenditures by the mining and milling industry

- Employment in the mining and milling industry.

Computing Environment:

- Hardware Used: IBM-compatible personal computer

- Operating System: MS-DOS Version 2.0 or greater

- Language/Software Used: Pascal (compiled \& linked using Borland Turbo Pascal 4.0)

- Memory Requirement: $640 \mathrm{~Kb}$

- Storage Requirement: $630 \mathrm{~Kb}$

- Estimated Run Time: On a Compaq Deskpro 386/40 operating at $16 \mathrm{MHz}$ under DOS 3.2 with an Intel 80287 coprocessor, between 8 and 9 seconds

- Special Features: Model requires a math coprocessor and a hard disk plus a version of DOS that is 2.1 or greater.

Independent Reviews Conducted: None.

Status of Evaluation Efforts by Sponsor: None.

\section{Wellhead Gas Productive Capacity Model (GASCAP)}

Description: GASCAP estimates the historical wellhead productive capacity of natural gas for the lower 48 States and projects the productive capacity for 2 years. The ShortTerm Energy Outlook (STEO) output for low, base and high cases is used to estimate the number of active rigs and oil and gas well completions. The projected oil production is used to estimate the oil-well gas production (which is assumed to be producing at capacity) using a constant gas-oil ratio. The gas demand is also taken from STEO. The difference between demand and oil-well gas production is assumed to be the gas-well gas demand and the production as long as capacity exceeds demand.

Last Model Update: September 1992.

Part of Another Model? No.

Model Interfaces: GASCAP projections are based on the gas demand projected by $S T E O$.

Sponsor:

- Office: Oil and Gas

- Division: Reserves and Natural Gas

- Branch: Reserves and Production, EI-443

- Model Contact: James N. Hicks

- Telephone: 214-767-2200

Documentation: Energy Information Administration, Model Documentation for the Wellhead Gas Productive Capacity Model (Washington, DC, May 1993).

Archive Media and Installation Manual(s): GASCAP92 Archived for the Natural Gas Productive Capacity for the Lower 48 States: 1982 through 1993.

Purpose: GASCAP is used to project the natural gas wellhead productive capacity for the lower 48 States. It also allows quantification of the available productive capacity and the projected capacity under differing future scenarios.

Energy System Described by Model: GASCAP measures and predicts wellhead natural gas productive capacity.

\section{Coverage:}

- Geographic: 10 area/State subdivision of the lower 48 States 
- Time Unit/Frequency: Projects 2 years for each subdivision and is summed for the lower 48 States under varying scenarios.

- Product(s): Natural gas

- Economic Sector(s): lower 48 States and subdivisions.

\section{Modeling Features:}

- Model Structure: The model consists of a series of statistical analysis system (SAS) procedures utilizing a modified rate of production versus cumulative production (Rate-cum) equation. It also consists of a series of Lotus 1-2-3 spreadsheets that interlock with mainframe outputs.

- Modeling Technique: Peak production rates and cumulative production were determined for wells that first had production in a vintage year for that year and each successive year, i.e., peak rates and cumulative production were determined for 1978, 1979...1991 for wells that first had production in 1978; 1979, $1980 . . .1991$ for wells that first had production in 1979; etc.

- Special Features: Several Personal Computer (PC) spreadsheet programs are used to assimilate the demand and well completion data that are input for the projection programs in GASCAP. Different scenarios can be analyzed by changing the assumed input parameters; e.g., oil production, active rigs, gas demand, etc.

\section{Non-DOE Input Sources:}

- Dwight's Energy Data, Inc., well history tapes, Richardson, TX, 1991

- Monthly natural gas production by well

- Cumulative production to date by month

- Baker Hughes, Incorporated

- Monthly rotary rig counts

- Energy Information Administration computations based on well reports submitted to the American Petroleum Institute by the Petroleum Information Corporation

- Oil and gas wells drilled.

\section{DOE Data Input Sources:}

- Energy Information Administration, Natural Gas Annual, DOE/EIA-0131 (Washington, DC, annual)
- Marketed wet natural gas production by State

- Gross gas production by State

- Oil well gas production by State

- Energy Information Administration, Natural Gas Monthly, DOE/EIA-0130 (Washington, DC, January 1982 through December 1992)

- State marketed gas production

- Energy Information Administration, Monthly Energy Review, DOE/EIA-0035 (Washington, DC, monthly)

- Crude oil production

- World oil price (imported refiner acquisition cost)

- Marketed gas production

- Natural gas wellhead price

- Energy Information Administration, Short-Term Energy Outlook, DOE/EIA-0202 (Washington, DC, quarterly)

- Marketed dry natural gas demand for low, base, and higher case.

General Output Descriptions: GASCAP produces wellhead production and capacity estinates for each subdivision and for each case submitted.

\section{Computing Environment:}

- Hardware Used: IBM 3084QX and IBM PC Compatible

- Operating System: MVS/XA and DOS

- Language/Software Used: FORTRAN/SAS/COBOL; Lotus 1-2-3, Version 2.2; Harvard Graphics, Version 2.3; WordPerfect, Version 5.1

- Memory Requirement: $1200 \mathrm{~Kb}$ mainframe and $2 \mathrm{Mb}$ for $\mathrm{PC}$

- Storage Reçuirement: $7 \mathrm{Mb}$ hardrive; on PC 2,000 Kb

- Estimated Run Time: $6 \mathrm{CPU}$ minutes time

- Special Features: None.

Independent Reviews Conducted: None.

Status of Evaluation Efforts by Sponsor: None. 


\section{World Energy Projection System (WEPS-PC)}

Description: WEPS-PC is an integrated set of microcomputer-based spreadsheets containing data compilations, assumption specifications, descriptive analysis procedures, and projection models. WEPS-PC provides projections of total world primary energy consumption disaggregated by 10 individual countries and 10 country groupings; projections of energy consumption by primary energy type and by economic sector for selected countries; projections of natural gas production; and projections concerning world oil supplies for use in the Oil Market Simulation Model (OMS). For both historical series and projection series, WEPS-PC provides analytical computations of percentages of energy consumption attributable to each primary energy source, total energy consumption per dollar of gross domestic product (GDP), and an energy/GDP index. WEPS-PC projections and analyses are published annually in the Intemational Energy Outlook (IEO) and are used in various internal EIA studies.

Last Model Update: January 1992.

Part of Another Model? No.

Model Interfaces: Provides inputs to the Oil Market Simulation (OMS) model. Accepts or considers outputs from the World Integrated Nuclear Evaluation System (WINES) and the International Coal Trade Model (ICTM'.

Sponsor:

- Office: Office of Integrated Analysis and Forecasting

- Division: Energy Demand and Integration Division

- Branch: International, Economic and Integrated Forecasting Branch, EI-812

- Model Contact: A. David Sandoval

- Telephone: 202-586-6581

Documentation: Energy Information Administration, World Energy Projection System Model Documentation (Washingion, DC., June 1992).

Archive Media and Installation Manual(s):

- WEPS92- World Energy Projection System 1992 for the Intemational Energy Outlook 1992 and the Annual Energy Outlook 1992

- WEPS93 - World Energy Projection Sysiem 1993 for the Intemational Energy Outlook 1993.

Purpose: WEPS-PC projects total primary energy consumption, energy consumption by primary energy source, net electricity consumption, consumption of primary en- ergy and electricity by major end user categories, OPEC oil production capacity, non-OPEC oil production, and natural gas production. WEPS-PC provides an accounting framework that produces consistent world energy consumption balances from diverse sources of information.

Energy System Described by Model: Oil, gas, coal, nuclear, other (hydro and geothermal), and electricity.

\section{Coverage:}

- Geographic: World by selected countries and major country groups

- Time Unit/Frequency: Projections of production by year and of consumption by 5 -year intervals through the year 2010

- Product(s): Units include million barrels per day (oil), trillion cubic feet (gas), million short tons (coal), billion kilowatthours (nuclear), and quadrillion Btu (Other and electricity)

- Economic Sector(s): Industry, transportation, residential/commercial, and electric utilities.

\section{Modeling Features:}

- Model Structure: The model structure is an accounting framework of relationships concerning energy consumption and production, economic growth, conservation and efficiency gains, production capacities, available reserves, and recoverable resources that are extended to the year 2010 considering historical trends, planned construction, model projections, and other related assumptions.

- Modeling Technique: The major technique used in the WEPS-PC accounting framework is to project total energy consumption by region based on an assumed relationship to economic growth as measured by gross domestic product (GDP). Prujections of all other energy sources are madue consistent with projected total energy and subject to estimates of available resources. Econometric techniques are not used to determine changes in relationships over the projection period.

- Special Features: None.

\section{Non-DOE Input Sources:}

- Charles D. Masters, et al., U.S. Geological Survey, World Resources of Crude Oil and Natural Gas, Proceedings from 13ti. World Petroleum Congress, 1991

- Undiscovered natural gas resources

- Remaining oil resources 
- International Energy Agency (Paris), Coal Information

- Adjustment factor to electric generation efficiency

- International Energy Agency, World Energy Statistics and Balances

- Total electricity consumption

- Amount of energy source (oil, gas, coal, nuclear, other) used for electricity generation

- Amount of energy source (oil, gas, coal) used for all -purposes other than electricity generation

- International Energy Agency (Paris), Energy Balances of OECD Countries

- Consumption of energy source (oil, gas, coal, nuclear, other) by sector

- PennWell Publishing Co., Oil and Gias Joumal

- Proved reserves for oil and natural gas

- Reed Business Publishing, Intemational Water Power and Dam Construction

- Hydropower construction plans

- United Nations, Energy Statistics Yearbook

- Hydro and geothermal capacity utilization rates

- The WEFA Group, World Economic Oullook

- Gross domestic product annual growth rate

- The WEFA Group, World Economic Service Historical Data

- Gross domestic product

- Gross domestic product annual growth rate.

DOE Data Input Sources:

- Energy Information Administration, Annual Energy Outlook (Washington, DC, Annually)

- Consumption of energy source (oil, gas, coal, nuclear, other) by sector (industry, transportation, residential/ commercial, electric utility)

- Energy Information Administration, World Nuclear Capacity and Fuel Cycle Requirements 1992

- Nuclear power gencrating capacity
- Percentages of nuclear power generating capacity utilized

- Energy Information Administration, Intemational Energy Annual (Washington, DC, Annually)

- Oil consumption in standard units

- Nuclear energy consumption in standard units

- Natural gas consumption in standard units

- Coal consumption in standard units

- Other energy consumption

- Standard unit (Quadrillion Btu) conversion factor for energy source (oil, gas, coal, nuclear)

- Nuclear power imported or (negative value) exported

- Natural gas production

- Total consumption of electricity

- Ratio of total electricity consumed to total inputs of all energy sources required to generate total electricity consumed

- Energy Information Administration, Intemational Oil and Gas Exploration and Development Activities

- Natural gas opening reserves.

General Output Descriptions: Primary energy and end-use energy consumption by speçific energy source (oil, natural gas, coal, nuclear, other, and electricity), natural gas production, oil production, and oil capacity by country or country group and specified years.

\section{Computing Environment:}

- Hardware Used: IBM compatible personal computer.

- Operating System: DOS, Version 4.0

- Language/Software Used: Lotus 1-2-3, Version 2.2

- Memory Requirement: The world energy consumption spreadsheet programs require about $2.3 \mathrm{Mb}$ of hard disk memory. To run the world energy consumption basecase spreadsheet requires about $580 \mathrm{~Kb}$ of RAM; the natural gas production spreadsheet about $150 \mathrm{~Kb}$ of RAM; the OECD sector spreadsheet about $75 \mathrm{~Kb}$ of RAM; and the elcctricity consumption spreadsheet about $250 \mathrm{~Kb}$ of RAM.

- $\quad$ Storage Requirement: $2.3 \mathrm{Mb}$ 
- Estimated Run Time: Given the incorporation of base case assumptions, world energy consumption spreadsheet programs solve in about 5 seconds. The process of generating associated range values requires from 5 to 10 minutes of user time.

- Special Features: None.

Independent Reviews Conducted: None.

Status of Evaluation Efforts by Sponsor: No evaluation currently being undertaken

\section{World Integrated Nuclear Evalua- tion System (WINES-PC)}

Description: The World Integrated Nuclear Evaluation System (WINES-PC) is an aggregate demand-based partial equilibrium model used by the Energy Information Administration (EIA) to project long-term domestic and international nuclear energy requirements. WINES-PC follows a top-down approach in which economic growth rates, delivered energy demand growth rates, and electricity demand are projected successively to ultimately forecast total nuclear generation and nuclear demand capacity. WINES-PC could potentially be used to produce forecasts for any country or region in the world. Presently, WINESPC is being used to generate long-term forecasts for the United States and for all countries with commercial nuclear programs in the world, excluding countries located in centrally planned economic areas. Projection for the United States are developed for the period from 2010 through 2030, and for other countries for other countries for the period starting in 2000 or 2005 (depending on the country) through 2010.

WINES-PC serves as a flexible tool with which to assist the U.S. Department of Energy (DOE) program offices and other Government agencies in their analyses of long-term nuclear energy demand and supply, and to support cooperative efforts between the United States and the Nuclear Energy Agency (NEA) of the Organization for Economic Cooperation and Development (OECD), the International Energy Agency (IEA), and the International Atomic Energy Agency (IAEA). WINES-PC is used to develop longterm projections of nuclear capacity and generation published annually by EIA in Commercial Nuclear Power: Prospects for the United States and the World. These projections are provided to the Office of Civilian Radioactive Waste Management (OCRWM) of DOE for use in estimating nuclear waste fund revenues, and to aid in planning the disposal of nuclear waste. In addition, the projections support other reports published annually by EIA such as Domestic Uranium Mining and Militing inciustry: Viability Assessment, and World Nuclear Fuel Cycle Requirements.
Pari of Another Model? No.

Model Interfaces: None.

\section{Sponsor:}

- Onice: Office of Integrated Analysis and Forecasting

- Division: Energy Supply and Conversion Division

- Branch: Nuclear and Electricity Analysis Branch, EI821

- Modei Contact: Mark Gielecki

- Telephone: 202-586-2276

Documentation:

- Energy Information Administration, Wines Model Documentation, DOE/EIA-M049 (Washington, DC, December 31, 1991).

- Energy Information Administration, Model Documentation of the World Integrated Nuclear Evaluation System, E.H. Pechan and Associates, (Washington, DC, June 1985).

- Volume 1, Model Documentation

- Volume 2, Model Description

- Volume 3, Executive Summary

- Energy Information Administration, Model Documentation of the World Integrated Nuclear Evaluation System, (Washington, DC, December 1984).

- Executive Summary

- Model Overview, Volume 1, DOE/EI/19656-1/1

- Model Description, Volume 2, DOE/EI/19656-1/2

- Data Documentation, Volume 3 Part A, DOE/EI/19656-1/3A

- Data Documentation, Volume 3 Part B, DOE/EI/19656-1/3B

- Model Abstract, Volume 4; DOE/EI/19656-1/4

- Energy Information Administration, World Integrated Nuclear Evaluation System (WINES) User's Guide and Model Documentation, MATHTECH, Inc. (Washington, DC, April 1983).

Archive Media and Installation Manual(s):

Last Model Update: December 1991. 
- WINES85 - for the report, Commercial Nuclear Power 1985

- WINES86 - for the report, Commercial Nuclear Power 1986

- WINES87 - for the report, Commercial Nuclear Power 1987

- WINE S88 - for the report, Commercial Nuclear Power 1988

- WINES89 - for the report, Commercial Nuclear Power 1989

- WINE S90 - for the report, Commercial Nuclear Power 1990

- WINES91 - for the report, Commercial Nuclear Power 1991

- WINE S91D - archived for purposes of documentation.

Purpose: The primary objective of WINES-PC is to project long-term annual nuclear generation and installed nuclear generating capacity world wide.

Energy System Described by Model: Estimates are made of country-specific economic growth rates, delivered energy demand growth rates, delivered energy demand, electricity generation, nuclear generation, and nuclear capacity.

\section{Coverage:}

- Geographic: Countries comprising the world outside of centrally planned economic areas with commercial nuclear programs.

- Time Unit/Frequency: WINES-PC is designed to forecast in five year intervals.

- Product(s): Gross domestic product or gross national product growth rates, aggregate delivered energy demand growth rate, aggregate delivered energy demand, electricity generation, nuclear generation, and nuclear capacity.

- Economic Sector(s): Country-specific aggregate demand.

\section{Modeling Features:}

- Model Structure: Basic four equations linked successively representing economic growth, aggregate energy demand growth, and electricity and nuclear generation requirements.

- Modeling Technique: Simulation based on long-term growth relationships and logistic market penetration functions. Economic growth rates based on labor supply and productivity growth rates, energy demand growth defined by a Cobb-Douglas demand function based on economic growth and aggregate energy price growth, and electricity and nuclear generation determined with logistic market penetration functions.

- Special Features: Long-term, highly aggregated model using logistic curves to estimate market penetration for electricity and nuclear generation.

\section{Non-DOE Input Sources:}

- Gregory Spencer, U.S. Department of Commerce, Bureau of the Census, Projections of the Population of the United States, by Age, Sex and Race: 1988 to 2080, Series P-25, No. 1018, Washington, DC, January 1989

- Labor-age population growth rates (U.S.)

- M.T. Vu, World Bank, Short-Term Population Projection, 1980 -2000 and Long-Tern Projection, 2000 to Stationary Stage by Age and Sex for All Countries of the World, Washington, DC, July 1984

- Labor-age population growth rates (foreign)

- World Bank, World Development Repont

- Classification of per capita income used to adjust price and income elasticities of energy demand over time (non-OECD nations)

- U.S. Department of Labor, Bureau of Labor Statistics, Employment and Eamings, Washington, DC, January 1991

- Labor force participation growth rate (U.S.)

- U.S. Department of Labor, Bureau of Labor Statistics, Handbook of Labor Statistics, (Washington, DC, various annual issues)

- Historical productivity data used to estimate labor productivity growth rate (U.S.)

- Organization for Economic Cooperation and Development, Department of Economics and Statistics, Labour Force Statistics, Paris, 1990

- Labor force participation growth rate (OECD nations)

- Organization for Economic Cooperation and Development, Historical Statistics-.OECD Economic Outlook, Paris (various annual issues)

- Labor productivity growth rate (OECD nations) 
- Historical energy prices used to estimate delivered energy price growth rate (OECD nations)

- Historical energy consumption, price and growth data used to estimate price and income elasticities of energy demand (OECD nations)

- Organization for Economic Cooperation and Development, Energy Prices and Taxes, Paris (various quarterly issues)

- Historical energy prices used to estimate delivered energy price growth rate (OECD nations)

- Historical energy consumption, price and growth data used to estimate price and income elasticities of energy demand (OECD nations)

- Organization for Economic Cooperation and Development, International Energy Agency, IEA Statistics: World Energy Statistics and Balances, Paris, June 1991

- Historical energy consumption, price and growth data used to estimate price and income elasticities of energy demand (OECD nations)

- Historical electrical and nuclear shares data used to estimate electrical and nuclear share asymptotic limits, and electrical and nuclear halving factors (foreign)

- Organization for Economic Cooperation and Development, International Energy Agency, Energy Policies and Programmes' of IEA Countries: 1989 Review, Paris, 1990

- Energy price forecasts used to estimate delivered energy price growth rate (OECD nations)

- Organization for Economic Cooperation and Development, Nuclear Energy Data, Paris, 1991

- Historical nuclear shares data and nuclear generation forecasts used to estimate nuclear share asymptotic limit and nuclear halving factor (foreign)

- Organization for Economic Cooperation and Development, Nuclear Energy Agency, Summary of Nuclear Power and Fuel Cycle Data in OECD Member Countries, Paris, March 1983

- Base year aggregate energy demand

- Organization for Economic Cooperation and Development, Nuclear Energy Agency, Tabulation of WPNFCR Questionnaire Responses from OECD Member Counities, Paris, Deccmber 1980

- Base year aggregate energy demand
- Organization for Economic Cooperation and Development, Nuclear Energy Agency, Tabulation of WPNFCR Questionnaire Responses from Non-OECD States, Paris, July 1980.

- Base year aggregate energy demand

- International Labour Office, Labour Force Estimates, Geneva, Switzerland, 1977.

- Labor force participation growth rate (nonOECD nations)

- Labor productivity growth rate (non-OECD nations)

- United Nations, 1981 Statistical Yearbook of the United Nations, New York, 1983

- Base year aggregate energy demand

- United Nations, 1980 Yearbook of World Energy Statistics, New York, 1982

- Base year aggregate energy demand.

DOE Data Input Sources:

Forms and Publications:

- Energy Information Administration, Annual Energy Outlook, DOE/EIA-0383 (Washington, DC, Annual)

- Energy price forecasts used to estimate delivered energy price growth rate (U.S.)

- Historical energy consumption, price and growth data used to estimate price and income elasticities of energy demand (U.S.)

- Base year aggregate energy demand

- Historical electrical and nuclear shares data used to estimate electrical and nuclear share asymptotic limits, and electrical and nuclear halving factors (U.S.)

- Energy Information Administration, Annual Energy Review, DOE/EIA-0384, (various issues) (Washington, DC, Annual)

- Historical energy prices used to estimate delivered energy price growth rate (U.S.)

- Historical energy consumption, price and growth data used to estimate price and income elasticities of energy demand (U.S.)

- Base year aggregate energy demand 
- Historical electrical and nuclear shares data used to estimate electrical and nuclear share asymptotic limits, and electrical and nuclear halving factors (U.S.)

- Energy Information Administration, Commercial Nuclear Power: Prospects for the United States and the World, DOE/EIA-0438, (Washington, DC, 1990 and 1991 issues)

- Historical nuclear shares data and nuclear generation forecasts used to estimate nuclear share asymptotic limit and nuclear halving factor (U.S.)

- Nuclear generation capacity factor

- Energy Information Administration, Improving Technology: Modeling Energy Futures forthe National Energy Strategy, Service Report, SR/NES/90-01, January 1991

- Energy price forecasts used to estimate delivered energy price growth rate (U.S.)

Models and Other:

- None.

General Output Descriptions: WINES-PC provides projections of both installed nuclear capacity and the intermediate variables necessary to project nuclear capacity by nation or aggregated by selected geographic and economic criteria. Output reports are created for two Reference case scenarios: an Upper (MID) Reference Case, and a Lower (LOW) Reference Case. Projections are generated for the following variables:

- GDP or GNP Growth Rate

- Delivered Energy Growth Rate
- Delivered Energy Demand

- Electrical Generation

- Nuclear Generation

- Nuclear Installed Capacity.

\section{Computing Environment:}

- Hardware Used: IBM compatible personal computer

- Operating System: MS DOS

- Language/S oftware Used: FORTRAN, Version 3.31

- Memory Requirement: $640 \mathrm{~Kb}$ RAM

- Storage Requirement: $600 \mathrm{~Kb}$

- Estimated Run Time: No longer than 5 minutes

- Special Features: None.

Independent Reviews Conducted:

- Independent Expert was conducted by James Quirk, Grantsburg, Wisconsin; April 1990.

- Model Quality Audit was conducted by the Office of Statistical Standards, April 1990.

- WINES Model Analysis, Decision Analysis Corporation of Virginia; Vienna, Virginia; August 1991.

- WINES Model Analysis (OECD Countries), Decision Analysis Corporation of Virginia; Vienna, Virginia; November 1991

Status of Evaluation Efforts by Sponsor: None. 
Appendix A

Major Modeling

Systems and

Contributing

Models 
Appendix A

\section{Major Modeling Systems and Contributing Models}

Gas Analysis Modeling System: (GAMS)

Production of Onshore Lower 48 Oil and Gas Model (PROLOG)

Intermediate Future Forecasting System: (IFFS)

(Supply Side)

Coal:

Coal Supply and Transportation Model (CSTM)

International Coal Trade Model (ICTM)

Resource Allocation and Mine Costing Model (RAMC)

Electric Utilities:

Electric Market Model (EMM)

Natural Gas and Oil:

Gas Analysis Modeling System (GAMS), including the Production of Onshore Lower 48 Oil and Gas Model (PROLOG)

Refinery:

Oil Market Module (OMM)

\section{Refinery Evaluation Modeling System: (REMS)}

Oil Refinery and Distribution Model

Refinery Yield Modeling System

\section{Revenue Requirements Modeling System: (RRMS)}

Revenue Requirements Model

Single Asset Model 
Appendix B
AEO 93
Forecasting System 


\section{Appendix B \\ AEO 93 Forecasting System}

The Energy Information Administration (EIA) projections presented in the Annual Energy Outlook 1993 (AEO93) were prepared using a collection of individual computer models that forecast annual production, supply, distribution, and consumption of energy for the United States. These models produce an integrated energy market forecast through the use of the Intermediate Future Forecasting System (IFFS). As a system, IFFS accounts for many interactions of the different segments of the energy industries and provides an internally consistent forecast of prices and quantities for which supply equals demand. 'This equilibrium solution accounts for the principal economic factors affecting energy supply and demand (including interfuel competition) and accounts for policies and regulations that cause departures from purely economic behavior.

In general, each of the supply models in the AEO93 Forecasting System determines the supply and delivered prices for each fucl, given the consumption levels projected by the demand models. The demand models compute consumption of each fucl, given the end-use prices of all competing fuels. The integrating methodology solves for the market equilibrium by balancing supply and demand for each fuel in every forecast year. Projections are generated through the year 2010. Paths for the price of crude oil on the world market and baseline macroeconomic forecasts are key exogenous assumptions to the AEO93 Forecasting System. The world oil price is derived from the Oil Market Simulation Model (OMS), which represents world oil demand and supply. Because OMS assumes that the Organization of Petroleum Exporting Countries (OPEC) remains the marginal supplier of crude oil, it computes the world oil price based on assumptions of OPEC productive capacity and nonOPEC production profiles.

Baseline macroeconomic projections are obtained by using the Data Resuurces, Inc. (DRI) Quarterly Model of the U.S. Economy, but introducing EIA forecasts of oil price. The basic DRI model also assumes a smoothly increasing path for world oil prices, but it is slightly different from the EIA path. The DRI model supplies the output of 11 major industrial sectors and 39 macroeconomic variables, including the real gross domestic product (GDP), the GDP price deflator, real disposable income and the interest rate on utility bonds; these values are all functions of delivered energy prices. Then, a macroeconomic module in the AEO93 Forecasting System revises those values, relative to the energy prices computed by the EIA modeling system--thus simulating the response of the DRI model to the EIA energy prices.

The Oil Market Module (OMM) represents the domestic refining and pricing of petroleum products and also computes the inport requirements for both crude oil and petroleum products. A set of econometric equations determines refinery gate prices for the major categories of petroleum products, based on the assumed world oil price and the product demand. Delivered prices to the end-use sectors are computed by adding markups based on historical data for distribution costs, State and Federal taxes, and the costs of environmental regulations, such as the Resource Conservation and Recovery Act of 1984, the Clean Air Act, and the Clean Air Act Amendinents of 1990.

The Coal Supply Transportation Model (CSTM) of IFFS determines the sources, distribution patterns, and minemouth and delivered prices of coal, representing a transportation network of 32 supply regions and 44 domestic demand regions. Projections of U.S. coal exports were developed with the International Coal Trade Model, which projects world coal flows from 20 export regions to 9 import regions. The coal supply curves for each of the $\mathbf{3 2}$ domestic supply regions were developed with the Resource Allocation and Mine Costing Model--based on mine costs by coal type and mining method, and on geologic and operating parameters of future mines.

The Gas Analysis Modeling System (GAMS) represents the domestic supply of natural gas, including imported and synthetic gas, and computes the average wellhead price as the market-clearing price in the United States. Delivered prices of natural gas are derived by ardding regional and sectoral markups to the wellhead price. For the electric utility sector, prices for both firm and interruptible customers are 


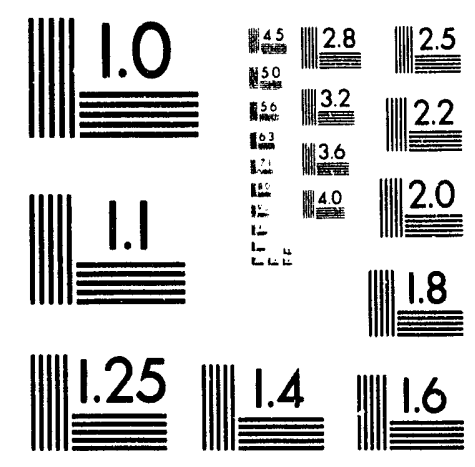



developed based on plant type. As a component of GAMS, the Production of Onshore Lower 48 Oil and Gas Model (PROLOG) calculates the domestic production of crude oil and natural gas, differentiating exploratory and developmental drilling activities. Imports of both Canadian and liquefied natural gas are explicitly represented, allowing for some expansion of current pipeline and terminal facilities.

The Electricity Market Module (EMM) represents the supply and price of electricity and computes the fuel requirements to generate electric power. A planning component determines the capacity expansion profiles of utilities, using a life-cycle cost methodology and assumptions of future fuel prices and electricity demand. A dispatch component allocates generation capacity to meet current demand by ranking the fuel and operating costs, subject to the constraints of the Clean Air Act Amendments. The financial component computes the price of electricity, accounting for all costs of construction and operation. Production of electricity by cogenerators and by independent and small power producers is forecast by the nonutility component, which competes with utility-generated electricity at the avoided cost of the utility sector.

Four end-use models calculate the consumption of each fuel in the residential, commercial, industrial, and transportation sectors as functions of price and macroeconomic variables. The residential and commercial sector models provide explicit represen- tations of the different technologies used to provide the various end-use services that consume energy in buildings, such as space heating and cooling, water heating, and lighting. The transportation sector model consists of four distinct segments: personal highway travel, freight travel, aviation travel, and "other" transportation. Fuel efficiencies, vehiclemiles traveled, and other variables associated with energy consumption for each transportation mode are incorporated in the model. The residential, commercial, and transportation models all make it possible to evaluate changes in capital equipment that are designed to conserve energy use. The industrial model is econometrically based; it computes fuel consumption by the manufacturing and nonmanufacturing sectors for heat and power, consumption of feedstocks as raw materials to the industrial sector, and other fuel consumption. In the manufacturing sector, the major energy- consuming industries are represented explicitly.

All models in the AEO93 Forecasting System use the most recently available data from EIA's supply and consumption surveys. A companion EIA report, $A$ ssumptions for the Annual Energy Outlook 1993, provides further information on the assumptions that underlie the $A E O 93$ forecasts, the models used to produce the forecasts, and changes made to these models specifically for $A E O 93$. That volume also provides references to the model documentation reports, which are available from the National Energy Information Center. 

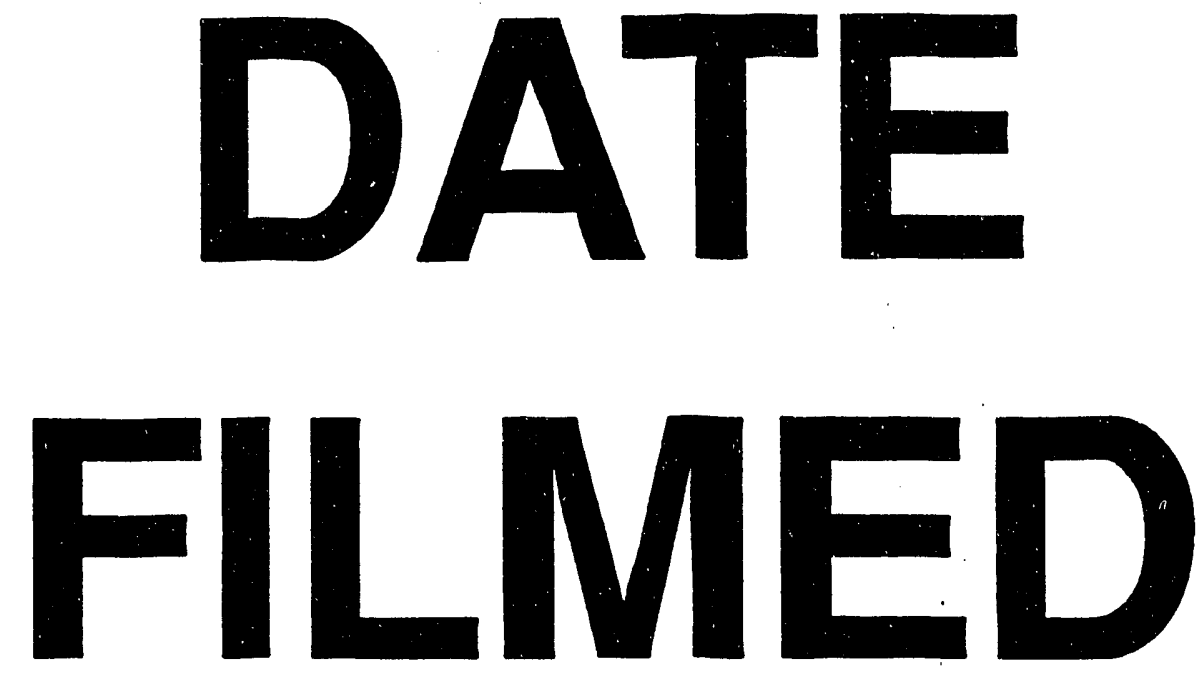

$9 / 29 / 93$
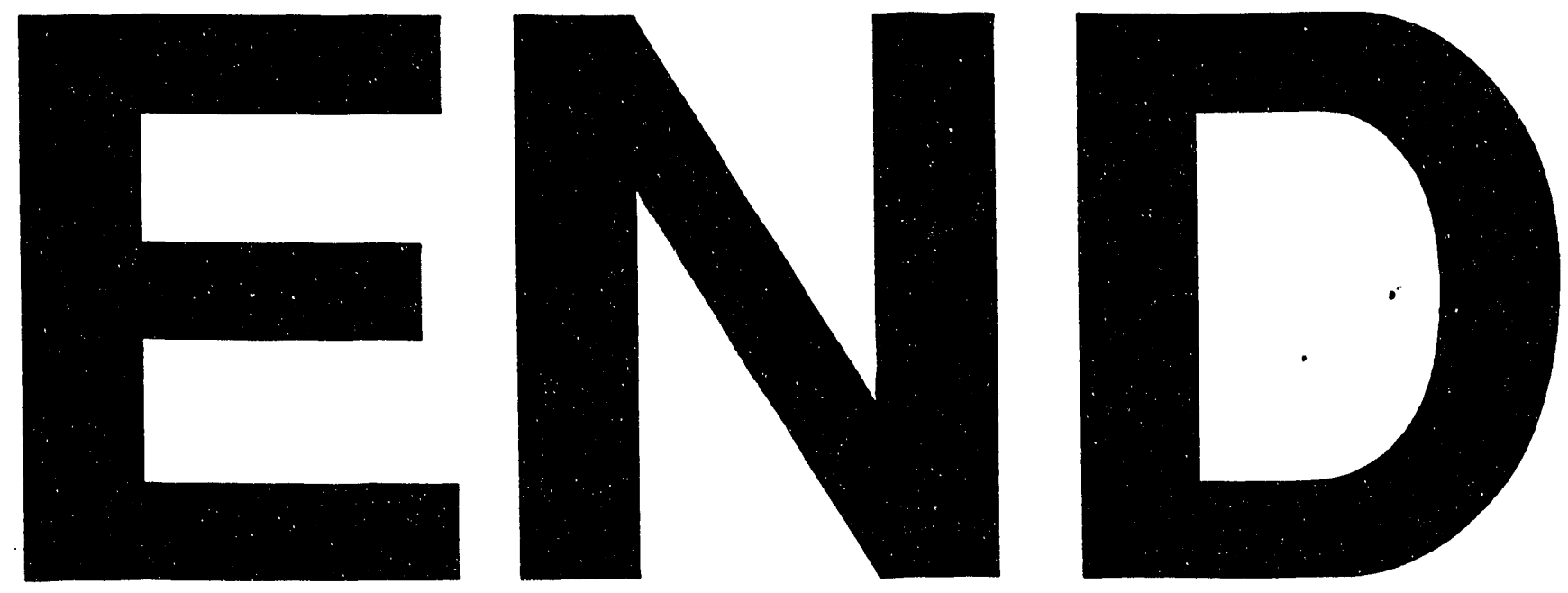
